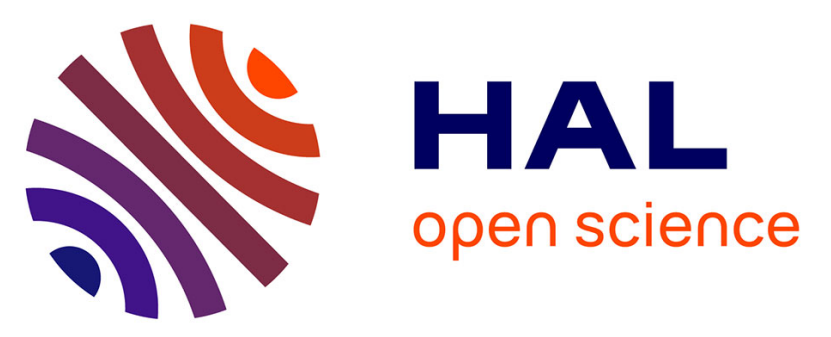

\title{
Overview of the French Operational Network for In Situ Observation of PM Chemical Composition and Sources in Urban Environments (CARA Program)
}

Olivier Favez, Samuel Weber, Jean-Eudes Petit, Laurent Alleman, Alexandre Albinet, Véronique Riffault, Benjamin Chazeau, Tanguy Amodeo, Dalia Salameh, Yunjiang Zhang, et al.

\section{To cite this version:}

Olivier Favez, Samuel Weber, Jean-Eudes Petit, Laurent Alleman, Alexandre Albinet, et al.. Overview of the French Operational Network for In Situ Observation of PM Chemical Composition and Sources in Urban Environments (CARA Program). Atmosphere, 2021, Air Pollution and Environment in France, 12 (2), pp.207. 10.3390/atmos12020207 . hal-03131288

\author{
HAL Id: hal-03131288 \\ https://hal.science/hal-03131288
}

Submitted on 4 Feb 2021

HAL is a multi-disciplinary open access archive for the deposit and dissemination of scientific research documents, whether they are published or not. The documents may come from teaching and research institutions in France or abroad, or from public or private research centers.
L'archive ouverte pluridisciplinaire HAL, est destinée au dépôt et à la diffusion de documents scientifiques de niveau recherche, publiés ou non, émanant des établissements d'enseignement et de recherche français ou étrangers, des laboratoires publics ou privés. 
Article

\title{
Overview of the French Operational Network for In Situ Observation of PM Chemical Composition and Sources in Urban Environments (CARA Program)
}

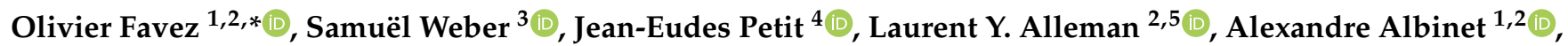 \\ Véronique Riffault ${ }^{2,5}{ }^{(0}$, Benjamin Chazeau ${ }^{6,7}{ }^{\circ}$, Tanguy Amodeo ${ }^{1,2}$, Dalia Salameh ${ }^{3}$, Yunjiang Zhang ${ }^{1,4}$, \\ Deepchandra Srivastava ${ }^{1}\left(\mathbb{D}\right.$, Abdoulaye Samaké ${ }^{3}$, Robin Aujay-Plouzeau 1,2, Arnaud Papin ${ }^{1}$, Nicolas Bonnaire ${ }^{4}$, \\ Carole Boullanger ${ }^{8}$, Mélodie Chatain ${ }^{9}$, Florie Chevrier ${ }^{10}$, Anaïs Detournay ${ }^{11}$, Marta Dominik-Sègue ${ }^{12}$, \\ Raphaële Falhun ${ }^{13}$, Céline Garbin ${ }^{14}$, Véronique Ghersi ${ }^{15}$, Guillaume Grignion ${ }^{16}$, Gilles Levigoureux ${ }^{17}$, \\ Sabrina Pontet ${ }^{18}$, Jérôme Rangognio ${ }^{19}$, Shouwen Zhang ${ }^{20}$, Jean-Luc Besombes ${ }^{21} \mathbb{D}_{\text {, Sébastien Conil }}{ }^{22}$, \\ Gaëlle Uzu ${ }^{3}{ }^{D}$, Joël Savarino ${ }^{3} \mathbb{D}$, Nicolas Marchand ${ }^{6}$, Valérie Gros ${ }^{4}$, Caroline Marchand ${ }^{1,2}$, Jean-Luc Jaffrezo ${ }^{3}$ \\ and Eva Leoz-Garziandia ${ }^{1,2}$
}

check for

updates

Citation: Favez, O.; Weber, S.; Petit, J.-E.; Alleman, L.Y.; Albinet, A.;

Riffault, V.; Chazeau, B.; Amodeo, T.; Salameh, D.; Zhang, Y.; et al.

Overview of the French Operational Network for In Situ Observation of PM Chemical Composition and Sources in Urban Environments (CARA Program). Atmosphere 2021, 12, 207. https://doi.org/10.3390/ atmos12020207

Academic Editor: Olivier Delhomme Received: 9 January 2021

Accepted: 30 January 2021

Published: 3 February 2021

Publisher's Note: MDPI stays neutral with regard to jurisdictional claims in published maps and institutional affiliations.

Copyright: (c) 2021 by the authors. Licensee MDPI, Basel, Switzerland. This article is an open access article distributed under the terms and conditions of the Creative Commons Attribution (CC BY) license (https:/ / creativecommons.org/licenses/by/ $4.0 /$ )
1 Institut National De L'environnement Industriel et Des Risques (INERIS), Parc Technologique Alata BP2, 60550 Verneuil-en-Halatte, France; alexandre.albinet@ineris.fr (A.A.); tanguy.amodeo@ineris.fr (T.A.); yunj_mail@163.com (Y.Z.); d.srivastava@bham.ac.uk (D.S.); robin.aujay-plouzeau@ineris.fr (R.A.-P.); arnaud.papin@ineris.fr (A.P.); caroline.marchand@ineris.fr (C.M.); eva.leoz@ineris.fr (E.L.-G.)

2 Laboratoire Central de Surveillance de la Qualité de l'Air (LCSQA), 60550 Verneuil-en-Halatte, France; laurent.alleman@imt-lille-douai.fr (L.Y.A.); veronique.riffault@imt-lille-douai.fr (V.R.)

3 Institut des Géosciences de l'Environnement (IGE, UMR 5001), CNRS, IRD, INP-G, Université Grenoble Alpes, 38000 Grenoble, France; samuel.weber@univ-grenoble-alpes.fr (S.W.); daliasalameh2013@gmail.com (D.S.); abdoulaye.samake2@univ-grenoble-alpes.fr (A.S.); gaelle.uzu@ird.fr (G.U.); joel.savarino@univ-grenoble-alpes.fr (J.S.); Jean-Luc.Jaffrezo@univ-grenoble-alpes.fr (J.-L.J.)

4 Laboratoire des Sciences du Climat et de l'Environnement (LSCE), CNRS-CEA-UVSQ (UMR 8212), 91191 Gif-sur-Yvette, France; jean-eudes.petit@lsce.ipsl.fr (J.-E.P.); nicolas.bonnaire@lsce.ipsl.fr (N.B.); valerie.gros@lsce.ipsl.fr (V.G.)

5 Center for Energy and Environment, Institut Mines-Télécom (IMT) Lille Douai, Université of Lille, 59000 Lille, France

6 Université Aix-Marseille, CNRS, LCE (UMR7376), 13007 Marseille, France; benjamin.chazeau@univ-amu.fr (B.C.); nicolas.marchand@univ-amu.fr (N.M.)

Atmo Sud, 13294 Marseille, France

Madininair, 97200 Fort-de-France, Martinique, France; carole.boullanger@madininair.fr Atmo Grand Est, 67300 Schiltigheim, France; melodie.chatain@atmo-grandest.eu

Atmo Nouvelle-Aquitaine, 33692 Mérignac, France; ffrancony@atmo-na.org

11 Atmo Bourgogne Franche-Comté, 25000 Besançon, France; anais.detournay@atmo-bfc.org

Atmo Normandie, 76000 Rouen, France; marta.dominik@atmonormandie.fr

Air Breizh, 35200 Rennes, France; rfalhun@airbreizh.asso.fr

Gwadair, 97170 Petit-Bourg, Guadeloupe, France; c.garbin@gwadair.fr

Airparif, 75004 Paris, France; Veronique.Ghersi@airparif.fr

16 Qualitair Corse, 20250 Corte, France; g.grignion@qualitaircorse.org

17 Air Pays de la Loire, 44300 Nantes, France; levigoureux@airpl.org

18 Atmo Auvergne Rhône-Alpes, 69500 Bron, France; SPontet@atmo-aura.fr

19 Lig'Air, 45590 Saint-Cyr-en-Val, France; rangognio@ligair.fr

20 Atmo Hauts de France, 59044 Lille, France; s.zhang@atmo-hdf.fr

21 CNRS, EDYTEM (UMR5204), Université Savoie Mont-Blanc, 73000 Chambéry, France; jean-luc.besombes@univ-smb.fr

22 ANDRA, DRD/GES Observatoire Pérenne de l'Environnement, 55290 Bure, France; Sebastien.Conil@andra.fr

* Correspondence: olivier.favez@ineris.fr

Abstract: The CARA program has been running since 2008 by the French reference laboratory for air quality monitoring (LCSQA) and the regional monitoring networks, to gain better knowledge-at a national level—on particulate matter (PM) chemistry and its diverse origins in urban environments. It results in strong collaborations with international-level academic partners for state-of-the-art, straightforward, and robust results and methodologies within operational air quality stakeholders (and subsequently, decision makers). Here, we illustrate some of the main outputs obtained over the 
last decade, thanks to this program, regarding methodological aspects (both in terms of measurement techniques and data treatment procedures) as well as acquired knowledge on the predominant PM sources. Offline and online methods are used following well-suited quality assurance and quality control procedures, notably including inter-laboratory comparison exercises. Source apportionment studies are conducted using various receptor modeling approaches. Overall, the results presented herewith underline the major influences of residential wood burning (during the cold period) and road transport emissions (exhaust and non-exhaust ones, all throughout the year), as well as substantial contributions of mineral dust and primary biogenic particles (mostly during the warm period). Long-range transport phenomena, e.g., advection of secondary inorganic aerosols from the European continental sector and of Saharan dust into the French West Indies, are also discussed in this paper. Finally, we briefly address the use of stable isotope measurements $\left(\delta^{15} \mathrm{~N}\right)$ and of various organic molecular markers for a better understanding of the origins of ammonium and of the different organic aerosol fractions, respectively.

Keywords: France; urban air quality; aerosol chemical composition; source apportionment; monitoring strategies

\section{Introduction}

Due to their adverse health effects, and their environmental, economic, and climatic impacts, airborne particles are the subject of great concern within the scientific community [1-6]. For the same reasons, they are also gaining large attention from the public, the media, and some decision makers. In this context, regulations take place in most countries across the world in order to reduce their emissions and monitor their loadings in ambient air. In the European Union (EU), directives 2004/107/EC and 2008/50/EC (recently amended by directive 2015/1480/EC) are defining the framework for the control of air pollution, notably setting recommendations for in situ measurements of mass concentrations of $\mathrm{PM}_{10}$ and $\mathrm{PM}_{2.5}$ in ambient air (particulate matter (PM) with an aerodynamic diameter smaller than 10 and $2.5 \mu \mathrm{m}$, respectively). In France, regional air quality monitoring networks (AASQAs) are responsible for applying these recommendations under the supervision of the Ministry of Environment (currently named MTE), which is responsible for setting the strategies to implement EU directives at the national scale. Meanwhile, the French reference laboratory for air quality monitoring (LCSQA) is providing technical and scientific support to both the MTE and AASQAs.

EU regulations impose different limit values to be fulfilled for PM concentration levels, notably based on their annual-mean values $\left(40 \mu \mathrm{g} / \mathrm{m}^{3}\right.$ for $\mathrm{PM}_{10}$ and $25 \mu \mathrm{g} / \mathrm{m}^{3}$ $\left.\mathrm{PM}_{2.5}\right)$, on the number of exceedances of a daily-mean threshold $\left(50 \mu \mathrm{g} / \mathrm{m}^{3}\right.$ not to be exceeded more than 35 days per year for $\mathrm{PM}_{10}$ ), and on a 3-year moving averaged value for $\mathrm{PM}_{2.5}$ urban background level at the national scale (the average exposure index, with a decreasing trend to be achieved over time). These limit values are still substantially higher than target values recommended by the World Health Organization (e.g., $20 \mu \mathrm{g} / \mathrm{m}^{3}$ and $10 \mu \mathrm{g} / \mathrm{m}^{3}$, respectively, for $\mathrm{PM}_{10}$ and $\mathrm{PM}_{2.5}$ annual-mean values, and no more than 3 exceedances per year of the daily thresholds of $50 \mu \mathrm{g} / \mathrm{m}^{3}$ for $\mathrm{PM}_{10}$ and of $25 \mu \mathrm{g} / \mathrm{m}^{3}$ for $\mathrm{PM}_{2.5}$ ). Nevertheless, they were frequently exceeded in France, as in many European countries, by the time directive 2008/50/EC entered into force. For instance, 33 French urban areas did not comply with $\mathrm{PM}_{10}$ limit values in 2010 [7]. Although numerous air quality action plans have been implemented at the local scale, and significant improvement could be observed over the last decade (e.g., only two urban areas exceeded these limit values in 2019), France still currently faces decisions of the European Commission, to be brought to the EU Court of Justice, regarding poor air quality due to high $\mathrm{PM}_{10}$ levels (as well as nitrogen dioxide).

Designing air pollutant emission abatement strategies and evaluating their efficiencies require sound knowledge of the main PM origins. This includes appropriate measurements 
of their chemical properties. Indeed, airborne particles are composed of a large variety of chemical species, reflecting the wide diversity of their emission sources and of their (trans-)formation processes in the atmosphere. However, only a few chemical species are regulated under directive 2008/107/EC, considering their known toxicity: lead, cadmium, nickel, arsenic, and polycyclic aromatic hydrocarbons (PAHs, with benzo(a)pyrene considered as representative of their mixture in ambient air). These species account for a very small fraction of PM, while others are found in a much higher abundance and could provide information on their origins. This is notably the case of the PM carbonaceous fractions-namely elemental and organic carbon (EC and OC, respectively) - as well as some water-soluble inorganic species, including nitrate $\left(\mathrm{NO}_{3}{ }^{-}\right)$, sulfate $\left(\mathrm{SO}_{4}{ }^{2-}\right)$, ammonium $\left(\mathrm{NH}_{4}{ }^{+}\right)$, chloride $\left(\mathrm{Cl}^{-}\right)$, sodium $\left(\mathrm{Na}^{+}\right)$, and calcium $\left(\mathrm{Ca}^{2+}\right)$ [8]. Moreover, the contribution of these species to $\mathrm{PM}_{2.5}$ shall be monitored at a few remote stations of EU member states-with no fixed limit nor target value as yet-according to directive 2008/50/CE (1 site per 100,000 $\mathrm{km}^{2}$ in each country). This requirement has been elaborated to better assess transboundary air pollution phenomena, complementary to the co-operative program of the long-range transmission of air pollutants in Europe, also known as the European Monitoring and Evaluation Programme (EMEP, www.emep.int, [9,10]), under the Convention on Long-Range Transboundary Air Pollution (CLRTAP). This policy-driven program was complemented with various research projects at the European scale in the last decades, notably leading to the current establishment of the Aerosol, Clouds and Trace gases Research Infrastructure (ACTRIS, www.actris.eu [11,12]). However, these initiatives are still mainly focused on background air pollution at a regional (or larger) scale, rather than on hotspots for population exposure to poor air quality (i.e., urban and/or heavily industrialized areas).

In this context, LCSQA has been implementing, together with the MTE and AASQAs, an ambitious operational network for in situ observation of urban PM chemical composition and sources (the CARA program, www.lcsqa.org/fr/le-dispositif-cara) since 2008 [13], with the following objectives:

- Document the chemistry and main sources of PM pollution events;

- Investigate peculiarities possibly leading to local $\mathrm{PM}_{10}$ threshold exceedances;

- Achieve long-term ( $\geq 1$ y) source apportionment studies at various locations;

- Provide datasets useful for the validation of chemical transport models (CTMs);

- Trigger and / or support further research activities for a better knowledge on air quality fundamentals.

These objectives, as well as related experimental strategies, are refined yearly to try to accommodate the needs of the MTE and AASQAs.

The present paper aims to describe the overall organization and activities of the CARA program, as well as illustrate and/or summarize some of the main findings from the last decade. After a brief description of the methodologies in use, it presents major results obtained from some inter-laboratory comparison exercises, which are essential for data quality assurance and quality control in networking activities. A general picture of the PM chemical composition, as obtained by the measurements of its main constituents, is then proposed, after discussing in more detail the prevalent primary PM sources that have been investigated, so far, in the frame of the CARA program, namely residential wood burning, road transport, primary biogenic particles, sea salts, and Saharan dust. Finally, we address the main origins of the secondary aerosols (formed in the atmosphere through oxidation processes and interactions with the gaseous phase), impacting French urban environments, i.e., ammonium nitrate, ammonium sulfate, and secondary organic aerosols (SOA).

\section{Experimental}

\section{1. $P M_{10}$ Sampling Network}

The list of past and current sampling stations included in the CARA program is given in Table A1 (Appendix A). These stations mainly correspond to (peri-)urban background stations, with, however, a few traffic or rural background sites. Except for specific measurement 
campaigns, most of these sites were operated for quasi-continuous sampling over several years. The oldest ones - namely in Bordeaux, Lyon, Grenoble, Rouen, Strasbourg, and Revinhave been collecting $\mathrm{PM}_{10}$ filter samples for more than 10 years. Here, results obtained from this dense observation network are supplemented by complementary results acquired during a specific pluriannual research program focusing on air pollution sources and mechanisms in the Arve Valley of the French Alps (DECOMBIO, [14,15]). Data collected at the remote regional background site of the long-term Environmental Observatory (OPE, [16,17])—maintained by the agence nationale pour la gestion des déchets radioactifs (ANDRA) — has also been added for purposes of comparison with results from urban environments.

Particles are collected onto quartz fiber filters (Whatman QM-A in 2008-2010, and Pallflex TissuQuartz from 2010 onwards), pre-fired during $24 \mathrm{~h}$ at $500{ }^{\circ} \mathrm{C}$ before use, to lower filter blank values (especially for organic carbon concentrations). Filters are mainly collected by AASQAs, following the requirements of the EN 12341 European standard, using sequential high-volume samplers (typically, DAH-80 models, Digitel, running at a flow rate of $30 \mathrm{~m}^{3} / \mathrm{h}$ ), except for some intensive campaigns using low-volume samplers (e.g., Partisol 2025 model, Thermo, $1 \mathrm{~m}^{3} / \mathrm{h}$, or SEQ47 model, Leckel, $2.3 \mathrm{~m}^{3} / \mathrm{h}$ ). Quasi-continuous sampling is commonly performed in synergy with regulatory offline monitoring of PAHs, with continuous sampling of daily filters alternating between the latter measurements (every third or sixth day) and the CARA program filter collection (all the other days). Sampled filters are returned from the station and then commonly sent to Ineris (or IGE, for Alpine and southeastern sites) within cool boxes, and finally stored in freezers (below $-10{ }^{\circ} \mathrm{C}$ ).

Only a small fraction (15-20\%) of the collected filters is actually analyzed for its chemical composition, fitting the objectives described above. Examples of chemical analyses that have been performed in the frame of the CARA program can be found for instance in [18]. Each filter chemical analysis includes the measurement of the carbonaceous fractions-i.e., organic and elemental carbon (OC and EC) - as well as the main anions and cations (nitrate: $\mathrm{NO}_{3}{ }^{-}$, sulfate: $\mathrm{SO}_{4}{ }^{2-}$, chloride: $\mathrm{Cl}^{-}$, ammonium: $\mathrm{NH}_{4}{ }^{+}$, sodium: $\mathrm{Na}^{+}$, potassium: $\mathrm{K}^{+}$, magnesium: $\mathrm{Mg}^{2+}$, and calcium: $\mathrm{Ca}^{2+}$ ), as featuring major aerosol chemical species found in European ambient air, namely soot, organic matter, ammonium nitrate, ammonium sulfate, sea salt, and mineral dust [8]. OC-EC analyses are performed following the EN 16909 European standard thermo-optical method (in transmission mode), using the socalled EUSAAR-2 protocol [19]. Anions and cations are measured by ion chromatography (IC), after extraction of filter sample punches in ultra-pure water and applying recommendations of the EN 16913 European standard. These IC analyses also allow for the quantification of some organic species, such as oxalate and methanelsulfonic acid (MSA). Water-soluble sample extracts obtained from this analytical procedure are also commonly used for the measurement of some anhydrosugars, considered as molecular markers of biomass burning emissions, including levoglucosan and its isomers, or sugars and sugar alcohol (glucose, mannitol, arabitol, and sorbitol-the last three often being referred to as polyols), considered as indicators of primary biogenic emissions, using ion chromatography or high performance liquid chromatography, followed by pulsed amperometric detection (IC- or HPLC-PAD). More recently, efforts have also been put in the measurements of cellulose, as a proxy of plant debris within the $\mathrm{PM}_{10}$ fraction [20]. For source apportionment purposes, the elemental composition (starting from sodium atomic mass) is additionally measured by inductively coupled plasma mass-or atomic emission-spectrometry (ICP-MS or ICP-AES) following sample preparation and analytical procedures defined by the EN 14902 European standard. Finally, various other analytical techniques, including liquid or gas chromatography, coupled with mass spectrometry (LC or GC-MS), have also been used for a better apportionment of the organic aerosol fractions (e.g., [18,20-23]).

Chemical analyses are conducted by Ineris and Institut Mines Telecom (IMT) Lille Douai as part of the LCSQA, as well as by academic partners (mostly IGE and LSCE). These laboratories regularly participate in inter-laboratory comparison (ILC) exercises at an international level, such as those performed in the frame of the European Committee 
of standardization (CEN), EMEP, ACTRIS, and/or Global Atmosphere Watch (GAW) programs (e.g., [24]).

When using high-volume samplers, large circular filters $(15 \mathrm{~cm}$ total diameter, corresponding to a sampled surface area of about $154 \mathrm{~cm}^{2}$ ) are collected, so that leftover filter surfaces generally remain available after sub-sampling for completion of the analyses mentioned above. These remaining filter parts are saved in freezers, with non-analyzed filters, contributing to enlarge the wide sets of $\mathrm{PM}_{10}$ samples that can be made available for possible further analyses (e.g., for oxidative potential measurements [25], or investigation of the links between PM chemistry and microbiology, [26]).

\subsection{Online Monitoring Network}

In such a sampling network, filter collection and transportation, followed by subsequent offline chemical speciation and data treatment, can be achieved within a relatively short timeframe (e.g., down to 3 days, [27]), but do not allow for the assessment of the nature of aerosol pollution episodes in near real-time. Moreover, albeit allowing for extensive characterization of the PM chemistry at the molecular level, documentation of seasonal and interannual variabilities at multiple sites using such a methodology is labor-intensive and costly on the long-term basis. To tackle these issues, online and continuous measurements shall be envisaged, using simple but robust technologies. In this context, the LCSQA/Ineris started to evaluate and implement instrumental candidates for in situ automatic measurements of the aerosol chemical composition in the early 2010s, in collaboration with LSCE. In particular, two instruments appeared to be well-suited for these purposes [28,29]: the multi-wavelength aethalometer (AE33 model, Magee Scientific) and the aerosol chemical speciation monitor (ACSM, Aerodyne Res. Inc., Billerica, MA, USA), which are briefly described hereafter.

A full description of the AE33 measurement principle is available elsewhere [30,31]. Briefly, this instrument allows for the determination of the aerosol light absorption coefficients at seven different wavelengths (370, 470, 520, 590, 660, 880, and $950 \mathrm{~nm})$. Ambient concentrations of equivalent black carbon $(\mathrm{eBC})$ are then estimated using data obtained at $880 \mathrm{~nm}$ and assumptions on BC mass absorption efficiency (MAE). Multi-wavelength measurements also allow for the discrimination between the two main $\mathrm{BC}$ sources, i.e., liquid fuel burning and solid fuel burning, using the Aethalometer model [32]. eBC concentrations - as well as its source apportioned fractions (named here by convention $\mathrm{eBC}_{\mathrm{ff}}$ and $\mathrm{eBC} \mathrm{wb}_{\mathrm{wb}}$ for liquid and solid fuel emissions, respectively) - which are presented and discussed in the present paper were obtained in the $\mathrm{PM}_{2.5}$ fraction, using the default calculation parameters proposed by the manufacturer.

The ACSM was designed to provide continuous measurements of the main nonrefractory chemical species within submicron aerosols [33]. It is based on a less advanced but more robust technology than aerosol mass spectrometry (AMS), nowadays widely used for state-of-the-art research experiments in atmospheric science. Briefly, fine aerosols are sampled into the ACSM system through a critical orifice and an aerodynamic lens, allowing to focus them - under high vacuum - onto a vaporizer usually heated at a temperature of about $600^{\circ} \mathrm{C}$. Vaporized molecular fragments can then be detected using electron impact $(70 \mathrm{eV})$ ionization mass spectrometry. Each ACSM operated in the frame of the CARA program has been equipped with a $\mathrm{PM}_{1}$ aerodynamic lens. Measured species notably include organic aerosols (OA), nitrate, sulfate, ammonium, and chloride. The determination of their ambient mass concentrations requires cautious calibrations of the instrument response factor and relative ion efficiency [34], which are predominantly performed together with the LCSQA. The consistency of these ACSM measurements at the national level is further assessed by regular participation to ILC exercises organized by the aerosol chemical monitor calibration center (ACMCC), as a unit of the ACTRIS topical center for aerosol in situ measurements (see Section 3.3).

The combination of AE33 and ACSM measurements is then allowed to determine both the refractory and non-refractory major chemical species within the fine aerosol 
mode. Following successful evaluation of the operability of this monitoring strategy at the ACTRIS-SIRTA [28], it could be applied to selected urban background stations operated by AASQAs. This deployment has gradually been achieved since then, leading to a current number of 12 stations being equipped with AE33 and ACSM in the frame of the CARA program (Table A1 and Figure 1). Besides SIRTA, 10 of these sites are part of 7 different AASQAs and the twelfth one corresponds to a new ACTRIS site operated by IMT Lille Douai in Lille.

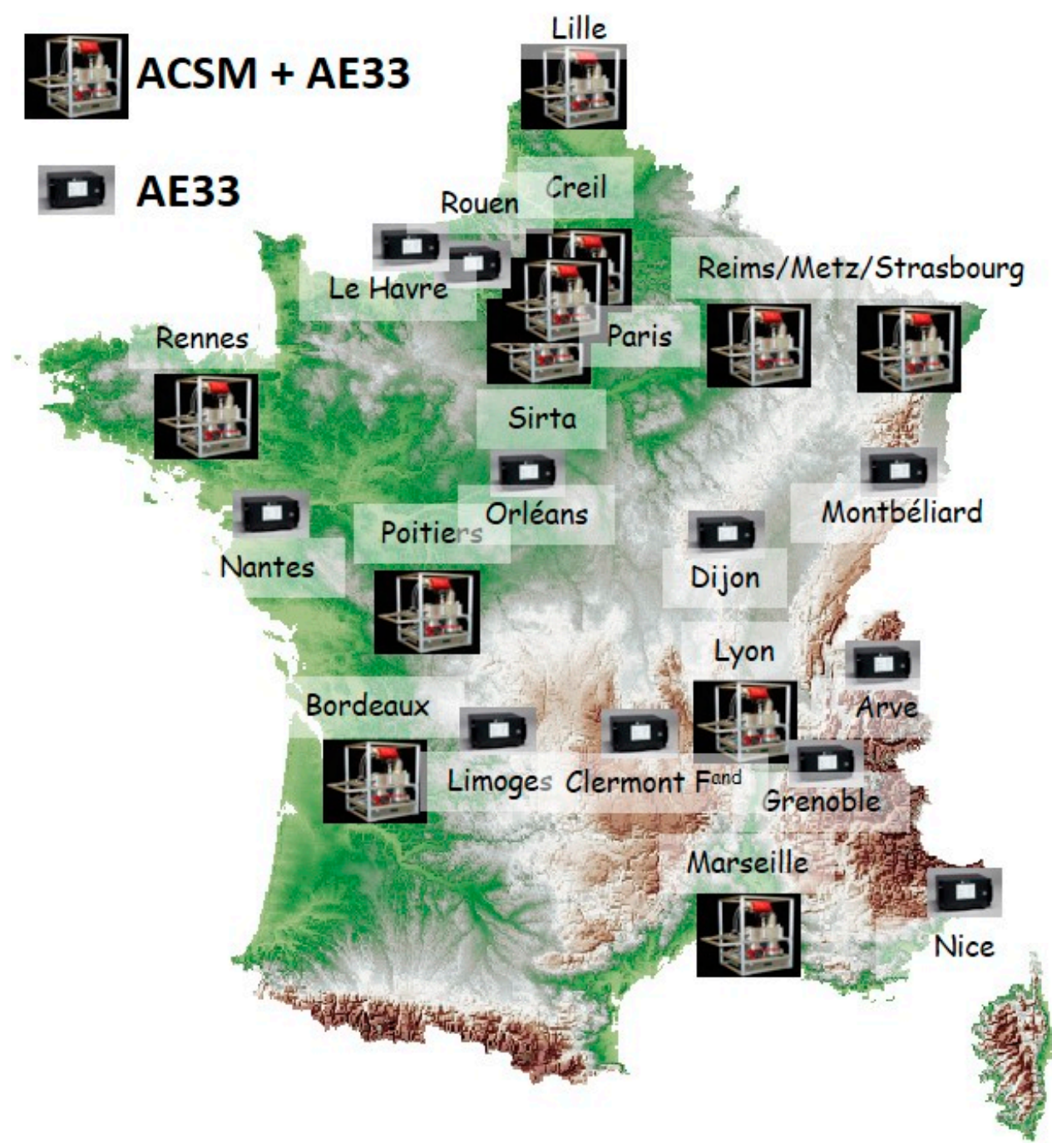

Figure 1. Spatial distribution of the main sites of the CARA program equipped with aerosol chemical speciation monitor (ACSM) and AE33, or with AE33 only (non-exhaustive), in 2020.

The current distribution of sites equipped with both ACSM and AE33 devices offers a relatively dense covering of the French metropolitan area. Considering the investment costs associated with ACSM equipment, and that it measures species, displaying rather homogeneous background concentration at a regional scale, this ACSM network nowadays offers a very close-to-optimum number of sites. In contrast to ACSM, AE33 measures primary species, which can have a larger spatial heterogeneity, so that additional urban areas can be equipped with AE33 only (Table A1 and Figure 1).

The LCSQA coordinates the quality assurance and quality control (QA/QC) strategy related to this operational online monitoring program. This notably includes calibration of ACSM devices (as mentioned above), production, and dissemination of guidelines and standard operating procedures (for both ACSM and AE33), training sessions, and ILC organization (see next sub-section). In return, feedback and expertise brought back 
on a regular basis by the AASQAs, by the manufacturers and the French ACSM seller (ADDAIR), ensure lively dissemination of the information between the CARA program partners and efficient improvement of the QA/QC protocols and procedures.

\subsection{Data Processing}

At the European level, $\mathrm{PM}_{10}$ is known to be generally and predominantly composed of carbonaceous matter, i.e., elemental carbon (EC) and organic matter (OM), and inorganic matter, notably including nitrate, sulfate, ammonium, sea salts, and mineral dust [8]. With extremely rare exceptions, each site of the CARA program is equipped with $\mathrm{PM}_{10}$ (and also often $\mathrm{PM}_{2.5}$ ) automated measurement systems, so that quality control of the chemical speciation datasets includes systematic chemical mass closure exercises [35], where the sum of major components (typically, $\mathrm{PM}_{\text {chem }}=\mathrm{EC}+\mathrm{OM}+$ nitrate + sulfate + ammonium + sea salts + mineral dust) is validated by comparison with regulatory $\mathrm{PM}_{10}$ measurements performed by the AASQAs (e.g., [36]).

For further investigation of the PM sources, receptor models are nowadays widely used in atmospheric sciences. In particular, a growing number of studies have been applying positive matrix factorization (PMF, [37]) to chemically speciated datasets over the last decade (e.g., [38-40]). PMF is a multivariate tool that makes use of measured concentrations and their uncertainties to solve the mass balance equation $X=G \times F+E$, where $X$ corresponds to the input data matrix, F represents a matrix whose vectors stand for the profiles of a p number of factors (that might eventually be attributed to specific emission sources or secondary aerosol types), $\mathrm{G}$ corresponds to the contributions of the $\mathrm{p}$ sources to total PM, and E represents the residual matrix. Detailed and practical descriptions of the way PMF has been used in the frame of the CARA program, and this program, participate in the development of receptor models, and can be found elsewhere [18,36,41-43]. All of the PMF results presented in this paper were obtained using the most recent US EPA PMF v5.0 software and following recommendations of the EU guidance document [44].

Source apportionment of PM in near real-time is a tremendous challenge. ACSM (and AMS) measurements commonly allow for discriminating between different types of submicron organic aerosols, based on PMF approaches applied to OA mass spectra $([45,46])$. Despite recent advances and current developments towards automatic source apportionment analysis [47], applying receptor models on ACSM datasets is still highly labor-intensive. Moreover, while outputs are quite interesting for atmospheric sciences, they might be misleading for the general public and policy makers when trying to link OA components and actual emission sources (e.g., [48,49]). For these reasons, the application of near-real time source apportionment of ACSM datasets, within such a network as the CARA program, requires further extensive research and harmonization efforts (see also Sections 5 and 12).

By contrast, AE33 can provide direct information on solid fuel and liquid fuel combustions. Indeed, for French urban environments, $\mathrm{eBC}_{\mathrm{ff}}$ has been shown to be predominantly related to road transport emissions, while $\mathrm{eBC}_{\mathrm{wb}}$ mainly originates from wood burning for residential heating in cold seasons $[50,51]$. These fractions can then be used to estimate PM loadings that may be attributable to both sources (i.e., $\mathrm{PM}_{\mathrm{ff}}$ and $\mathrm{PM}_{\mathrm{wb}}$, respectively), using conversion factors, such as: $\mathrm{PM}_{\mathrm{ff}}=a \times \mathrm{eBC}_{\mathrm{ff}}$ and $\mathrm{PM}_{\mathrm{wb}}=b \times \mathrm{eBC}_{\mathrm{wb}}$, where $a$ and $b$ can be retrieved from the literature and/or further site-specific a priori knowledge. In practice, $a$ is considered here as constant over the metropolitan territory (with $a=2$, roughly corresponding to OC/EC ratio of $0.5-0.6$ and hydrocarbon-like organic aerosol O-to-C ratio of 1.2-1.4 within vehicular exhaust $[52,53])$, whereas fit-for-purpose $b$ values have been determined at each site through comparisons with independent offline filter-based source apportionment analyses $[41,54]$. For stations where no independent source apportionment study allowed to determine a site-specific $b$ value, the LCSQA currently recommends to AASQAs estimating wintertime $\mathrm{PM}_{\mathrm{wb}}$ from AE33-based brown carbon measurement and using a constant conversion factor, as explained in $[55,56]$. We do not pretend in this paper that these simple calculations could be accurately applied in other countries, and overall 
uncertainties of approximately $30-40 \%$ can be considered here for $\mathrm{PM}_{\mathrm{ff}}$ and $\mathrm{PM}_{\mathrm{wb}}$ loading estimates. Yet, they proved to compare well with independent methods (examples given for $\mathrm{PM}_{\mathrm{wb}}$ in Section 5) and offer very useful information to AASQAs in near-real time, especially during pollution episodes (Section 4.3). Finally, it shall also be noted that $\mathrm{PM}_{\mathrm{ff}}$ do not include non-exhaust vehicular emissions nor the influence of tailpipe emissions on the formation of secondary aerosols from gaseous precursor emissions (e.g., volatile organic compounds (VOCs), $\mathrm{NO}_{\mathrm{x}}$ and $\mathrm{NH}_{3}$ ), whose influence on $\mathrm{PM}$ cannot be assessed in near-real time.

The next data treatment step, currently under investigation at some of the CARA supersites, is the combination between $\mathrm{PM}_{\mathrm{ff}}$ and $\mathrm{PM}_{\mathrm{wb}}$ with ACSM chemical species concentrations to refine the identification of the fine aerosol mode main components within $\mathrm{PM}_{10}$. To do so, ammonium nitrate and ammonium sulfate concentrations are estimated based on ACSM measurements, assuming that molecular stoichiometry between nitrate and ammonium, and between sulfate and ammonium is respected. Then, considering that most of the ammonium sulfate, ammonium nitrate, and secondary organic aerosols are mainly present in the $\mathrm{PM}_{2.5}$ fraction, it is possible to extrapolate the ACSM data (in $\mathrm{PM}_{1}$ ) to deduce a concentration of these latter species in the $\mathrm{PM}_{10}$ fraction. This is done by multiplying the ACSM concentrations by the $\mathrm{PM}_{2.5} / \mathrm{PM}_{1}$ ratio measured online by a FIDAS instrument (based on an optical particle spectrometer, PALAS). The concentrations of ammonium nitrate and ammonium sulfate in $\mathrm{PM}_{10}$ are then assumed equal to their loadings estimated in this way. In parallel, secondary organic aerosols (SOA) present in $\mathrm{PM}_{2.5}$ are obtained from the difference between total OA concentrations calculated in $\mathrm{PM}_{2.5}$ and primary organic aerosol contributions assessed to be contained within $\mathrm{PM}_{\mathrm{ff}}$ and $\mathrm{PM}_{\mathrm{wb}}$. Using such a methodology, chemically-speciated $\mathrm{PM}_{2.5}$ components, as well as coarse mode aerosols (corresponding to the difference between $\mathrm{PM}_{10}$ and $\mathrm{PM}_{2.5}$ ), can be plotted in a single graph (see Section 4.3) in real-time, which again provides, as a first approach, useful information to AASQAs and decision makers during PM pollution episodes.

\section{Inter-Laboratory Comparisons (ILC) Exercises}

For QA/QC purposes, the laboratories involved in the CARA program not only participate in ILCs, but also co-organize some of them at the national and international levels (e.g., starting with EC-OC thermo-optical methods, [57]). During these ILCs, a statistical analysis is generally performed, in accordance with the EN ISO/CEI 17043 standard. For this analysis, the analytical or measurement performances are evaluated using the Z-score calculated as follows:

$$
z_{i}=\frac{\overline{x_{i}}-x^{*}}{\hat{\sigma}}
$$

where $Z_{i}$ is the $Z$ score obtained by instrument $i, x_{i}$ is the mean of the measurements performed by instrument $i, x^{*}$ is the robust mean of all the instruments participating in the ILC, and $\sigma^{\wedge}$ is the standard deviation of fitness estimated from the entire dataset. It is generally accepted that a Z-score between -2 and +2 is indicative of good performance while a Z-score below -2 or above +2 raises questions about accuracy of the analytical procedures or the proper functioning of the online instrument.

Hereafter, we provide examples of results obtained during three ILCs, focusing on different types of measurements, namely levoglucosan (and isomers) offline analyses, as well as AE33 and ACSM online measurements.

\subsection{Levoglucosan}

Levoglucosan is known as a tracer for biomass burning aerosols [58], and has been widely used to estimate the concentration of organic matter related to this emission source by applying a multiplicative conversion factor [59]. Its accurate quantification is then critical to avoid significant bias when using such a mono-tracer method. In this context, LCSQA and IGE organized an ILC dedicated to the measurement of this compound and its 
isomers (mannosan and galactosan), including results obtained by 13 European research laboratories [60]. The main purpose of this ILC was to evaluate the analytical repeatability and reproducibility standard deviations obtained by the participants using their own analytical method. Four test materials were sent to the participants, including two ambient air filter samples (corresponding to high winter range concentrations), one laboratory blank filter, and one certified reference material (SRM 1649b, urban dust, National Institute of Standards and Technology (NIST)). Most of the participants obtained satisfactory Zscores $(-2<Z$-score $<+2)$. Furthermore, the analytical procedure used by participants appeared to have no significant influence on the quantification of levoglucosan and its isomers, and relatively low expanded uncertainties could then be calculated (e.g., 35-52\% for levoglucosan). Results from this ILC also provided a robust concentration value of levoglucosan (177.0 $\mathrm{\mu g} \mathrm{g}^{-1}$ with 52\% expanded uncertainty) and its isomers for the SRM $1649 \mathrm{~b}$ (Figure 2), consistent with previous values available in the literature (e.g., [61]). Finally, the use of cost-effective amperometry-based methodologies, which were developed in the early 2010s, and could be validated for application within the CARA program.

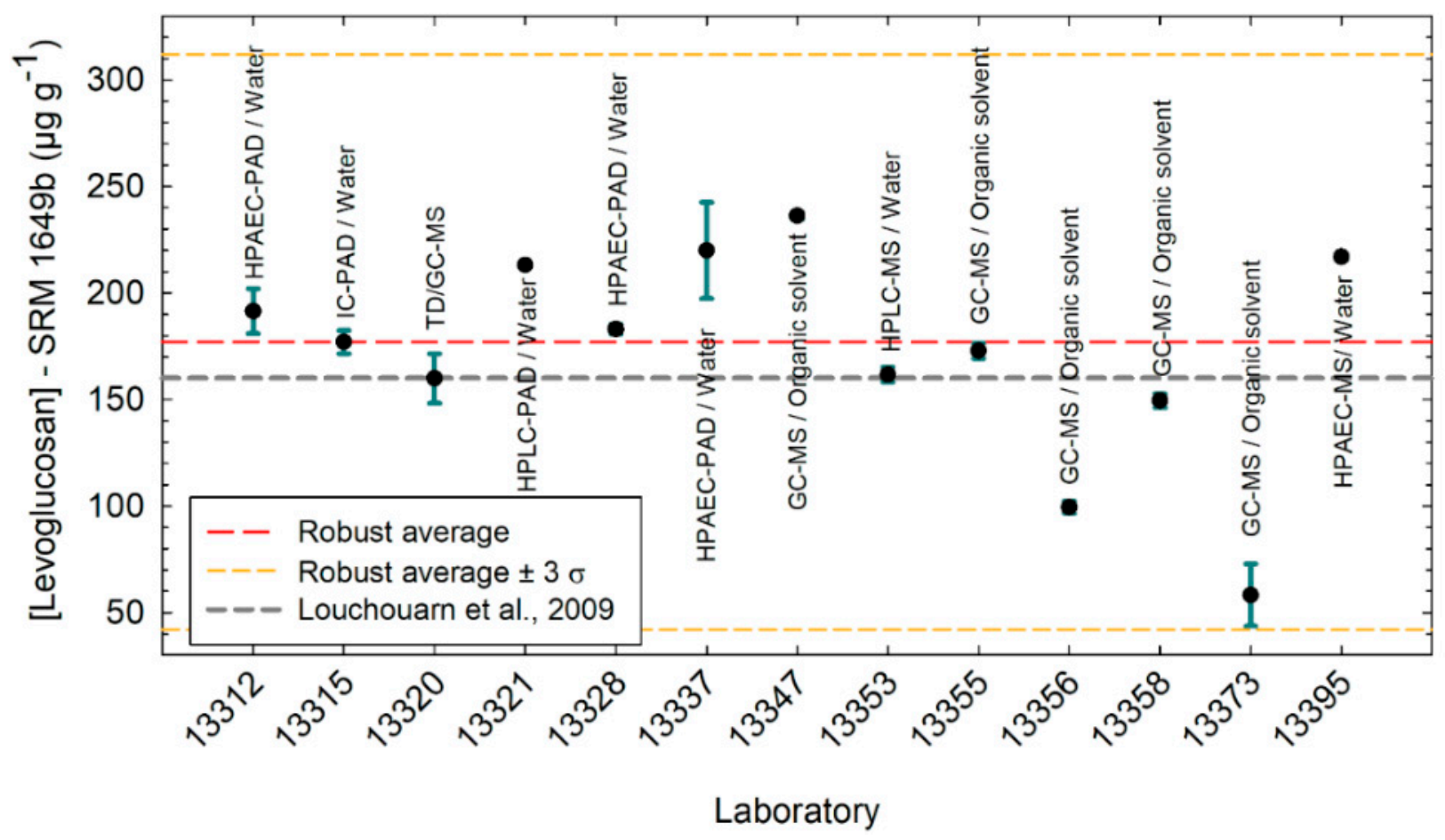

Figure 2. Distribution graph of the concentration values of levoglucosan obtained for the analysis of the NIST SRM 1649b (urban dust) amongst 13 participants (arbitrary identification numbers) and various analytical methods.

\subsection{AE33}

Deployment of AE33 devices within this observational network from 2013 onwards has also been accompanied with ILC exercises at the national scale. The first campaign was performed at the SIRTA facility in the fall 2014, gathering 19 instruments and 10 AASQAs. Instruments were installed and individually verified by the participants-including leak tests, calibration of sample flow rates, and mitigation measures-before being operated in ambient air for a period of 2 weeks (25 September-6 October 2014). Weather conditions were relatively mild during this intercomparison period, with average quarter-hourly temperatures ranging from $5{ }^{\circ} \mathrm{C}$ to $30^{\circ} \mathrm{C}$. A wide range of eBC concentrations, ranging from nearly 0 to about $8 \mu \mathrm{g} / \mathrm{m}^{3}$ (calculated here as the average of the data provided by all AE33) could be sampled. 
Figure 3 presents the Z-scores obtained for each instrument for the following parameters: $\mathrm{eBC}, \mathrm{eBC}_{\mathrm{ff}}$, and $\mathrm{eBC}_{\mathrm{wb}}$ concentrations, as well as the measured Angström exponent $(\alpha)$. Only two instruments (among the first ones to be produced by the manufacturer) presented a Z-score requiring corrective action (i.e., shipment to the manufacturer for maintenance and upgrade), confirming the good general behavior of the vast majority of AE33 devices used within the CARA program. A very good agreement between other instruments could indeed be observed for each investigated parameter. In particular, and despite the light influence of biomass combustion on eBC levels (less than $10 \%$, on average over the campaign), a satisfactory overall agreement was obtained for the $\mathrm{eBC}_{\mathrm{wb}}$ concentrations related to this source.

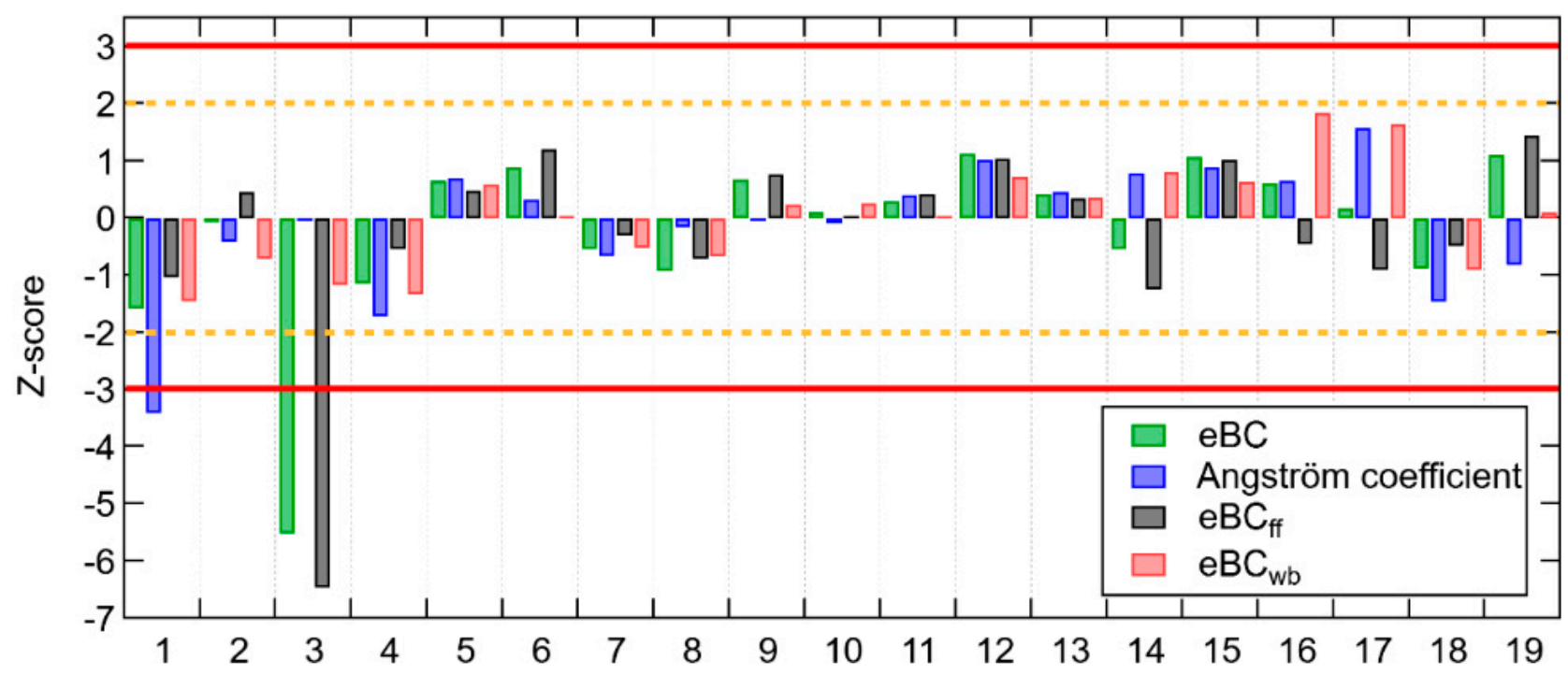

Figure 3. Z-scores obtained for $\mathrm{BC}, \mathrm{eBC}_{\mathrm{ff}}, \mathrm{eBC}_{\mathrm{wb}}$ concentrations and Angström exponent for $19 \mathrm{AE} 33$ instruments (ordered according to increasing serial number).

It may be noted that a similar ILC exercise was performed in the spring of 2019, leading to similar results as those obtained during this first campaign (unpublished results).

\subsection{ACSM}

Expertise developed on ACSM measurements at the SIRTA facility and then within the CARA program has led to the establishment of the ACMCC, which was selected as a unit of the ACTRIS topical center for aerosol in situ measurements. ACMCC notably organizes ILCs within the ACTRIS [34,62], as well as for ACSM operated by AASQAs. Here, we briefly present results obtained during the last ILC campaign performed at the national scale in June 2019. This campaign included eight ACSMs of the CARA program and were performed following three successive steps:

(1) Instruments were installed and operated by AASQAs in ambient air for 3 days.

(2) Response factor and relative ion efficiency calibrations, as well as general tuning operations, were carried out by ACMCC personnel.

(3) Instruments were operated in ambient air for another period of 5 days, to check calibration and tuning accuracies, as well as to compare instrument performances before and after servicing.

Figure 4 reports, for each measured chemical species, the evolution of the standard deviations obtained from the eight instruments as a function of the mean concentration, before and after calibrations. First, we note that these standard deviations exponentially decrease with concentrations, clearly illustrating higher uncertainties at lower loadings, for each chemical species. Nevertheless, these standard deviations reach an asymptotic plateau, relatively, rapidly towards the lowest standard deviation values, pointing to 
reproducibility measurement uncertainties below $20 \%$ for nitrate, sulfate, and ammonium loadings typically higher than $0.5 \mu \mathrm{g} / \mathrm{m}^{3}$, and for OA concentrations typically higher than $1.5 \mu \mathrm{g} / \mathrm{m}^{3}$. Similar decreasing features are also observed for chloride, with, however, much higher dispersion of the data points, due to extremely low concentrations (below $0.1 \mu \mathrm{g} / \mathrm{m}^{3}$ ). Finally, these ACSM measurement standard deviations are only slightly improved after calibrations and tunings, illustrating the overall good performance of the ACSM at their respective measurement stations before the ILC exercise.
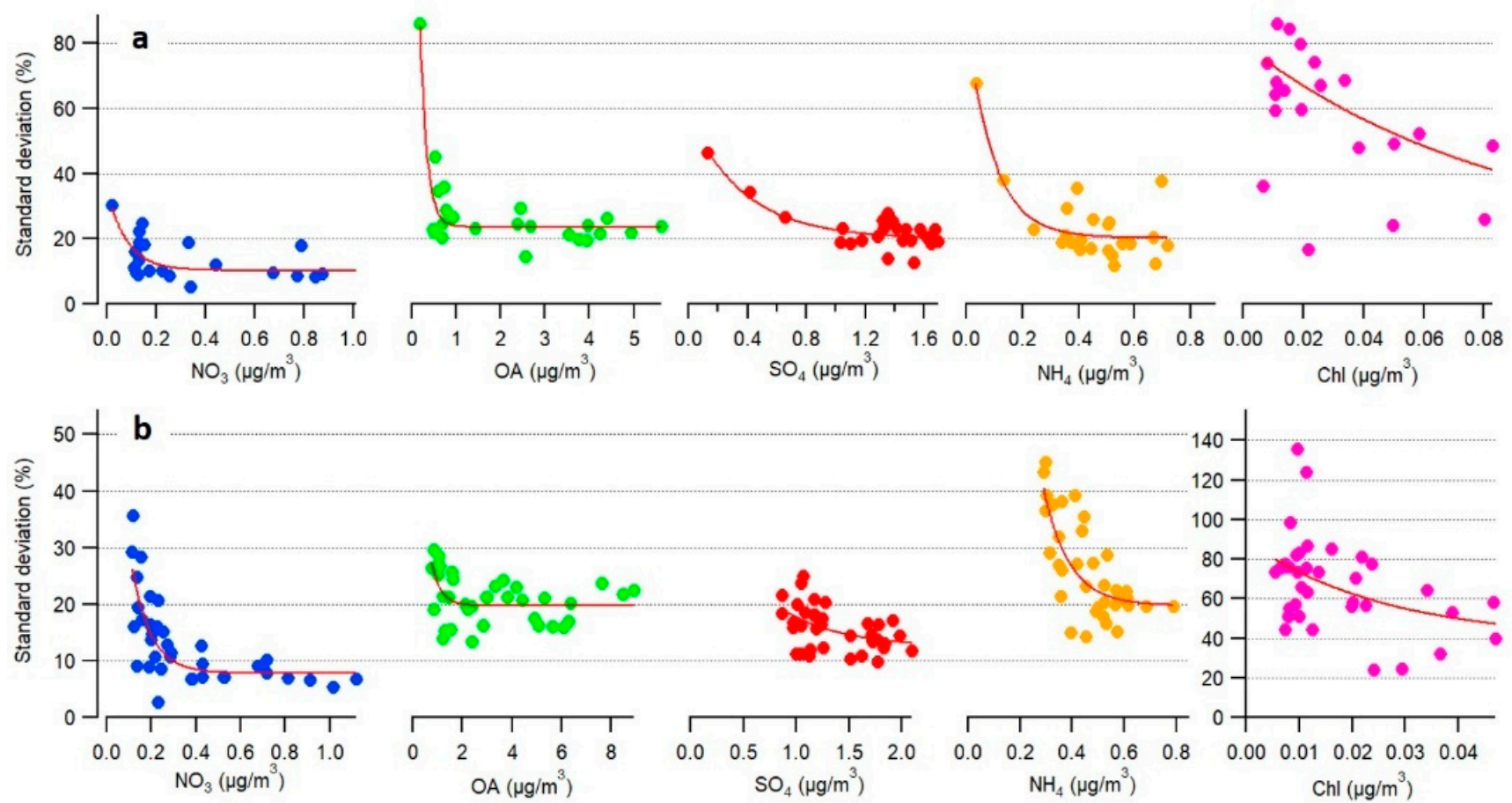

Figure 4. Standard deviations of 8 co-located ACSM measurements before (a) et after (b) response factor (RF) and relative ionization efficiency (RIE) calibrations during the 2019 ILC campaign.

\section{Aerosol Chemical Composition: Overall Picture}

\subsection{Seasonality and Spatial Distribution of the Main $P M_{10}$ Components}

Figure 5 summarizes the longest (semi-)continuous datasets that could be obtained so far from offline chemical analyses of the main $\mathrm{PM}_{10}$ components within the program. Based on monthly-mean concentrations, it exemplifies long-term variations of these components at four French urban background environments, for which every day (Rouen), every second day (Bordeaux), or every third day (Grenoble and Creil) filter samples were analyzed routinely during the last decade.

For simplicity and harmonization purposes, components that are not directly measured by chemical analyses have been roughly estimated here (and in Section 4.3) using the following constant conversion factor assumptions:

- $\quad \mathrm{OM}=1.8 \times$ OC (e.g., [53]);

- $\quad$ Sea salts $=3.27 \times \mathrm{Na}^{+}$, and non-sea salt sulfate $\left(\right.$nss- $\left.-\mathrm{SO}_{4}{ }^{2+}\right)=\mathrm{SO}_{4}{ }^{2+}-0.25 \times \mathrm{Na}^{+}$, based on seawater composition;

- $\quad$ Mineral dust $=8 \times \mathrm{Ca}^{2+}[8,35]$.

In addition, the spatial distribution and the seasonality of some key chemical species are provided for 18 French sites in Appendix B. 


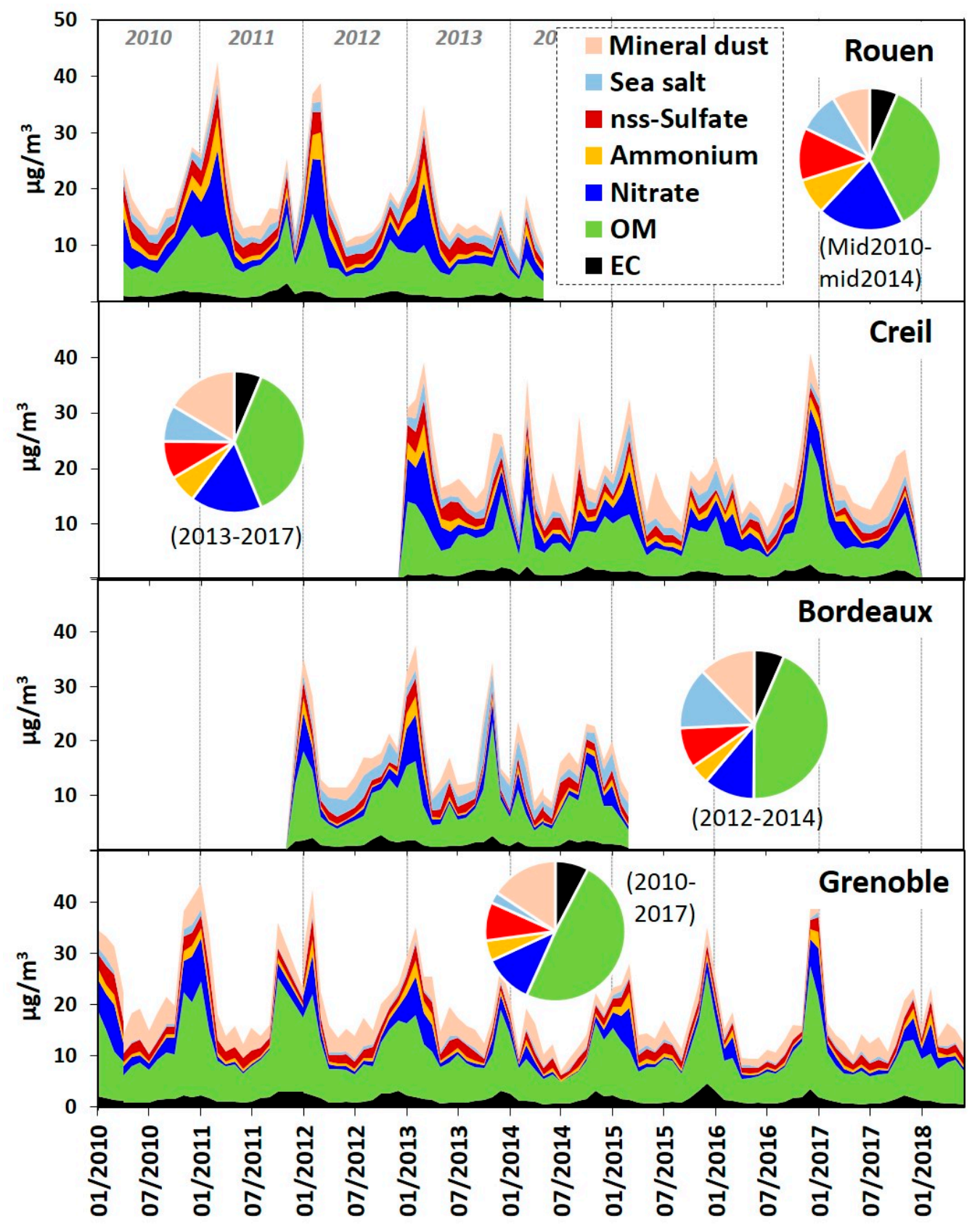

Figure 5. Multi-year variations of main $\mathrm{PM}_{10}$ components (monthly-mean values) as measured at 4 sites of the CARA program over the period 2010-2018.

OM appears as the predominant component at all sites, with typical $\mathrm{PM}_{10}$ relative contributions of $40-45 \%$ on a yearly basis. It is also the main driver of PM temporal variations, displaying a clear seasonality with maxima during the winter season. These observations reflect the diversity and the significance of the various OM origins, including a large zoo of primary (natural and anthropogenic) emission sources, but also multiple secondary formation processes in the atmosphere (again from both biogenic and anthropogenic gaseous precursors) [39]. Winter maxima can be partly explained by generally lower planetary boundary layer height at low ambient air temperatures, concentrating all pollutants in a narrow mixing layer. This feature is also related to additional primary sources compared to the rest of the year, especially residential wood burning for heating purposes (Section 5). A first insight into the strong influence of this specific source is given by the highest wintertime OM relative contribution in Grenoble compared to the three 
other sites presented in Figure 5, as well as the highest wintertime OC and levoglucosan absolute concentrations recorded for the different Alpine sites, compared to other French sites (Appendix B). Moreover, Bordeaux surprisingly reveals biomass burning influences almost as important as those observed for Alpine sites, e.g., with similar levoglucosan loadings, which has been confirmed by comprehensive studies $[42,54,63]$. Other major contributors to OM include vehicular exhaust emissions (Section 6), primary biogenic particles (Section 7), and SOA (Section 12).

Mineral dust happens to be the second largest contributor to $\mathrm{PM}_{10}$ in Creil, Bordeaux, and Grenoble. Similarly to OM, this component is assumed to represent a wide diversity of natural and anthropogenic emission sources, including construction works, non-exhaust vehicular emissions (Section 6), transport of soil material from arable lands to urban environments, as well as transport of Saharan dust over the metropolitan territory, but also to the French West Indies (Section 10) [9,64-66]. Amongst other possible emission sources, one should also mention rare volcanic ash emission events, such as the one that led to the interruption of airplane traffic, but also influenced air quality in northeastern France in the spring 2010 [27]. Overall, maximum mineral dust contributions to $\mathrm{PM}_{10}$ are assessed here from spring to autumn, notably due to lower concentrations of some other $\mathrm{PM}_{10}$ components (starting with $\mathrm{OM}$ ), but also due to more intense emissions and drier ambient air conditions during this period of the year.

Nitrate can be considered as the main second driver of $\mathrm{PM}_{10}$ seasonal cycles, with highest concentrations and relative contributions in late-winter/early-spring, especially in the northern part of France (Figure 5 and Appendix B). This is related to the formation mechanisms and the semi-volatile nature of ammonium nitrate. Indeed, this secondary species results from the oxidation of nitrogen oxides $\left(\mathrm{NO}_{\mathrm{x}}\right)$ and byproduct combination and/or condensation with ammonia $\left(\mathrm{NH}_{3}\right)$ in the particulate phase [67]. Its concentration in ambient air is therefore notably dependent on the availability of its gaseous precursors and on the strength of (photo-)chemical atmospheric processes. In late-winter/early-spring, intense agricultural activities, including the spreading of fertilizers, under anticyclonic conditions, induce a substantial increase of nitrate and ammonium concentrations within the $\mathrm{PM}_{2.5}$ fraction (Section 10). Such a phenomenon furthermore relies on the meteorological conditions as ammonium nitrate is submitted to partitioning between the gaseous and the particulate phases as a function of ambient temperature, hygroscopicity, and internal mixing with other compounds [67], which also partly explains the spatial and seasonal nitrate distributions illustrated in this paper.

As nitrate, sulfate originates almost exclusively from secondary formation mechanisms involving gaseous precursors $\left(\mathrm{SO}_{2}\right)$ emitted by natural sources and anthropogenic activities. Note that primary sulfate contained in sea salts has been removed to total sulfate concentrations presented in Figure 5, therefore illustrating the behavior of non-sea salt sulfate (nss-sulfate) at the four sites exemplified here. Contrary to nitrate, ammonium sulfate is a low volatile species, so that it can stay in the particulate phase at elevated ambient air temperature, i.e., in summer, when enhanced photochemical processes favor its formation with subsequent increase of sulfate loadings in PM (Section 11).

It should be mentioned that sulfate (as well as nitrate and SOA) can also be present in the coarse aerosol mode (i.e., $2.5-10 \mu \mathrm{m}$ ), notably resulting from the adsorption of gaseous species via acid-base surface reaction on crustal particles or sea salts (whose spatial distribution is discussed further in Section 8).

Finally, if discarding concentration peaks observed in December 2016, Figure 5 seems to picture the decreasing long-term trends that have been described elsewhere for regulated $\mathrm{PM}_{10}$ and/or $\mathrm{PM}_{2.5}$ total mass concentrations over France and Europe $[7,68]$. In agreement with results obtained from a preliminary analysis performed using the SIRTA online measurement datasets for the 2011-2018 period [46], these PM decreasing features could be mainly driven by the reduction of the ambient concentrations of both nitrate and OM (especially its hydrocarbon-like and its highly oxidized fractions). However, sound statistical analyses require longer datasets (e.g., >10 years) than the ones discussed here 
to accurately evaluate long-term trends for each of the main chemically-speciated $\mathrm{PM}_{10}$ components.

\subsection{Diel Variations of the Main Components of the Fine Aerosol Mode}

As mentioned above, high-time resolution AE33 and ACSM measurements benefits the CARA program to continuously document the chemical composition of the fine aerosol mode $\left(\mathrm{PM}_{1} / \mathrm{PM}_{2.5}\right)$. They also allow refining our understanding of the main anthropogenic PM sources, as well as of the influences of atmospheric dynamics and meteorological conditions on urban air quality.

Figure 6 summarizes the yearly-average diel variations of OA, nitrate, sulfate, ammonium, and eBC measured by ACSM and AE33 at seven sites of the CARA program in the years 2017-2018. As for the $\mathrm{PM}_{10}$ fraction, $\mathrm{OA}$ is the main contributor to the fine aerosol fraction. ACSM data exhibit evening peaks at all sites, more prominent in winter due to both residential heating emissions of wood burning and a lower boundary layer height. This also strongly reflects in the eBC diel profiles (Figure 7). A smaller peak of OA in the morning at some sites, concomitant to an $\mathrm{eBC}$ peak, point out primary emissions due to traffic exhaust. Being representative of background air quality of the Paris region, SIRTA is less influenced by these local emissions and displays smoother variations.

For inorganics, very similar profiles are obtained for both ammonium and nitrate, illustrating the overall predominance of ammonium nitrate over ammonium sulfate in French urban atmospheres. Due to its semi-volatile nature, ammonium nitrate is very much dependent on the meteorological conditions, with a peak in the late-night/early-morning before the daytime temperature and boundary layer heights increase, leading to reduced particulate phase concentrations. Interestingly, the profiles exhibit a decreasing gradient from north to south and east to west, with Lille showing the highest concentrations and Marseille the lowest ones (Figure 6).
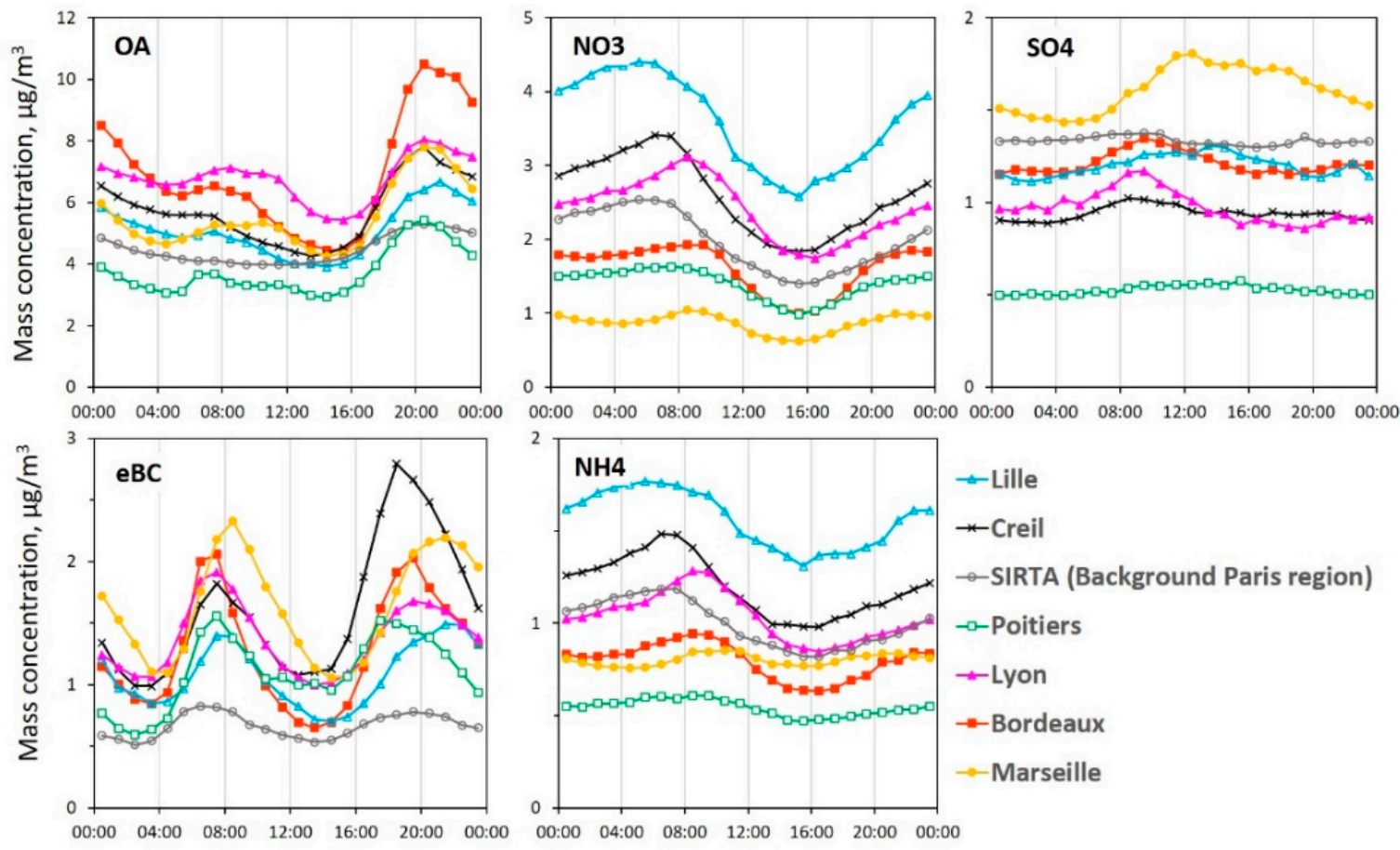

Figure 6. Mean diel variation of the main components of the fine aerosol mode as measured at seven sites of the CARA program in the years 2017-2018. 


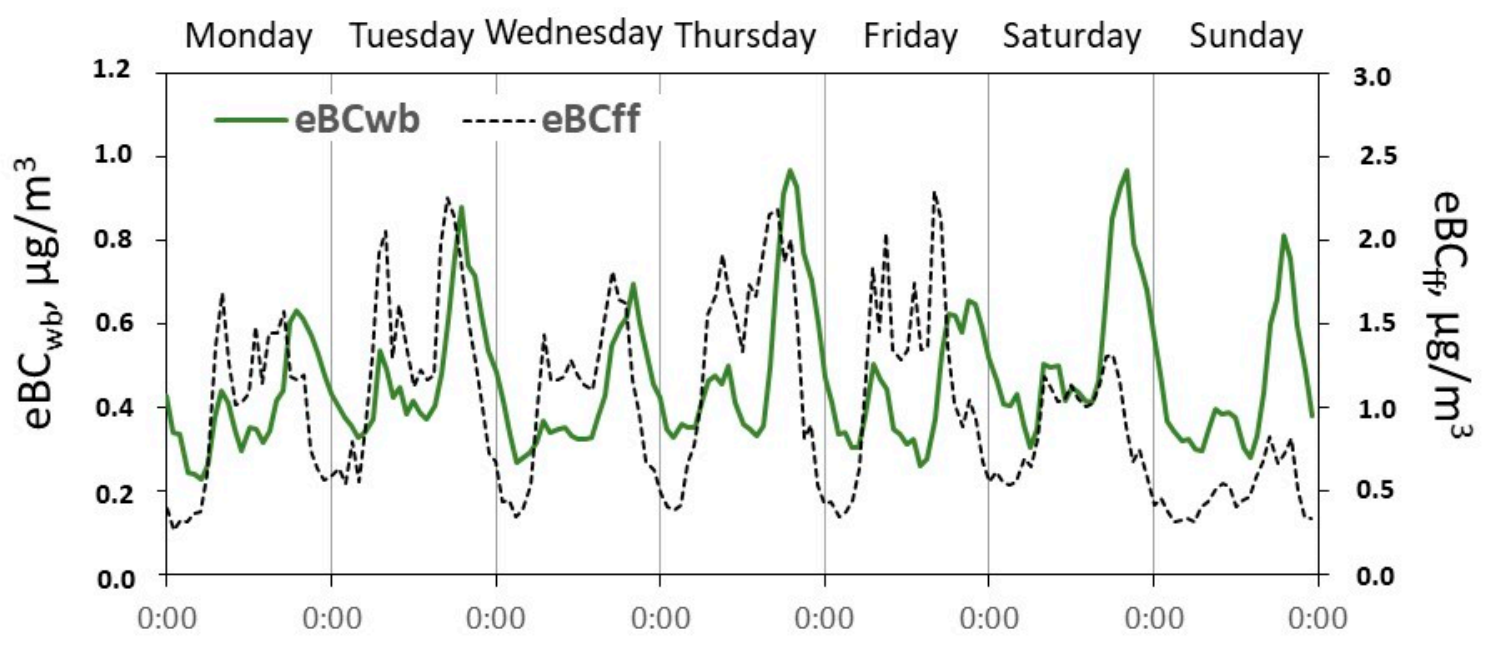

Figure 7. Mean weekly diel variations of $\mathrm{eBC}_{\mathrm{wb}}$ and $\mathrm{eBC}_{\mathrm{ff}}$ concentrations at the Poitiers urban background station during the winter season (2017-2018).

As mentioned above, sulfate concentrations in the atmosphere mostly originate from the conversion of $\mathrm{SO}_{2}$, whose sources can be natural (marine emissions) or anthropogenic (industrial, shipping). Far from emission sources, the diel profile reflects rather long-range transport of non-volatile ammonium sulfate (Paris region, Lille, Creil, Poitiers), whereas more local/regional sources are expected at the sites in Lyon, Bordeaux, and Marseille, where enhanced photochemistry in summer also likely plays a role.

\subsection{Pollution Episodes Commonly Observed within the CARA Program}

As discussed in Section 3.1, highest monthly-mean PM concentrations are quasisystematically observed during a period covering winter and early spring. Logically, this period of the year also corresponds to the predominant occurrences of persistent and large-scale pollution episodes (i.e., with $\mathrm{PM}_{10}$ daily concentrations above $50 \mu \mathrm{g} / \mathrm{m}^{3}$ for at least three consecutive days, affecting several administrative regions at the same time). The chemistry of such PM pollution episodes is highly dependent on meteorological conditions and on the type of emission sources, which prevail while they occur. Figure 8 presents two contrasted examples of such episodes, clearly illustrating their diversity.
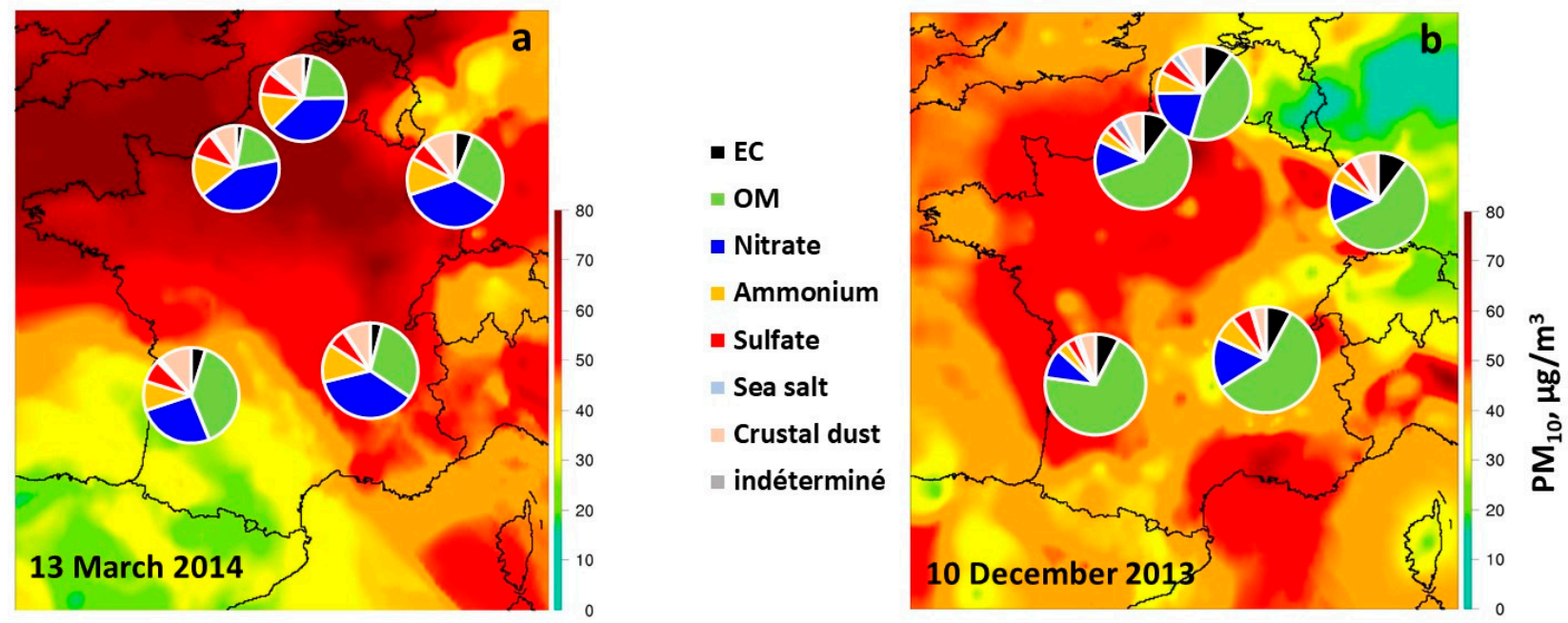

Figure 8. Examples of daily $\mathrm{PM}_{10}$ chemical composition observed for five urban stations (Lens, Rouen, Strasbourg, Lyon, and Bordeaux) during two different types of pollution episodes, along with $\mathrm{PM}_{10}$ concentration mapped using the Prev'Air modeling system (http:/ / www2.prevair.org) analyzed with in situ PM 10 measurements. (a) 13 March 2014, (b) 10 December 2013 
Figure 8a pictures a typical springtime PM pollution episode dominated by secondary aerosols and more specifically ammonium nitrate. The time-evolution of this episode, which occurred in March 2014, is extensively detailed elsewhere for the Paris region, using a whole set of in situ and remote sensing measurements at the SIRTA facility [69]. The chemical composition of a similar episode, occurring the following year (March 2015), could be further documented using multi-sites ACSM and AE33 measurements [29]. Briefly, this type of episode starts with extremely stable weather conditions associated with very low wind speed, favoring the increase of $\mathrm{PM}_{10}$ in northern France and in the Rhône-Alpes area. Then, anticyclonic conditions associated with (north-)east wind sectors transports polluted continental air masses from neighboring countries, contributing to a sharp deterioration of the situation in France. High loadings of (ammonium) nitrate can be observed at all sites in the northern and eastern parts of the metropolitan territory, which can be related to enhanced ammonia emissions from agricultural activities (manure spreading) in this period of the year. This observation generally applies to all types of stations (traffic, urban and rural background), leading to much more homogeneous pollution distribution than during early-wintertime episodes (Figure $8 \mathrm{~b}$ ). This demonstrates the regional character of this type of PM pollution episode, with large-scale production of secondary aerosols being its main determining factor. Since ammonium nitrate formation needs $\mathrm{NH}_{3}$ emissions, but also $\mathrm{NO}_{\mathrm{x}}$ emissions, the latter ones primarily originating from road transport and other combustion activities (e.g., industries), agricultural activities cannot be considered as the only ones responsible for the occurrence of this type of episode. Such a late-winter/early-spring episode commonly ends with the breakdown of anticyclonic conditions, bringing oceanic air masses from the western wind sector over the north of France whereas the pollution plumes evacuates passing through south-west French regions. This type of persistent and large-scale episode occurred almost every year around the 2010s [70], which, in fact, initially motivated the setting-up of the CARA program to better understand the origins of semi-volatile particles that could be recorded when equipping the conventional monitoring tapered element oscillating microbalance (TEOM) instruments with filter dynamics measurement system (FDMS) devices in AASQAs. Interestingly, it was barely observed during the 2016-2020 period, or at a much lower amplitude, possibly reflecting the favorable impacts of nitrogen species emission reductions at the European scale [68,71]. Nevertheless, intense but short-term (1 or 2 day-long) ammonium nitrate-dominated episodes are still recorded in the late-winter/early-spring period (Figure 9) under atmospheric chemistry and dynamic processes that need to be further investigated, but seem to be different from the previous ones.

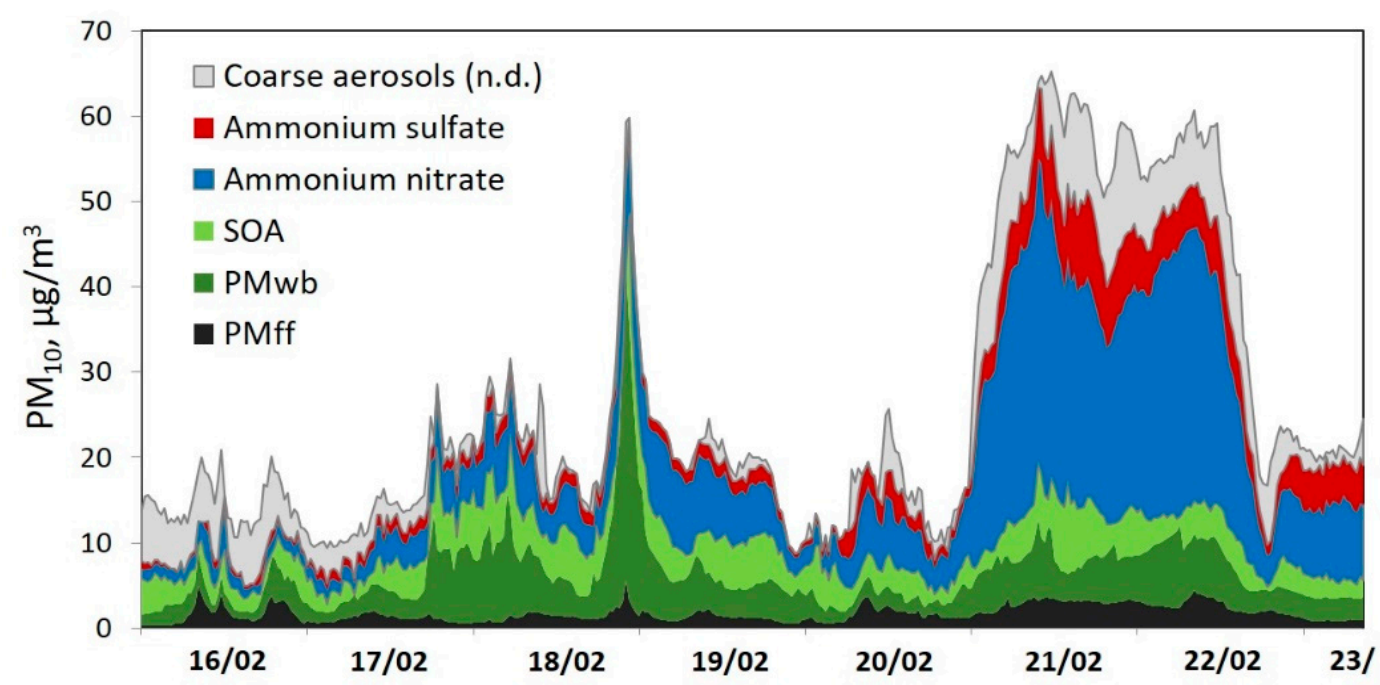

Figure 9. PM $\mathrm{PM}_{10}$ chemical mass closure estimated from ACSM and AE33 measurements at SIRTA in February 2018. 
Figure 8b exemplifies a fully different type of PM pollution episodes, which can develop in wintertime under anticyclonic regime associated with stable and cold weather conditions. Such meteorological conditions favor the accumulation of pollutants at a local scale, trapping them in very thin inversion layers. This results in pollution maps presenting a heterogeneous spatial distribution of PM concentration levels, with highest loadings at the vicinity of prevalent emission zones, i.e., urban areas. Since happening during cold periods, such pollution episodes are concomitant with a greater use of domestic heating, especially residential wood burning. During these events, the PM chemical composition is then dominated by carbonaceous matter, with OM-to- $\mathrm{PM}_{10}$ contributions as high as $70-80 \%$ in some cases (e.g., Bordeaux in Figure 8b). This impressive burden of (primary) carbonaceous aerosols is further assessed as mainly being influenced by domestic human activities. Figure 10 illustrates monitoring data that could be obtained in near-real time by AASQAs using $\mathrm{PM}_{10}$ and multi-wavelength absorption measurements at different urban background stations during such an early-winter pollution episode, which occurred in December 2016. Due to the temporality of residential heating emissions, highest $\mathrm{PM}_{\mathrm{wb}}$ relative contributions, as well as highest $\mathrm{PM}_{10}$ loadings, are generally recorded at nighttime.

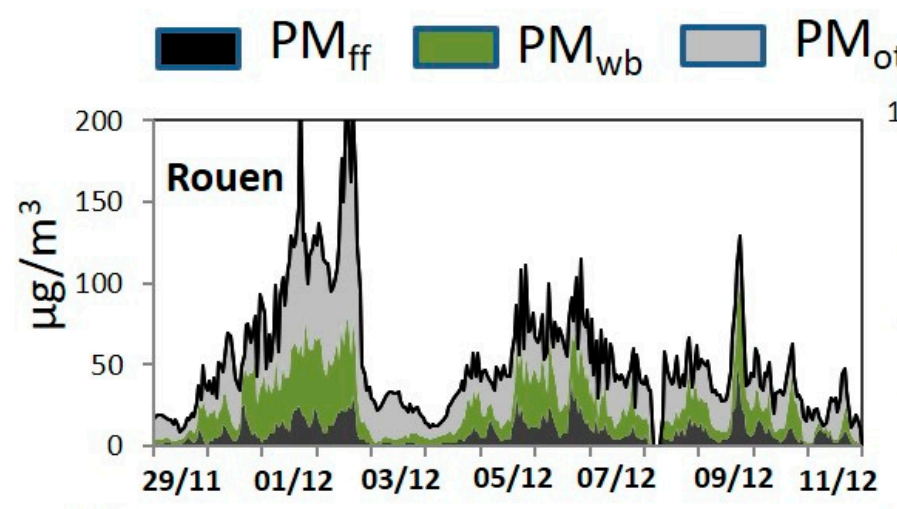

$$
P M_{\text {other }}\left(P M_{10}-\left(P M_{w b}+P M_{f f}\right)\right)
$$
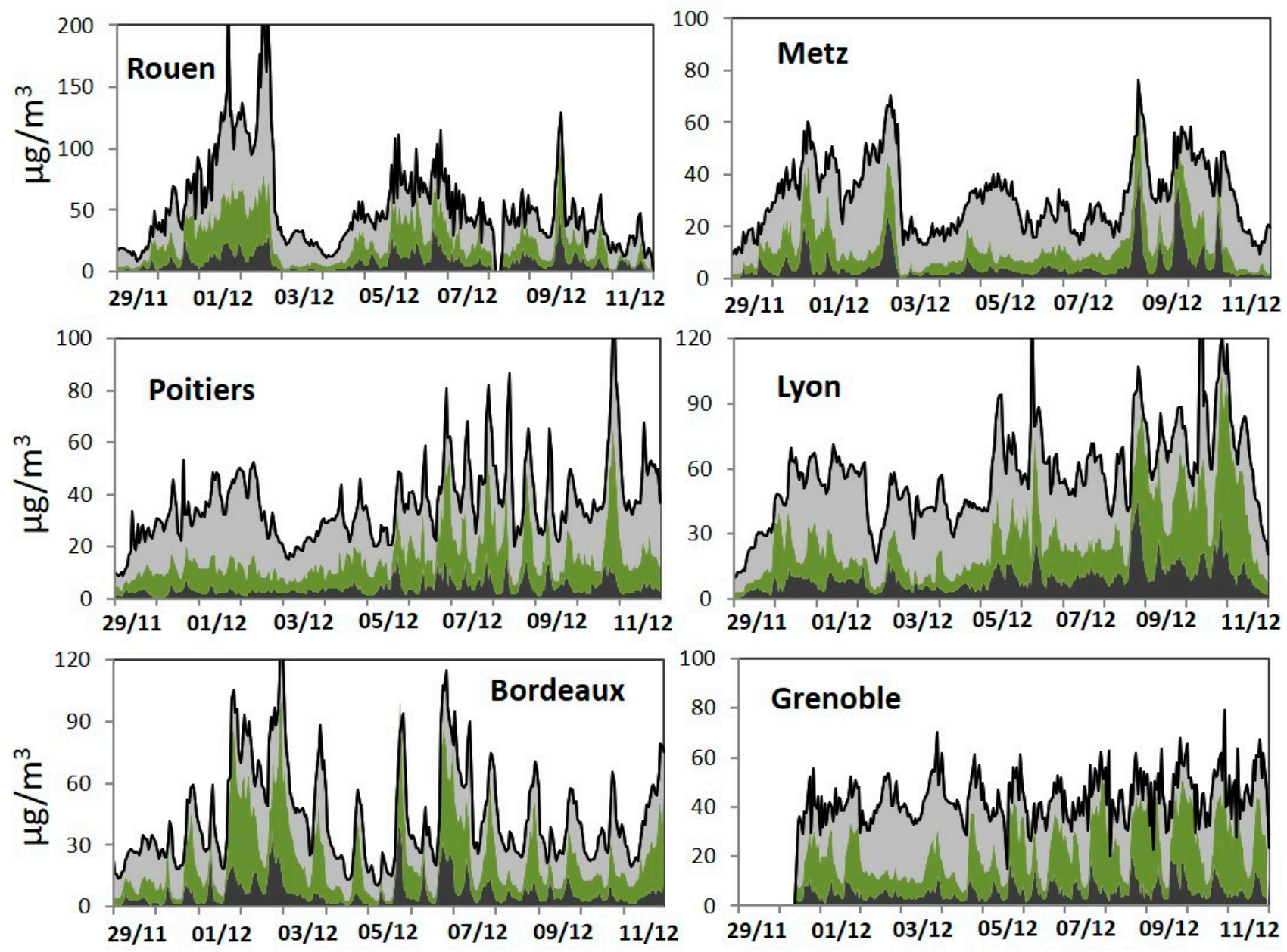

Figure 10. High-time resolution of $\mathrm{PM}_{10}, \mathrm{PM}_{\mathrm{ff}}$, and $\mathrm{PM}_{\mathrm{wb}}$ variations at six sites of the CARA program during the December 2016 pollution episode.

Clearly, local-scale emission abatement strategies might help reduce the impact of such wintertime episodes on urban air quality. Associated action plans that have been developed in recent years all over France, e.g., incentive measures to replace low-efficient 
fireplaces (e.g., using wood stoves) with more efficient (pellet-)burners, should hopefully allow to substantially downscale the magnitude of this type of PM pollution episode in the near-future. Further insights into the overall influence of wood burning emissions on air quality in French urban environments, and the way to evaluate it, is proposed in the following section.

\section{Residential Wood Burning}

Wood burning has been described as a major source of wintertime PM pollution in some of the largest French cities for more than ten years [50,51,72,73]. Yet, it is still a subject of great scientific and political concern, notably due to possible conflicting interest in policy strategies promoting the use of renewable energies.

The high contribution of this primary source to ambient PM loadings is mainly linked with poorly efficient combustion processes, leading to the emission of high amounts of organic species (including PAHs, semi-volatile or intermediate-volatile organic compounds, and highly oxidized organic aerosols). Figure 11 summarizes some follow-up results obtained from the comprehensive work presented in [42], which gathers and synthetizes some of the main outcomes of the so-called SOURCES project $([70,74])$ to analyze preexisting datasets relevant for urban air quality $\mathrm{PM}_{10}$ source apportionment using PMF in a harmonized way. This figure ranks, in order of importance, the contribution of each identified sources to measured OM concentrations at a yearly-average basis. Although this figure does not focus on the winter season only, biomass burning still appears clearly as the first source of organic aerosols influencing overall urban air quality in France, with yearly-average concentrations of roughly $2.5 \pm 1.2 \mu \mathrm{g} / \mathrm{m}^{3}$ (representing about $30 \pm 10 \%$ of total OM loadings). It should be noticed here that energy production is dominated in France by nuclear power plants and liquid fuel, and that coal represents lowest consumption that biomass. The overwhelming influence of residential wood-burning combustion for heating purposes on this biomass burning fraction - compared to other types of biomass burningis notably reflected in $\mathrm{eBC}_{\mathrm{wb}}$ diel variations obtained from $\mathrm{AE} 33$ measurements. Indeed, as exemplified for Poitiers in Figure 7, these patterns display well-marked diel cycles with $\mathrm{eBC}_{\mathrm{wb}}$ concentration maxima at late evening, just following $\mathrm{eBC}_{\mathrm{ff}}$ (traffic emissions) peaks, i.e., when individuals are coming back home. A weekend effect might even be observed at stations located in residential suburban areas, with highest mean concentration peaks observed for Sunday night in winter [28,46]. Nevertheless, some events of open green waste burning may also temporarily influence urban air quality, especially in the fall [75].

As mentioned above, levoglucosan is commonly used as a specific tracer of biomass burning aerosols. This organic compound appears to represent a fairly stable fraction (i.e., $8 \pm 2 \%$ ) of the $\mathrm{PM}_{10}$ biomass burning factor obtained from harmonized PMF analyses described in [42]. These results can be used to check the consistency of $\mathrm{PM}_{\mathrm{wb}}$ estimates obtained from AE33 measurements. This is exemplified here in Figure 12, comparing results obtained from both methodologies for the Grenoble urban background site (Les Frênes) in the years 2015-2018, as well as for various sites of the CARA program during the December 2016 pollution episode presented above. In both of these case studies, a satisfactory correlation is obtained between $\mathrm{PM}_{\mathrm{wb}}$ and levoglucosan concentrations, with slope values of approximately 10 . Note that offset values of the order of $1 \mu \mathrm{g} / \mathrm{m}^{3}$ might however tend to overestimate biomass burning concentrations when emissions are supposed to be limited (typically at summertime). 

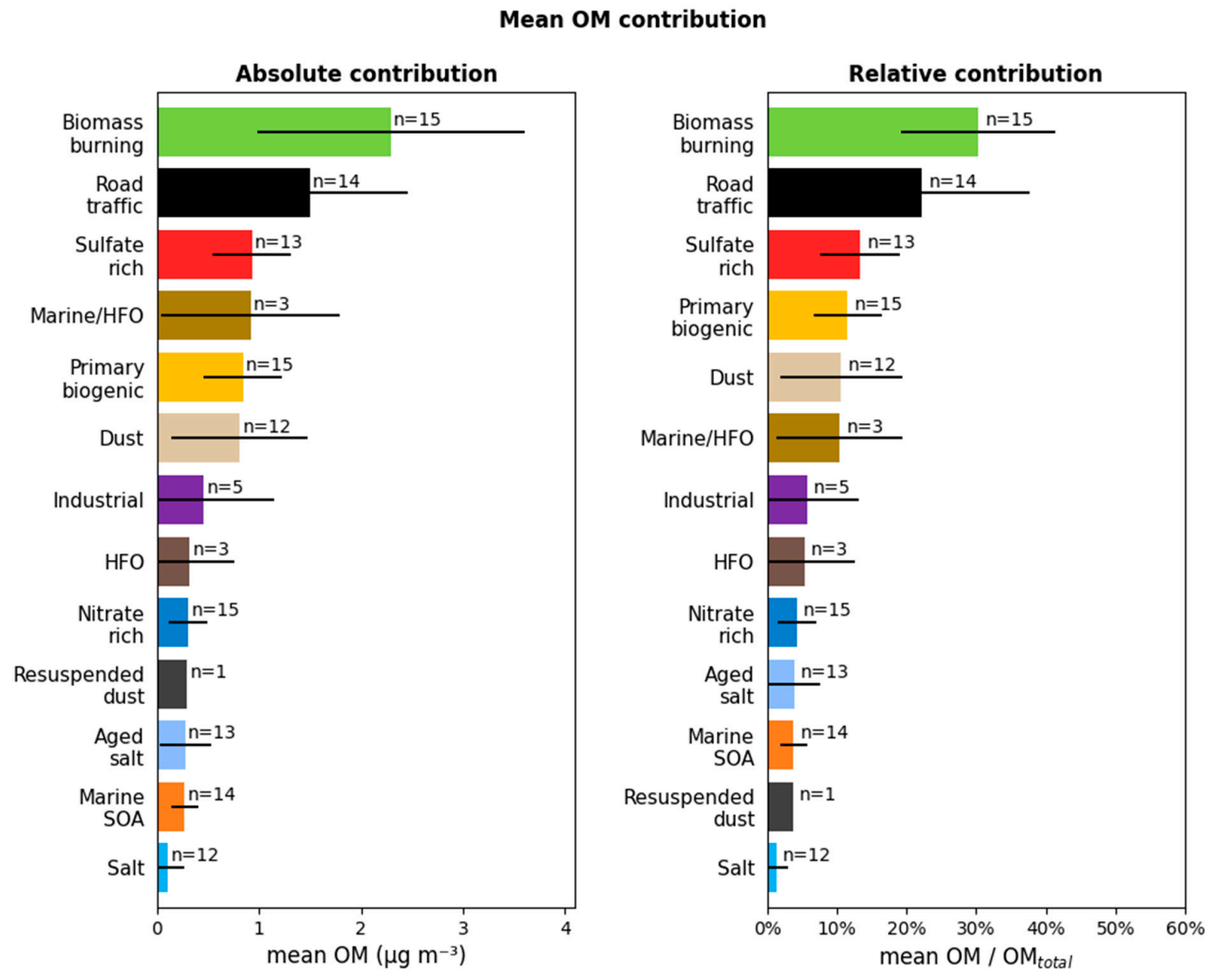

Figure 11. Average and standard deviation of various source contributions to total OM in French urban environments $(n=$ number of sites where the given source profile is defined in the PMF analysis). Left: average concentrations (in $\mu \mathrm{g} / \mathrm{m} 3$ ), Right: average relative contribution (\%). Adapted from work described by Weber et al. [42].
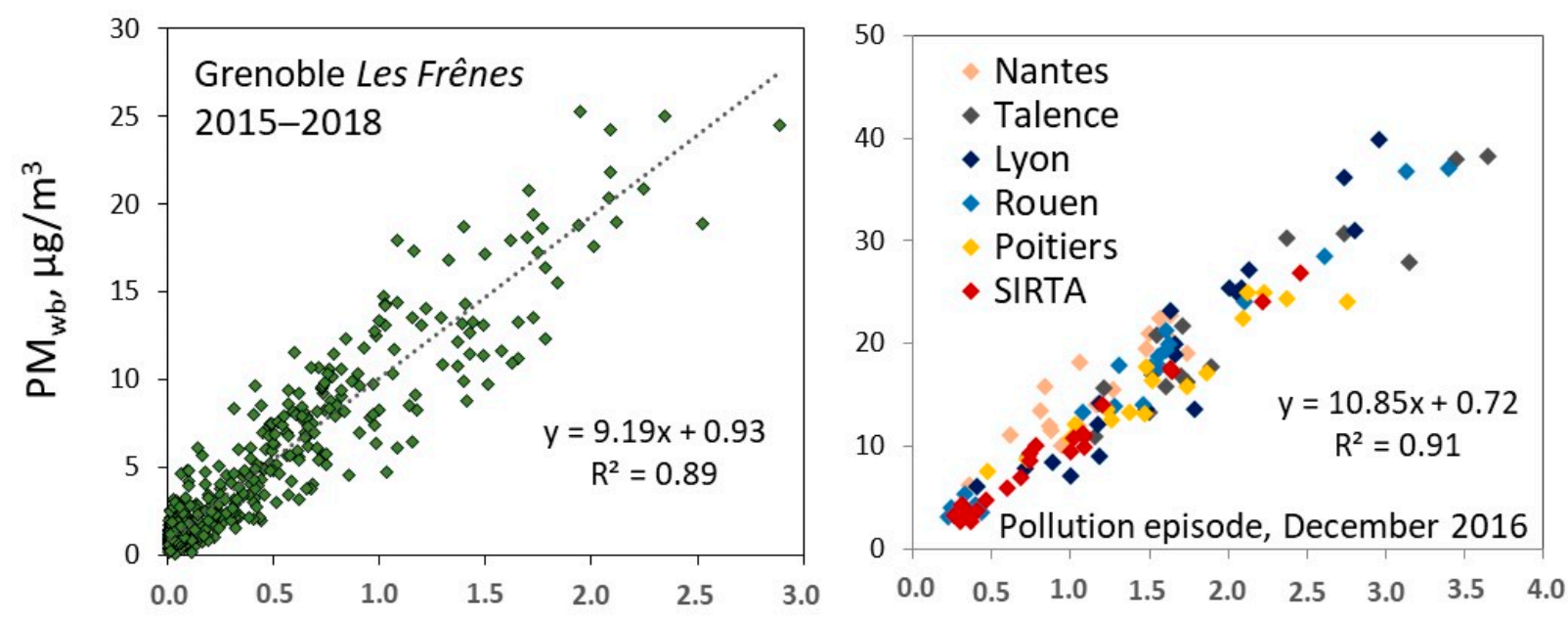

\section{Levoglucosan, $\mu \mathrm{g} / \mathrm{m}^{3}$}

Figure 12. Comparison between $\mathrm{PM}_{\mathrm{wb}}$ (estimated from AE33 measurements as described in Section 2.3) and offline filterbased levoglucosan measurements in Grenoble over the period 2015-2018 (every third day) and at different sites of the CARA program during the December 2016 pollution episode (daily data). 
Despite rather homogeneous contributions of levoglucosan (and OC) within the biomass burning factor from one urban site to another, other species (such as EC, potassium, chloride, and nitrate) display higher variabilities [42], which can be partially explained by fluctuations in the type of wood which is used and/or in burning conditions. Furthermore, biomass burning emissions in ambient air may favor (i) nighttime mechanisms leading to the condensation of ammonium nitrate in the particulate phase [76]; (ii) the build-up of SOA onto wet aerosols [77]; and (iii) the formation of organo-nitrate (or nitrated organic compounds) and/or organo-sulfate [41,78], probably increasing the impacts of wood burning emissions into wintertime urban air quality up to levels of complexity, and of magnitudes that are still to be better understood and quantified. As some of the secondary compounds formed through these processes are absorbing light at near-ultraviolet wavelengths [77,79], it may be assumed that they are partially detected and somehow accounted along with primary biomass burning aerosols when using the Aethalometer model [51,79]. For ACSM measurements, the diversity of emitted species and secondary processes potentially involving them, makes it difficult to acknowledge that they can always be fully captured in a single (BBOA) factor obtained from classical PMF analysis applied to organic mass spectra [48,80-82]. In this context, results potentially obtained for this BBOA fraction from classical and automated ACSM organic mass spectra PMF data treatment procedures within an operational network, such as the CARA program, may happen to be misleading for the public and decision makers. Further investigations and methodological developments, e.g., using constraints from independent and complementary methodologies, are still to be tested before implementation in a routine way (see also Section 12).

\section{Road Transport (Primary Emissions)}

On average, annually and overall, road transport is the second contributor to OM loadings affecting air quality in French urban environments (Figure 11). Related organic aerosols are assessed to originate from tailpipe emissions (along with roughly equivalent EC loadings), but also from non-exhaust emissions, including resuspension of various types of particles that may deposit on the road $[66,83]$. Substantial amounts of metallic species are also expected to be related to various traffic-related abrasion phenomena (from road surfaces, tires, brake pads, etc.). In practice, the discrimination between vehicular exhaust and non-exhaust particles appears to be hardly possible when applying a classical PMF approach on chemical speciation data obtained at urban background conditions. Similarly, gasoline and diesel tailpipe emissions are barely separated by receptor models at background sites. The mixing of these different emission types in a single PMF factor leads to rather heterogeneous primary traffic chemical profiles obtained from a given site to another [42]. However, source apportionment studies conducted at roadside monitoring stations might allow to delineate them between two (or more) specific fingerprints, as exemplified hereafter with results recently obtained for a traffic-oriented station (so-called Renéville) of Fort-de-France, as part of a recent study conducted in Martinique Island (see Section 9 and [84]).

Briefly, $89 \mathrm{PM}_{10}$ daily filter samples collected by Madininair AASQA at Renéville over 2018 were analyzed offline by the LCSQA. A relatively small set of chemical variables (31) were selected and used within the input data matrix to fulfill equilibrium requirements between the number of samples and the number of chemical species [44]. Six factors could be obtained from this PMF analysis. Figure 13 presents the relative contributions of each of these six factors to $\mathrm{PM}_{10}$ concentrations as well as to each of the individual chemical species considered here. Besides Saharan dust, sea salts, biomass burning, and industrial activities, two factors are assumed to be related to road transport. The first one-Road transport 1 - exhibits a relatively low EC/OC ratio (0.5) and includes almost all antimony and tin measured at this station, whereas the second one-Road transport 2-displays a much higher EC/OC ratio (about 2.6) and a high chromium contribution. These profiles suggest a possible differentiation of (i) light-duty vehicles equipped with gasoline engine and metalloid-lined brakes, and (ii) other types of (heavy-duty) vehicles equipped with 
diesel engine and/or chrome plated cast iron brakes [85]. Alternatively, it might also be hypothesized that the first factor mainly corresponds to non-exhaust vehicular emissions while the second one is primarily composed of exhaust emissions (with chromium, but also other elements, such as molybdenum or copper, possibly originating from catalyst converters). Further works, including detailed investigations of the elemental and isotopic composition of non-exhaust road transport emissions [86], might greatly help to better evaluate the impact of these sources on urban air quality.

Overall, primary particles related to road transport emissions are assessed to represent about $15 \%$ of annual mean $\mathrm{PM}_{10}$ concentrations recorded in French cities [42]. It is reminded here that gaseous tailpipe emissions contribute also substantially to ammonium nitrate (Section 10) and SOA (Section 12) formation in urban environments. Furthermore, road transport is a significant source of ultrafine particles (UFP) whose monitoring in French urban environment will be developed at the operational level in coming years [87].

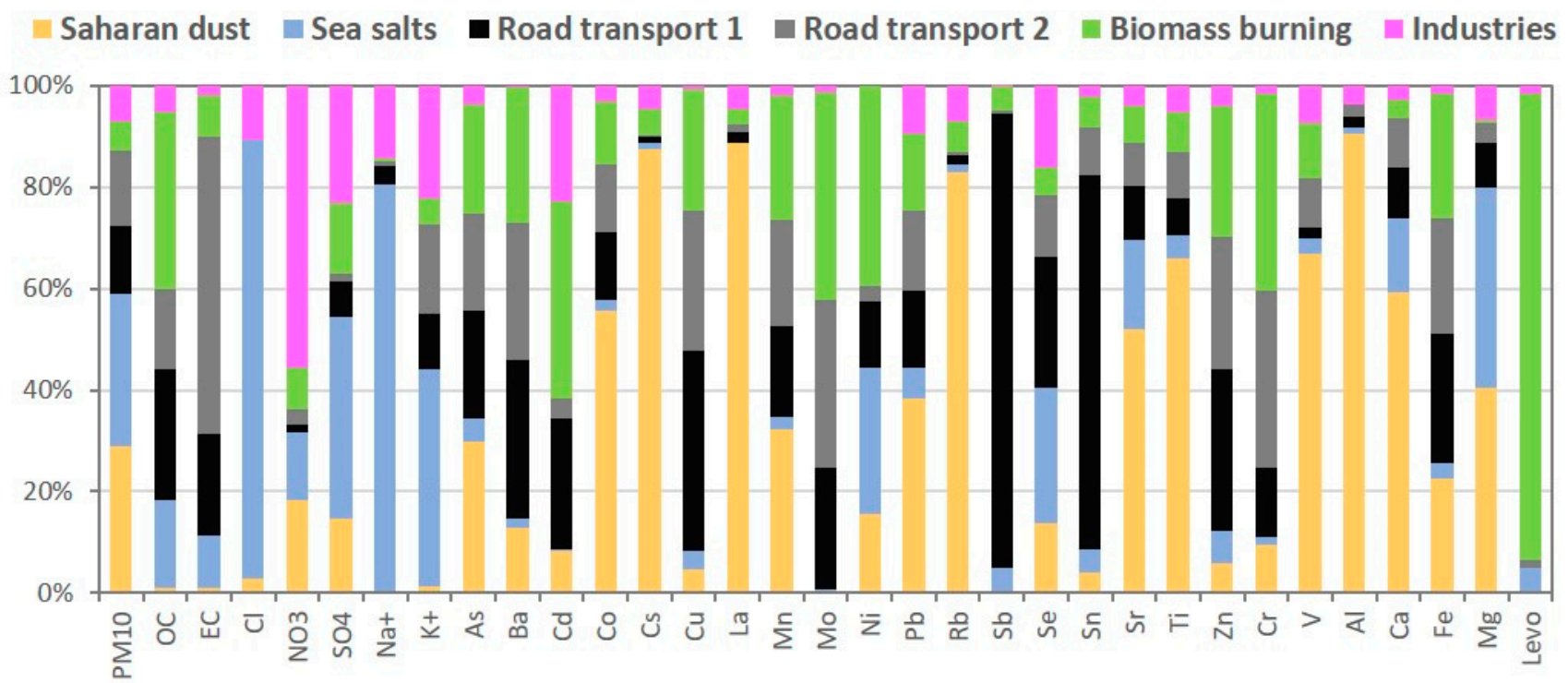

Figure 13. Relative contribution of six PMF factors to $\mathrm{PM}_{10}$ and individual chemical species measured at a roadside site of Fort-de-France (Martinique Island) in 2018.

\section{Primary Biogenic Organic Aerosols (PBOA)}

Besides anthropogenic activities, vegetation may also be a substantial contributor to primary OM emissions $[88,89]$. The large number of CARA stations, combined with many other series of samples from specific complementary programs, has made it possible to produce a national synthesis on the importance of such emissions in the $\mathrm{PM}_{10}$ fraction. Based on the use of polyols as PBOA markers [22,90], it has been shown that primary OM emissions associated with fungal species might represent up to about $40 \%$ of the total summertime-averaged $\mathrm{OM}$ concentration in $\mathrm{PM}_{10}$ at some urban background stations (Figure 14). With much lower influence at some other stations, an overall summertime contribution of about $25 \%$ can be considered on average at the national level during this season. On a yearly basis, OM comprised in fungal spores are assessed to represent an annual mean concentration of about $1 \mu \mathrm{g} / \mathrm{m}^{3}$ in French urban background environments.

Size-segregated offline chemical speciation measurements also indicate that these particles are essentially present in the coarse fraction of $\mathrm{PM}_{10}$, with relatively similar temporality and high spatial homogeneity of concentrations at sub-regional scale (at least $100 \mathrm{~km}$ ). Furthermore, these chemical species have been demonstrated to be strongly associated with the abundance of specific fungal genera, which are distinct in different climates and are carried by vegetation rather than from the soil. This is particularly true 
in rural areas of field crops, where agricultural activities are highly emitting (especially during harvest) $[26,91]$.

It should also be underlined that fungal spores are not the only type of PBOA. In particular, it is likely that another substantial part of the bioaerosol loadings is made up of plant debris that can be measured directly via the free cellulose in $\mathrm{PM}_{10}$. Some of the first published annual cycle measurements show that concentrations of the order of several hundred $\mathrm{ng} / \mathrm{m}^{3}$ may be present, again in the coarse fraction of $\mathrm{PM}_{10}$, throughout the year [20]. The spatial variability of these concentrations at the urban scale is quite high, indicating nearby sources for this fraction.

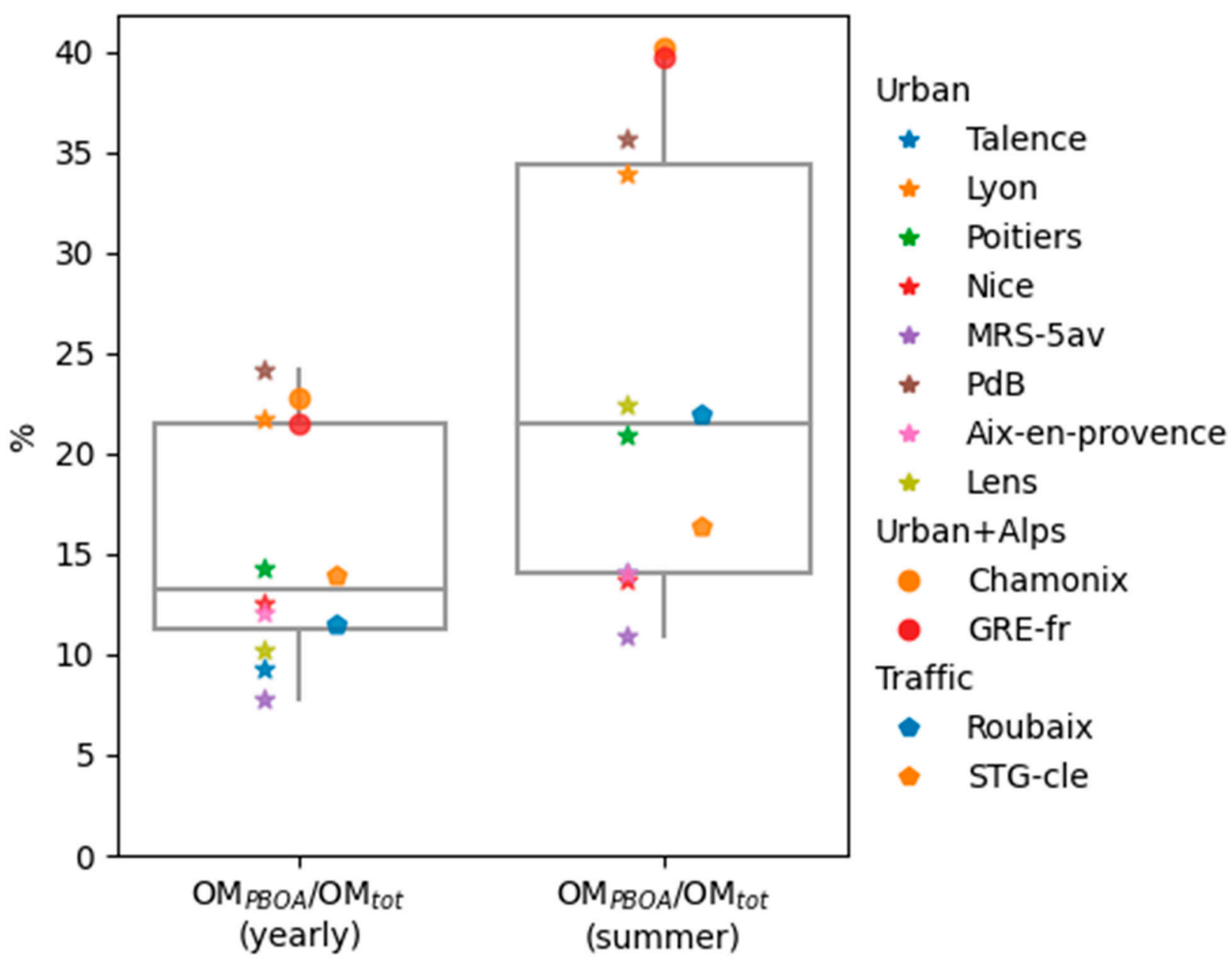

Figure 14. Annual mean and summer-averaged contribution of PBOA to total OM concentrations at various French urban sites.

\section{Sea Salts}

At the global scale, sea salts represent the second largest contributor to the total aerosol burden in the atmosphere (after mineral dust), playing a key role in the overall water cycle, and possibly moderating climate change [6]. Logically, they can then make up another large fraction of natural aerosols observed in urban environments, mostly in the coarse PM mode. When located close to the shore, monitoring stations might even be over-influenced by these particles, which can also cause practical measurement issues related to their high hygroscopicity and corrosivity [92].

Sea salts are primarily composed of $\mathrm{Cl}^{-}, \mathrm{Na}^{+}, \mathrm{SO}_{4}{ }^{2-}, \mathrm{Mg}^{2+}$, and $\mathrm{Ca}^{2+}$. However, they can rapidly age during transport, notably due to the mixing with anthropogenic emissions over lands or before reaching them. This phenomenon commonly induces chloride replacement by sulfate and nitrate via acid-base reactions, mainly in the coarse 
aerosol fraction. The mixing between sea spray and heavy fuel oil combustion residuese.g., emitted from shipping or industrial activities—also leads to the build-up of an aged sea-salt component detected in source apportionment studies through the presence of a few chemical species generally attributed to anthropogenic emissions, such as EC and $\mathrm{Ni}$ (see Figure 13) [36].

As illustrated in Appendix B, seasonal-average $\mathrm{Na}^{+}$concentrations up to $1 \mu \mathrm{g} / \mathrm{m}^{3}$ are observed along all coastlines of the French metropolitan territory (i.e., the Atlantic Ocean, the English Channel, and the Mediterranean Sea), with large influences inland up to distances of several hundreds of $\mathrm{km}$. Lowest concentrations are detected in the most eastern part of France and in Alpine valleys. A well-marked seasonal cycle, with winter maxima, is observed at all sites located in northern France, whereas a reverse pattern tends to be seen for southern regions. Finally, depending on air mass origins (and on the strength of the weather front in the westerlies over the Atlantic), high loading events can be observed, where daily average fresh + aged sea salt concentrations typically of 10-15 $\mu \mathrm{g} / \mathrm{m}^{3}$ are not uncommon up to a couple of hundreds $\mathrm{km}$ from the western coasts [36,42].

\section{Saharan Dust}

The French West Indies are regularly impacted by Saharan dust events from West Africa (Sahel) or North Africa (Sahara) between March and October [93]. These desert dust particles are transported by the trade winds across the Atlantic Ocean, reaching the Caribbean Sea in one to two weeks [94], resulting in ambient particles concentrations above the $\mathrm{PM}_{10} \mathrm{EU}$ air quality standards. This is the case, for instance, in Martinique Island where the $50 \mu \mathrm{g} / \mathrm{m}^{3}$ daily mean concentration threshold has been exceeded every year since 2005, except for 2008. In addition to their global climate and ecosystem impact [95], they have been associated with adverse health effects, including cardiorespiratory mortality and morbidity [96]. Recently, Viel et al. [97] also evidenced an increasing risk of preterm births with the levels of $\mathrm{PM}_{10}$ and the frequency of intense Saharan dust events over Guadeloupe Island.

In this context, filter samples collected in the French West Indies have been occasionally analyzed since 2010 in the frame of the CARA program, systematically indicating a predominant influence of Saharan dust during exceedances of the $\mathrm{PM}_{10}$ daily threshold value $[98,99]$. A more comprehensive study has been conducted for the year 2018, with daily $\mathrm{PM}_{10}$ filter sampled semi-continuously at five monitoring stations in Martinique Island [84]. More than 300 filters were then selected for extensive offline chemical characterization, during and out of $\mathrm{PM}_{10}$ daily threshold exceedances. Outcomes of this study notably indicate a homogeneous spatial distribution of the Saharan dust loadings during $\mathrm{PM}_{10}$ concentration peaks and confirm the major role played by natural particles (Saharan dust, but also relatively high sea salt background levels) onto air quality over the island.

Figure 15 summarized some of the results obtained from the PMF analysis conducted for the Renéville roadside monitoring station located in Fort-de-France (see Section 6). On average for daily $\mathrm{PM}_{10}$ concentrations above $50 \mu \mathrm{g} / \mathrm{m}^{3}$, Saharan dust represents about half of the $\mathrm{PM}_{10}$. It should be noted that this relative contribution raises up to more than $70 \%$ during the highest $\mathrm{PM}_{10}$ daily peaks (above $100 \mu \mathrm{g} / \mathrm{m}^{3}$ ). Here, measures taken towards the abatement of anthropogenic emissions will not lead to significant reduction of the number of days exceeding the $\mathrm{PM}_{10}$ threshold value. Nevertheless, this may help lower adverse health effects induced by the overall ambient aerosol burden.

Finally, it should be noticed that Saharan dust outbreaks also influence the French metropolitan territory, especially its southeastern part (e.g., [64,100]), although less impressively than in the French West Indies and more often evidenced in southern European countries [8,9]. 


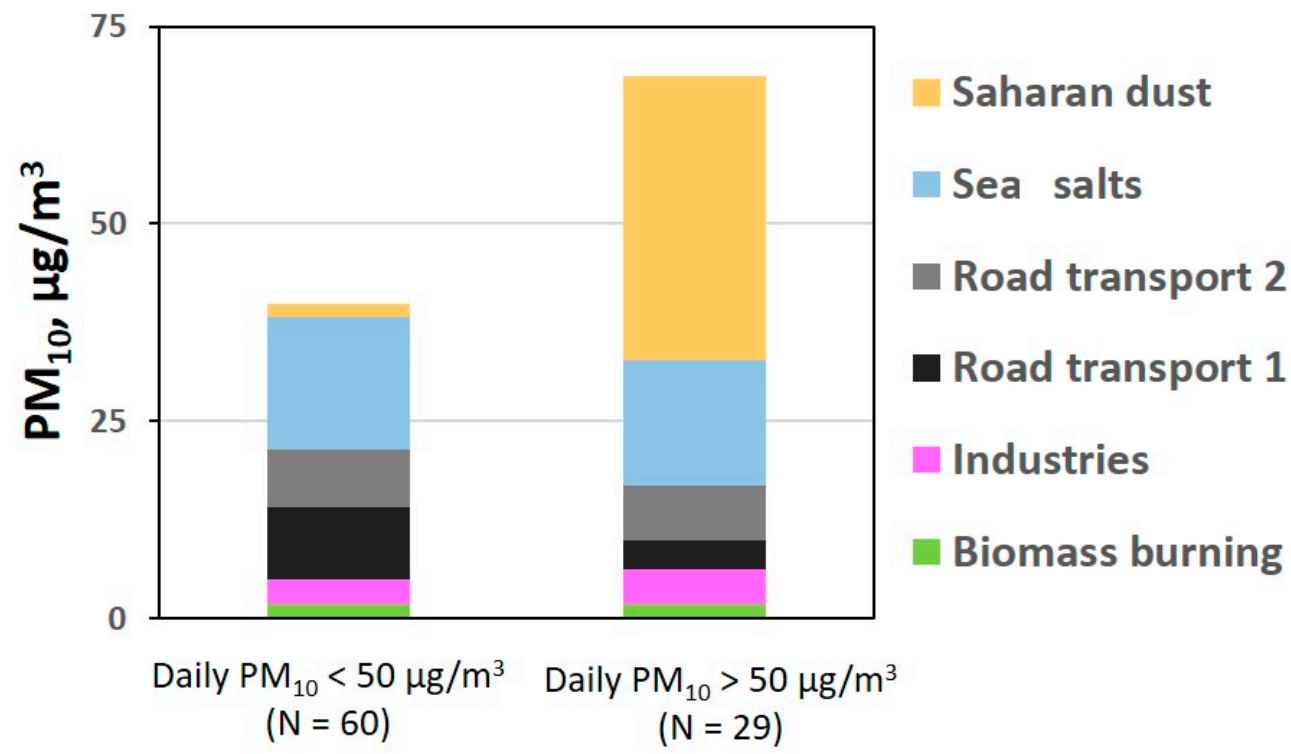

Figure 15. Contributions of the six factors obtained from the PMF analysis conducted for the urban traffic-oriented station of Fort-de-France (Renéville), out of and during PM $_{10}$ daily threshold exceedances, which could be investigated for 2018.

\section{Ammonium Nitrate}

In order to delineate the sources of nitrogen species during springtime PM pollution episodes dominated by ammonium nitrate (see Section 4.3), we tried to perform isotopic measurements of nitrogen, conducted separately on nitrate and ammonium [101,102]. Indeed, it is known that $\mathrm{N}$ produced during biological processes is depleted in heavy isotopes compared to atmospheric $\mathrm{N}[103,104]$. This may be a way to identify the source of $\mathrm{N}$ coming from enhanced ammonia emissions in late-winter/early-spring due to agricultural manure spreading [105]. This was notably performed within the INACS research project, notably taking advantage of yearly semi-continuous series of filter samples collected in the frame of the CARA program [106]. Obtained results are exemplified here with the case of Lyon, including a persistent large-scale pollution episode in spring 2012 (Figure 16). It clearly shows a strong depletion in $\delta^{15} \mathrm{~N}$ of ammonium concomitant to a very large increase of its concentrations during this overall episode, underlining the strong impact of the agricultural source with biological ammonia fertilizers during this type of event.

More surprisingly, relatively low ammonium concentrations recorded during the rest of the year reveal to be mainly influenced by other types of ammonia sources (with much higher $\delta^{15} \mathrm{~N}$ values). This might be related to the importance of still poorly documented specific urban emitters, such as vehicular exhaust and garbage piling, and subsequent rapid formation of ammonium nitrate at the local scale [67,107].

Nevertheless, long-range transport of ammonium nitrate from the continental sector has often been evidenced, notably using backward air mass trajectory analyses or CTMs $[29,108]$. To illustrate such a phenomenon, a comprehensive trajectory analysis has been carried out here using ACSM datasets available over the years covering the 2016-2017 period (corresponding to data collected at SIRTA, Creil, Metz, Poitiers, Bordeaux, Lyon, and Marseille stations).

The analysis consisted in the combination of single site concentration-weighted trajectory analyses using the ZeFir software package [109], as already performed and explained in [110] to investigate particulate sulfate formation from $\mathrm{SO}_{2}$ volcanic emissions. Briefly, the HYSPLIT model [111] was used to calculate 5-day back-trajectories every $6 \mathrm{~h}$, from $1^{\circ} \times 1^{\circ}$ Global Data Assimilation System (GDAS) files. Trajectory endpoints were discarded if significant precipitation occurred $(>1 \mathrm{~mm} / \mathrm{h})$. Finally, a sigmoidal weighing function was applied on the multi-site results in order to down-weight grid cells with low trajectory 
density. For nitrate, this analysis reveals hotspots mainly located in central Europe, northern Italy, and the Benelux regions (Figure 17a), in good agreement with previous studies focusing on shorter time periods and/or for a given receptor urban area (e.g., $[29,36,41])$.

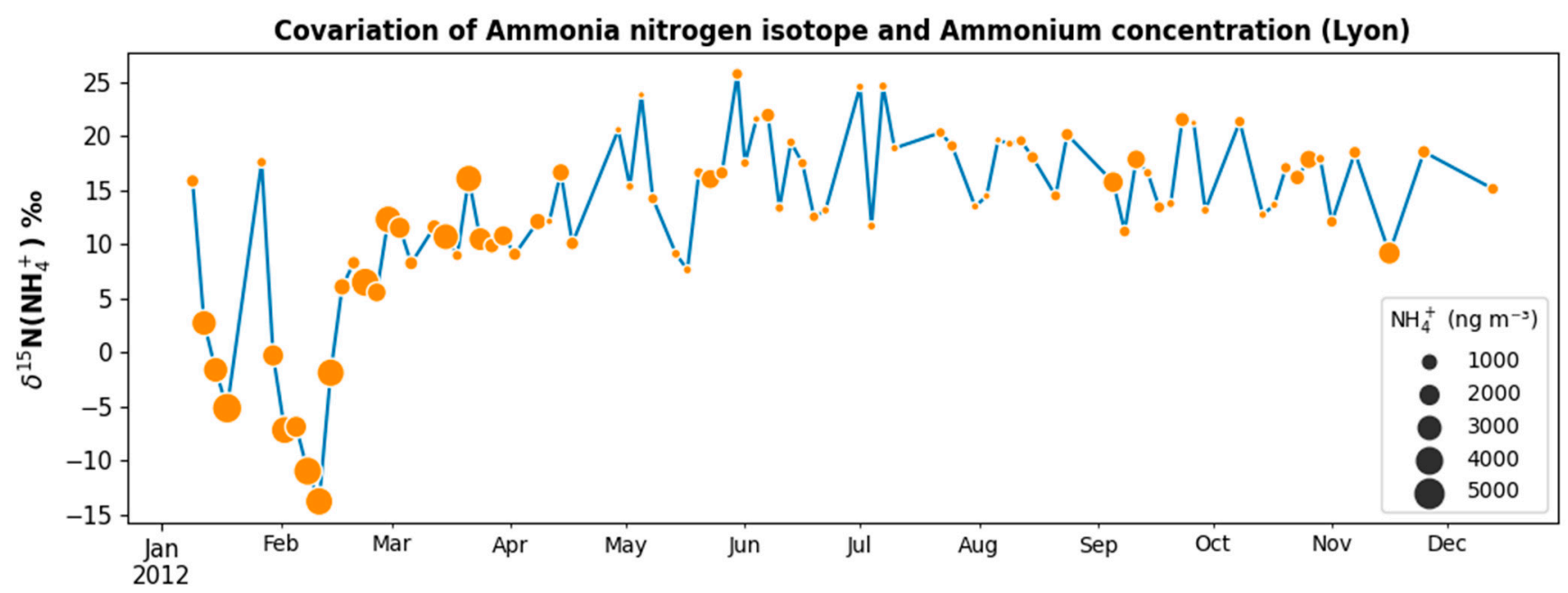

Figure 16. $\delta^{15} \mathrm{~N}$ and ammonium concentration time series in Lyon (urban background station, city center) in 2012.
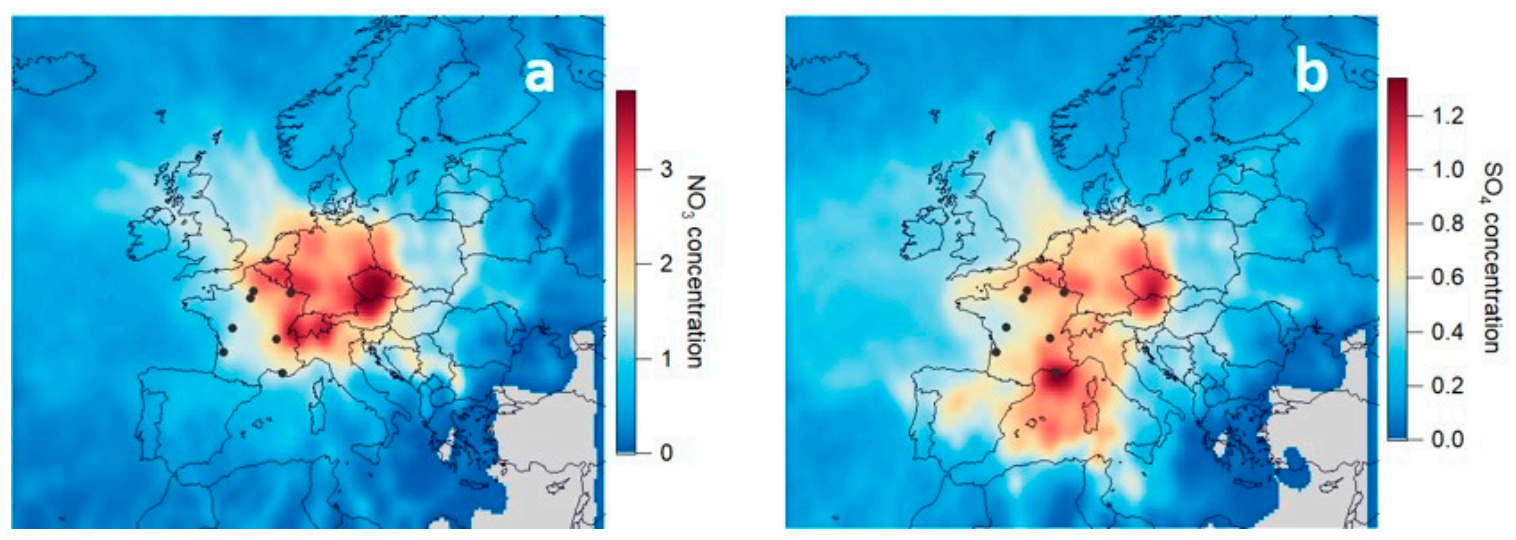

Figure 17. Multi-site concentration-weighted trajectory analysis of particulate nitrate (a) and sulfate (b) measured by ACSM in 2016-2017 at different CARA stations (SIRTA, Creil, Metz, Poitiers, Bordeaux, Lyon, and Marseille, black dots).

\section{Ammonium Sulfate}

The same analysis was performed for sulfate concentrations, also known to be highly influenced by long-range advection from continental Europe, at least for northern France [28,36]. As for nitrate, central Europe and the Benelux regions, corresponding to abundant $\mathrm{SO}_{2}$ emissions [112], are also clearly captured (Figure 17b). Additional regions are also highlighted in the Mediterranean and-less importantly-the Channel areas, suggesting a substantial role of shipping emissions. Marseille represents here a peculiar case with a clear hotspot, probably also related to intense industrial and petrochemical activities [113]. Indeed, Marseille is directly downwind of the large Fos-Berre petrochemical area (located $40 \mathrm{~km}$ away from city center, at its northwestern side) and the city harbor basins. Depending on the wind direction, the urban background site is frequently impacted by industrial and shipping traffic plumes [114]. A typical summertime case study is provided below to exemplify this phenomenon. Figure 18 presents the temporal variation of the wind direction, of key chemical species concentrations $\left(\mathrm{OA}, \mathrm{SO}_{4}{ }^{2-}, \mathrm{NH}_{4}{ }^{+}, \mathrm{NO}_{3}{ }^{-}, \mathrm{Cl}^{-}\right.$, 
eBC, $\mathrm{V}, \mathrm{Ni}$ and $\mathrm{Pb}$ in the particulate phase, as well as $\mathrm{SO}_{2}$ ) and UFP (considered here in the 3-158 nm size range) concentration and size distribution.

Around 10:00 a.m. UTC, very intense plumes of $\mathrm{SO}_{2}$ associated with UFP, OA, and metals are observed when sea breeze sets in $\left(190-240^{\circ}\right)$, advecting air masses impacted by industrial and shipping emissions over the city. Several smallest plumes advection occurs through the day under this sea breeze system. These events are followed by enhanced ambient sulfate concentrations in the city center, assessed to originate from $\mathrm{SO}_{2}$ photochemical oxidation. Finally, in the evening (7:00 p.m./8:00 p.m. UTC), the land breeze brings back the processed air masses to the city, with another increase of sulfate loadings.

This example shows a large increase on short time scale of ammonium sulfate concentrations, in relation with emissions from heavy fuel oil combustion emissions (which can be traced by vanadium). Elevated concentrations of both sulfate and vanadium can also be seen on large temporal (yearly) and spatial (Mediterranean coastline from Nice to Port-de-Bouc) on the maps in Appendix B, with concentrations larger than anywhere else in France. Constraining the contribution of refineries and shipping emissions remains a tremendous challenge in this whole region.

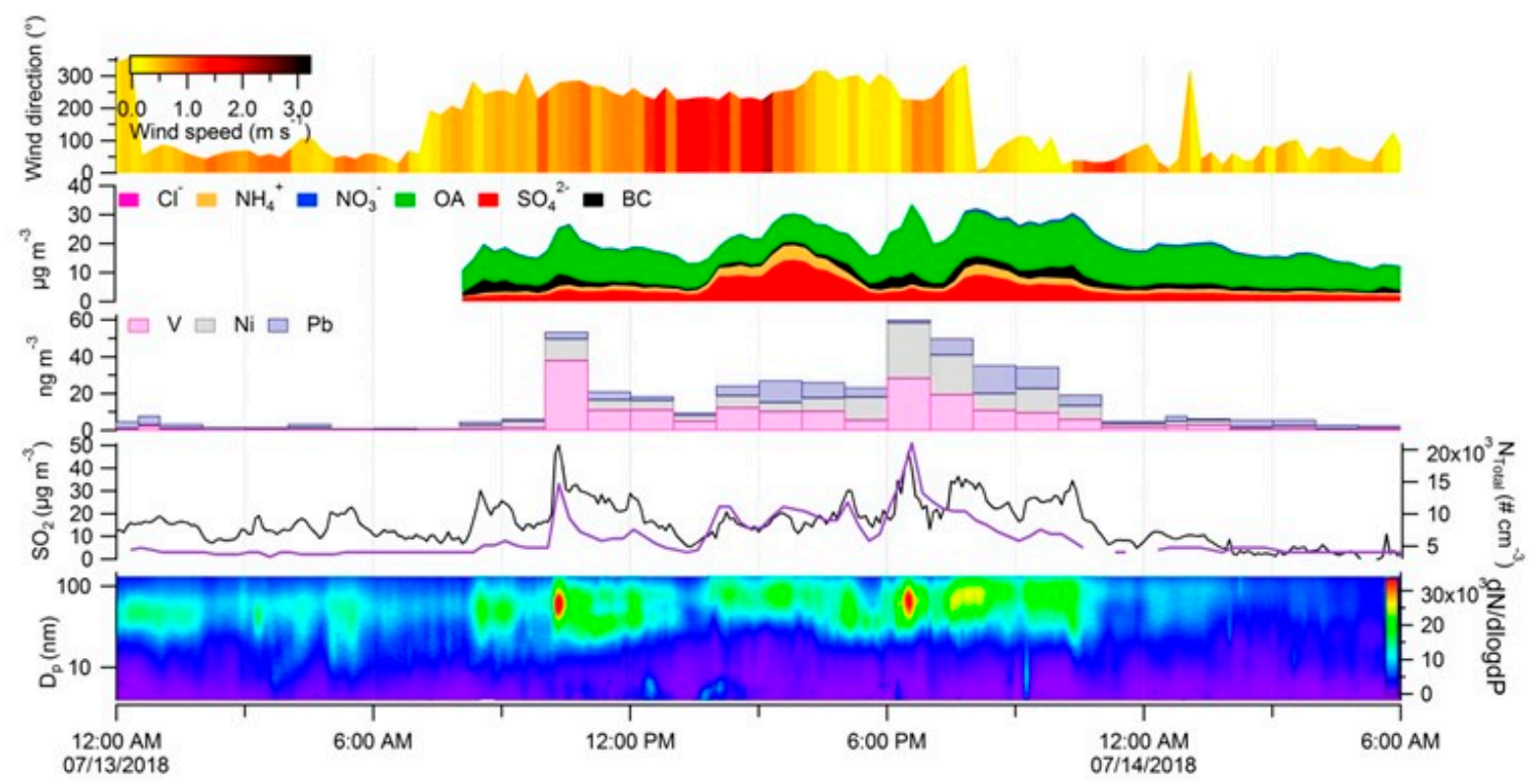

Figure 18. Time series of wind direction (color-coded by wind speed), Chemical species of $\mathrm{PM}_{1}\left(\mathrm{OA}, \mathrm{SO}_{4}{ }^{2-}, \mathrm{NH}_{4}{ }^{+}, \mathrm{NO}_{3}{ }^{-}\right.$, $\mathrm{Cl}^{-}$, and $\left.\mathrm{BC}\right)$, metals $(\mathrm{V}, \mathrm{Ni}$, and $\mathrm{Pb}), \mathrm{SO}_{2}$, total particle number and size distribution measured with a nanoSMPS (3-158 nm) during 13 July 2018, in Marseille.

\section{Secondary Organic Aerosols (SOA)}

Secondary organic aerosols are known to make up a very significant amount of OM, and then of PM, especially in the fine aerosol mode [39]. Yet, they are barely represented within the outputs of classical filter-based source apportionment studies. This is reflected in Figure 11 (for instance), where only one PMF factor (namely, marine SOA) is directly linked to its precursor and secondary origins (using MSA, which is already not so commonly used in such type of analysis). To bridge the gap between real-world atmospheric chemistry and receptor modeling results, increasing efforts have been made to determine molecular organic compounds, which can be identified as typical oxidation by-products of biogenic or anthropogenic SOA precursors and then used as specific markers in source apportionment studies $[20,115,116]$.

Recently, some of these SOA markers could be monitored offline at a couple of sites within the CARA program (i.e., Grenoble and SIRTA). Their use in PMF analysis allowed the deconvolution and apportionment of different SOA sources not commonly resolved 
in the literature, highlighting substantial contributions of specific biogenic and anthropogenic SOA factors $[18,20,21,117]$. More precisely, a peculiar secondary anthropogenic fraction could be evidenced in Grenoble, possibly related with Fenton-like chemistry and self-amplification cycle of SOA formation during wintertime PM pollution episodes [18]. At SIRTA, various anthropogenic SOA fractions could be linked to different secondary oxidation processes involving the following precursors: toluene and naphthalene, phenolic compounds, and PAHs (notably leading to the formation of DHOPA and phthalic acid, methylnitrocatechols and oxy/nitro-PAHs, respectively). These precursors are assumed to be mainly emitted by biomass burning and vehicular exhaust, and the sum of corresponding SOA loadings might represent up to $40 \%$ of daily $\mathrm{PM}_{10}$ concentrations in Greater Paris during the winter season $[21,117]$.

Regarding biogenic SOA, and besides the MSA-rich factor, one additional fraction could be attributed to the oxidation of alkenes (i.e., isoprene and terpenes) emitted by terrestrial vegetation at both sites, more importantly at summertime. Nevertheless, these PMF analyses did not allow to discriminate between both types of alkene byproducts, and then between VOC emissions from deciduous and resinous trees. This could be done for the SIRTA dataset using another type of source apportionment method, i.e., the so-called SOA-tracer method [115], which, in return, still needs fine optimizations to better account for anthropogenic SOA $[117,118]$. Further efforts are then required to refine the source apportionment of the various SOA fractions, along with other PM contributors, using receptor models. It should however be noted that the search for proper biogenic tracers implies very sensitive and labor-intensive (and then costly) offline chemical analyses [116], that may not be applied easily and routinely within operational networks.

On the other hand, classical source apportionment methods applied to AMS (or ACSM) organic mass spectra commonly reveals overwhelming contributions of different types of oxygenated organic aerosols (OOA), which are usually attributed to SOA $[119,120]$. While allowing for a specific discrimination of the full submicron OA burden, results obtained using such methodologies rarely consider interactions with inorganics and do not trivially link the different OOA fractions to specific SOA precursors and/or formation mechanisms. Advanced data treatment strategies combining OA mass spectra with datasets obtained from complementary co-located measurements could provide further insight into these PM origins (e.g., [120,121]). In particular, adding specific SOA markers to ACSM organic mass spectra proved to allow a better understanding of OA sources during a PM pollution events documented at SIRTA in March 2015. As detailed in [82], this novel methodology lead to the deconvolution of ten different PMF factors, among which, two could be clearly attributed to biogenic SOA, and four could be attributed to relatively fresh anthropogenic SOA fractions mainly linked to traffic and/or biomass burning emissions at the urban scale (as revealed by diel variations of these factors). These factors are gathered in Figure 19, according to the main origin of their precursors (i.e., biogenic vs. anthropogenic SOA), for a simpler comparison with the classical ACSM approach. Since it requires the offline chemical analysis of a limited number of key molecular markers only, such a source apportionment strategy might be applied regularly for the CARA program supersites to refine our knowledge on the origins of both the primary and secondary aerosol fractions. 
ACSM OA mass spectra, classical approach

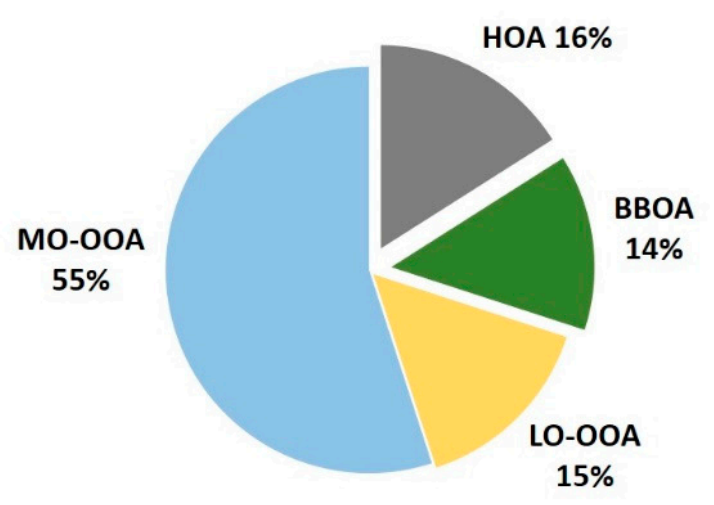

\section{Combined online-offline novel approach}

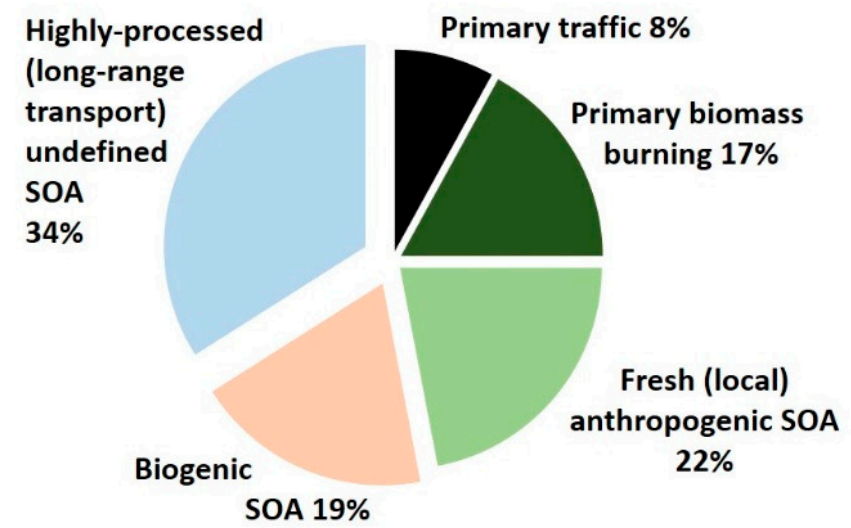

Figure 19. Comparison of PMF outputs obtained using a conventional approach applied to ACSM OA mass spectra and a novel methodology combining these mass spectra with key molecular markers in the PMF input data matrix. Adapted from Srivastava et al. [82].

\section{Conclusions and Perspectives}

This paper presents some of the main activities and results of the French CARA program, which has been running for more than ten years. Being operated in the field by regional air quality monitoring networks in close collaboration with the LCSQA (and other academic partners) for so long, this program is unique in Europe. It is designed on simple but robust methodologies to document the PM chemical composition and sources in urban environment. It also includes_or facilitates—state-of-the-art research activities, which, in turn, allow stepwise upgrades and optimization of conventional ambient air monitoring systems in France. In this regard, the CARA program may be considered as a pioneer operational tool for the implementation of European policy-driven air quality strategies.

This program is notably based on the application of sound QA/QC procedures, including ILC exercises for key measurement techniques. Initially developed for offline chemical analyses of daily $\mathrm{PM}_{10}$ samples collected quasi-continuously or during specific campaigns, it now also benefits from dense networks of AE33 and ACSM monitoring sites. These highly time-resolved and online measurements allow to extensively document the major chemical species that compose the fine aerosol mode. Moreover, they greatly help for a better understanding, in near-real time, of the main anthropogenic emission sources, of the potential influences of secondary processes and/or of geographical origins of PM pollution episodes. The fine aerosol mode being mainly influenced by anthropogenic pollutant emissions, this online monitoring set-up provide direct information to AASQAs (and to the LCSQA), which might then be considered by decision makers when it comes to implement and prioritize selected short-term legal decisions and long-term action plans.

Scientific results presented in this paper notably illustrate the predominant influences of (i) wintertime residential wood burning, and ii) year-long (exhaust and non-exhaust) vehicular emissions, on the overall urban air quality in France. They also exemplify the importance of additional sources at local scale (such as shipping and industrial emissions in Marseille) or during critical periods of the year (e.g., ammonia emission by agricultural activities under stable low-pressure meteorological systems in late-winter/early-spring). Moreover, recent works on natural particles evidenced the substantial contribution of PBOA in the coarse aerosol mode, especially in summer, as well as the overwhelming impacts of Saharan dust outbreaks on the $\mathrm{PM}_{10}$ limit value exceedances in the French West Indies. Furthermore, some efforts have been dedicated to the refinement of our knowledge on the origins of secondary species, notably using new organic molecular markers in receptor models. 
Development perspectives also comprise near-real time source apportionment methodologies, along with a wider characterization of the PM chemical and physical properties, as well as of inorganic gaseous precursors playing a prominent role in the formation of secondary aerosols. UFP (or, at least, total particle number concentration) and ammonia measurement systems are currently deployed by the AASQAs in a growing number of urban sites. Considering the oxidative potential, and probable associated health outcomes, of non-exhaust PM vehicular emissions [3], high time-resolved measurements of a wide range of heavy metals [122] should be envisaged in the near future. This would also greatly help for a better source apportionment of other types of mineral particles, which substantially contribute to the $\mathrm{PM}_{10}$ burden in urban areas.

These near-future milestones shall be elaborated and reinforced in synergetic approaches with European programs and research infrastructures. In particular, the ACTRIS has a vocation to provide guidance for the monitoring of novel air quality parameters in urban environments, including advanced in situ observations but also key remote sensing variables describing atmospheric dynamics. Closer interactions with the EMEP (and its French diversification, i.e., MERA) are also underway. In this regard, the transition of some offline monitoring site towards selected remote stations (which could also progressively host online instrumentation) has been decided in 2020. This will allow for a better characterization of (sub)regional background air quality and to set-up so-called "paired sites" strategies to refine the determination of long-range transport vs. local air pollution [10].

Finally, extended datasets and filter collections that have been gathered in the frame of the CARA program are already made available for complementary studies, such as comparison exercises between in situ observations and CTM outputs or remote sensing measurements (e.g., [105]), as well as cross-over studies on adverse health effects [3,25]. Such initiatives shall be further developed in a broader landscape (e.g., including near-real time data provision to the European Copernicus Programme), while continuous online measurements at multi-sites will also set the basis for achieving long-term investigations, such as epidemiological studies and air quality trend analyses.

Author Contributions: Conceptualization, O.F., C.M., and E.L.-G. for the CARA program, O.F. and J.-L.J. for the SOURCES project, O.F., J.-E.P., A.A., and V.G. for research activities at SIRTA, J.-L.J., J.-L.B. for DECOMBIO, J.-L.J. and S.C. for measurements at OPE; methodologies, O.F., S.W., J.-E.P., L.Y.A., A.A., V.R., A.P., N.B., J.-L.B., J.S., N.M., and J.-L.J.; software, S.W., J.-E.P., D.S. (Deepchandra Srivastava), and B.C.; validation, O.F., J.-E.P., L.Y.A., A.A., V.R., T.A., G.U., J.S., N.M., C.M., and J.-L.J.; investigation, O.F., S.W., J.-E.P., L.Y.A., A.A., V.R., B.C., D.S. (Dalia Salameh), Y.Z., D.S. (Deepchandra Srivastava), A.S., M.C., F.C., M.D.-S., and S.Z.; writing—original draft preparation, O.F. with valuable inputs from S.W., J.-E.P., L.Y.A., A.A., V.R., B.C., and J.-L.J.; writing-review, all co-authors. All authors have read and agreed to the published version of the manuscript.

Funding: This work has been mainly funded by the French Ministry of Environment via its annual financial supports to the LCSQA, to the AASQAs, and to INERIS research programs. It has also been partially funded by ADEME (notably for the SOURCES project, under grant agreement 1462C0064, and for the DECOMBIO (1362C0028), PM-DRIVE (1162C0002), CAMERA (1062c0008), INACS (1262c0011), and QAMECS (1262c0011) programs), as well as by targeted initiatives led by the AASQAs, and by ANDRA. Offline chemical analyses are also supported at IGE by the Air-O-Sol platform with Labex OSUG@2020 (ANR10 LABX56) fundings and at IMT LD by the Labex CaPPA (ANR-11-LABX-0005-01) and CPER CLIMIBIO projects (also supporting ACSM and AE33 measurements at Lille supersite). Measurements at SIRTA have been partially supported by CNRS, CEA, and ACTRIS-France (notably through the CLAP national observation service). They were also part of the EUFP7 and H2020 ACTRIS projects (grant agreements Nos. 262254 and 654109). Finally, the PhD of Samuël Weber was funded by ENS Paris.

Data Availability Statement: Most of the filter-based PMF datasets and outputs are available at: http:/ / pmsources.u-ga.fr. Other data available on request.

Acknowledgments: The authors acknowledge the precious works in the field and/or in the lab over the last decade of so many technicians, engineers, and students from AASQAs, INERIS, IMT LD, IGE, and LSCE, who we prefer not to try and mention individually here, fearing we might 
unfortunately miss some of them. We strongly hope they may all recognize themselves and accept our warm acknowledgements. Greetings and personal supports from various individuals at funding and leading institutes are also highly appreciated.

Conflicts of Interest: The authors declare no conflict of interest. 


\section{Appendix A}

Table A1. Stations of the CARA program and complementary projects.

\begin{tabular}{|c|c|c|c|c|c|c|c|}
\hline Urban Area & Station Name & Operator & Site Type & Airbase ID & Filter Sampling Dates and Mode & ACSM & AE33 \\
\hline Lille & Roubaix-Serre & Atmo HdF & Traffic & FR11034 & 2013-2017: Quasi-continuous & & \\
\hline Lille & Leeds & Atmo HdF & Traffic & FR11007 & & & 2016-p \\
\hline Lille & Fives & Atmo HdF & Urban bckgd & FR11025 & & & 2015-p \\
\hline Lens & Services & Atmo HdF & Urban bckgd & FR28002 & 2008-2011: Quasi-continuous & & \\
\hline Lens & Stade & Atmo HdF & Urban bckgd & FR28131 & 2012-2017: Quasi-continuous & & \\
\hline Creil & Faïencerie & Atmo HdF & Urban bckgd & FR18043 & 2013: Campaign & $2015-p$ & 2015-p \\
\hline Creil & Nogent sur Oise & Atmo HdF & Peri-urban & FR18019 & 2013-2017: Quasi-continuous & & \\
\hline Paris & Gennevilliers & Airparif & Urban bckgd & FR04002 & 2016-17: Campaign & 2015-19 & 2015-p \\
\hline Paris & Paris 13 & Airparif & Urban bckgd & FR04037 & & & $2015-p$ \\
\hline Paris & Les Halles & Airparif & Urban bckgd & FR04055 & & 2019-p & 2019-p \\
\hline Paris & Bvd Haussmann & Airparif & Traffic & FR04131 & & & 2015-p \\
\hline Paris & Autoroute A1 & Airparif & Traffic & FR04058 & & & 2015-19 \\
\hline Paris & Periph. Auteuil & Airparif & Traffic & FR04053 & 2009-2013: Campaigns & & \\
\hline Paris & Periph. Est & Airparif & Traffic & FR04329 & & 2019-p & 2015-p \\
\hline Paris (region) & SIRTA & LSCE \& Ineris & Peri-urban & ACTRIS & 2014-present: Campaigns & $2011-\mathrm{p}$ & 2013-p \\
\hline Orléans & La Source & Lig'air & Urban bckgd & FR34029 & 2016-present: Campaigns, MARGA & & $20^{\mathrm{r}}$ \\
\hline- & Revin & Atmo GE & Rural bckgd & FR14008 & 2010-present: Quasi-continuous & & \\
\hline Metz & Borny & Atmo GE & Urban bckgd & FR01012 & 2015-2016: Campaign & $2015-\mathrm{p}$ & 2014-p \\
\hline Strasbourg & Clemenceau & Atmo GE & Traffic & FR16034 & 2011-present: Quasi-continuous & 2019-20 & 2019-p \\
\hline Strasbourg & Danube & Atmo GE & Urban bckgd & FR42010 & & $2018-p$ & 2018-p \\
\hline Mulhouse & Mulhouse Nord & Atmo GE & Urban bckgd & FR16057 & 2008-2012: Quasi-continuous & & \\
\hline- & OPE & ANDRA & Remote & (EMEP) & 2011-p: Campaigns & & 2018-p \\
\hline \multicolumn{2}{|c|}{ Belfort-Montbéliard (8 sites) } & Atmo BFC & various & & 2011-13: (Intensive) Campaigns & & 2018-p \\
\hline Dijon & Pejoces & Atmo BFC & Traffic & FR26005 & 2018-present: Campaigns & & 2019-p \\
\hline Rennes & Pays-Bas & Air Breizh & Urban bckgd & FR17019 & & $2020-p$ & 2019-p \\
\hline Nantes & Cim. Bouteillerie & Air PL & Urban bckgd & FR23188 & 2015-present: Quasi-continuous & & 2015-p \\
\hline Poitiers & Augouard & Atmo NA & Urban bckgd & FR09404 & 2015-present: Quasi-continuous & $2015-p$ & 2015-p \\
\hline Limoges & Berland & Atmo NA & Urban bckgd & FR87085 & 2018-present: Quasi-continuous & & $2018-p$ \\
\hline Bordeaux & Talence & Atmo NA & Urban bckgd & FR31002 & 2008-present: Quasi-continuous & 2015-p & 2014-p \\
\hline
\end{tabular}


Table A1. Cont.

\begin{tabular}{|c|c|c|c|c|c|c|c|}
\hline Urban Area & Station Name & Operator & Site Type & Airbase ID & Filter Sampling Dates and Mode & ACSM & AE33 \\
\hline Clermont-Fd & Montferrand & Atmo AuRA & Urban bckgd & FR07004 & & & $2015-\mathrm{p}$ \\
\hline Lyon & Lyon Centre & Atmo AuRA & Urban bckgd & FR20062 & 2008-present: Quasi-continuous & $2015-p$ & $2014-\mathrm{p}$ \\
\hline Lyon & Jean Jaures & Atmo AuRA & Traffic & FR20070 & & & $2018-\mathrm{p}$ \\
\hline Grenoble & Rondeau & Atmo AuRA & Traffic & FR15039 & 2013: Intensive campaign & & \\
\hline Grenoble & Caserne de Bonne & Atmo AuRA & Urban bckgd & FR15049 & & & $2017-p$ \\
\hline Chamonix * & & Atmo AuRA & Urban bckgd & FR33120 & 2013-15: Campaign & & $2013-\mathrm{p}$ \\
\hline Passy * & & Atmo AuRA & Urban bckgd & FR33220 & 2013-15: Campaign & & $2013-\mathrm{p}$ \\
\hline \multicolumn{2}{|c|}{$\begin{array}{c}\text { Marnaz * } \\
\text { Toulouse/Tarbes }\end{array}$} & Atmo Occitanie & Urban bckgd & FR12030/27 & 2013: Campaign & & \\
\hline Nice & Arson & Atmo Sud & Urban bckgd & FR24036 & 2014-2016: Quasi-continuous & & 2014-p \\
\hline Aix-en-Pvce & Ecole d'Art & Atmo Sud & Urban bckgd & FR03029 & 2015-2016: Quasi-continuous & & \\
\hline Marseille & Longchamps & Atmo Sud & Urban bckgd & FR03043 & 2014-2016: Quasi-continuous & 2017-p & 2014-p \\
\hline Marseille & Marignane & Atmo Sud & Urban bckgd & FR02043 & & & $2019-\mathrm{p}$ \\
\hline Port-de-Bouc & Lecque & Atmo Sud & Urban bckgd & FR02008 & 2014-2016: Quasi-continuous & & $2015-\mathrm{p}$ \\
\hline- & Venaco & Qualit'air Corse & Rural bckgd & FR41024 & 2013-2017: Campaigns & & \\
\hline \multicolumn{2}{|c|}{ Saint Pierre (Reunion island) } & ORA & Urban bckgd & FR38011/12 & 2011-2012: Campaign & & \\
\hline Fort de France & Bishop & Madininair & Urban bckgd & FR39007 & 2010-2014: Campaigns & & \\
\hline \multicolumn{2}{|c|}{ Guadeloupe Island } & Gwad'air & various & & 2017-present: Campaigns & & \\
\hline \multicolumn{2}{|c|}{ Cayenne (French Guyana) } & Atmo Guyane & Urban bckgd & FR40004 & 2016-2017: Campaign & & \\
\hline
\end{tabular}

$\mathrm{p}=$ present; * DECOMBIO research project. 


\section{Appendix B}

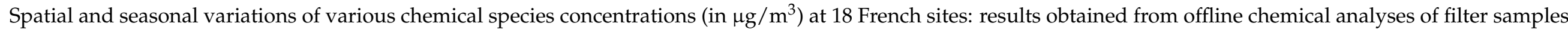
collected semi-continuously over at least one full year during the period 2012-2016 (Adapted from works presented in [16] and [42]).

Average oc concentration

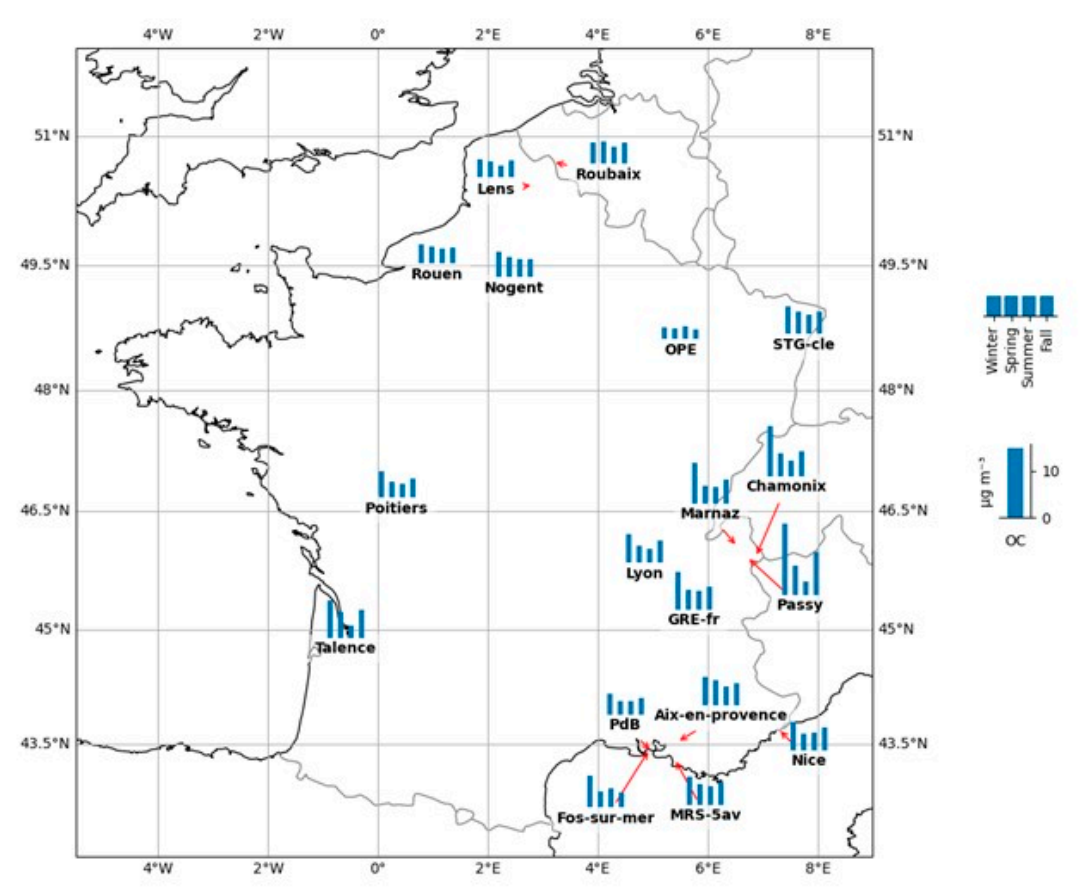

Average Levoglucosan concentration

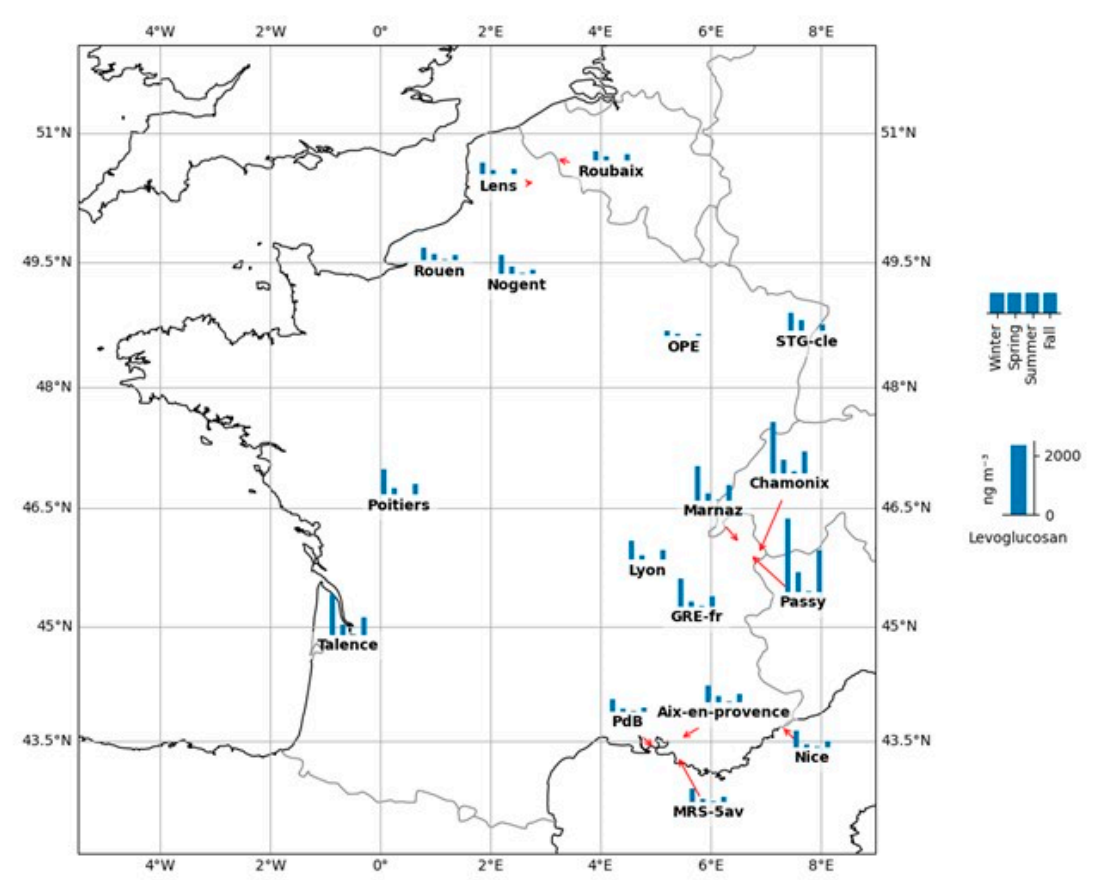


Average $\mathrm{NO}_{3}^{-}$concentration

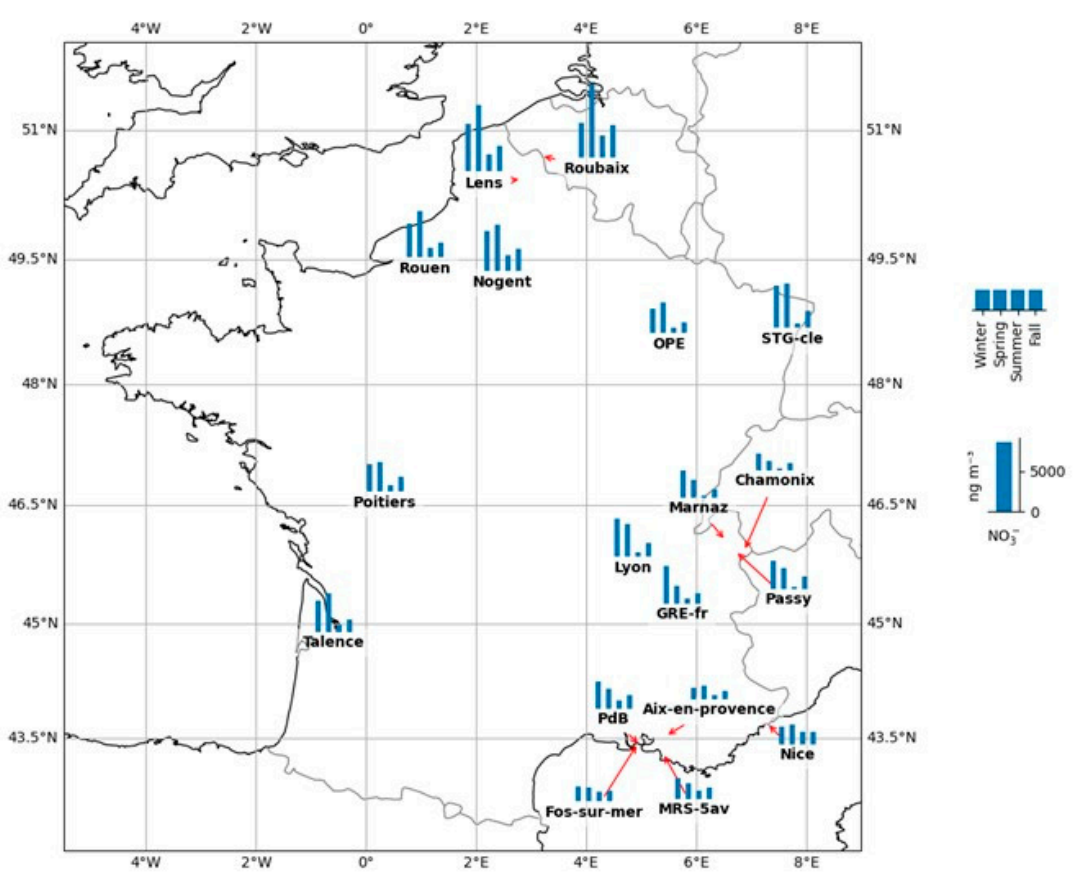

Average $\mathrm{SO}_{4}^{2-}$ concentration

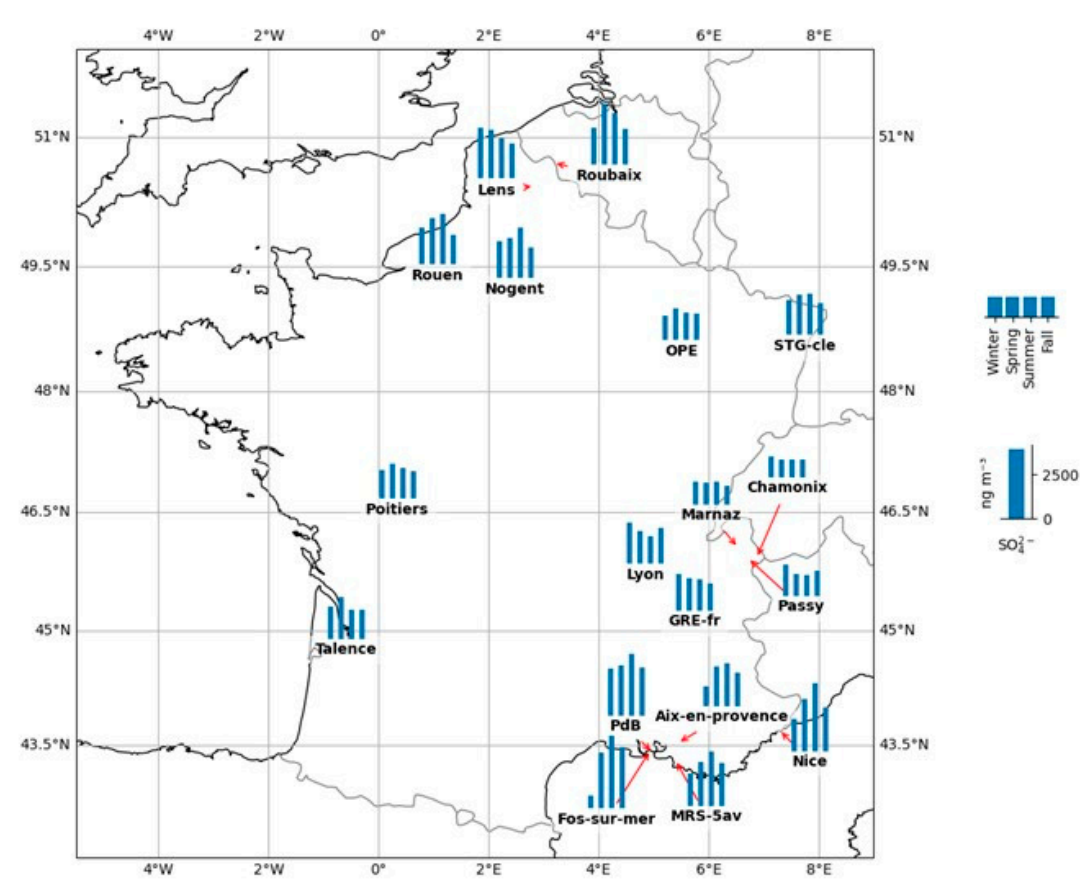


Average $\mathrm{Na}^{+}$concentration

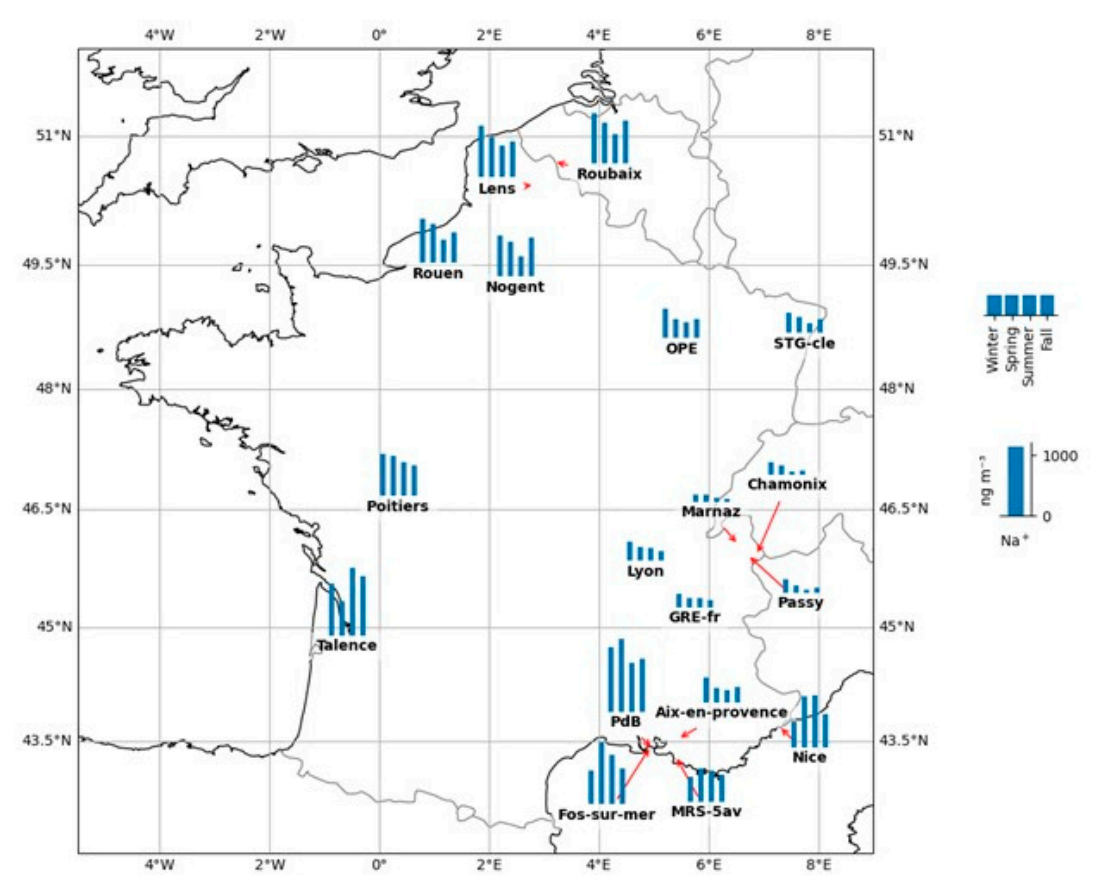

Average $\mathrm{Ca}^{2+}$ concentration

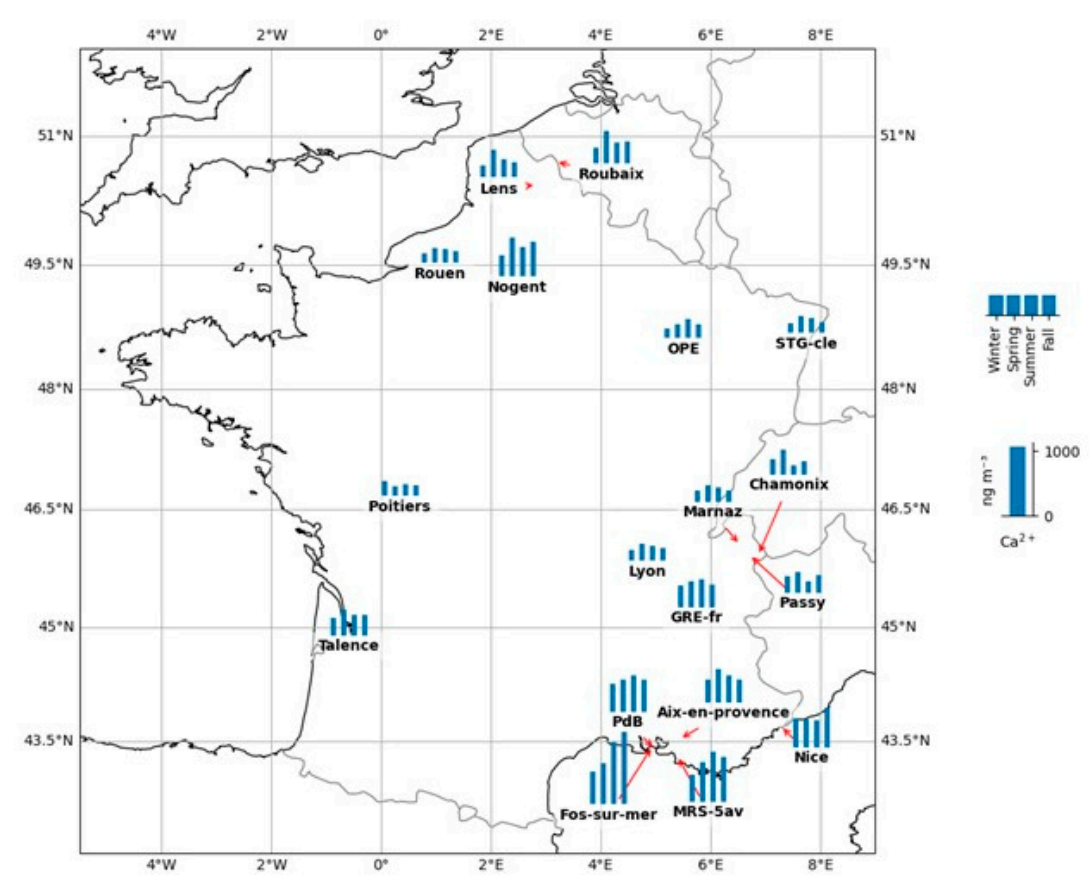


Average EC concentration

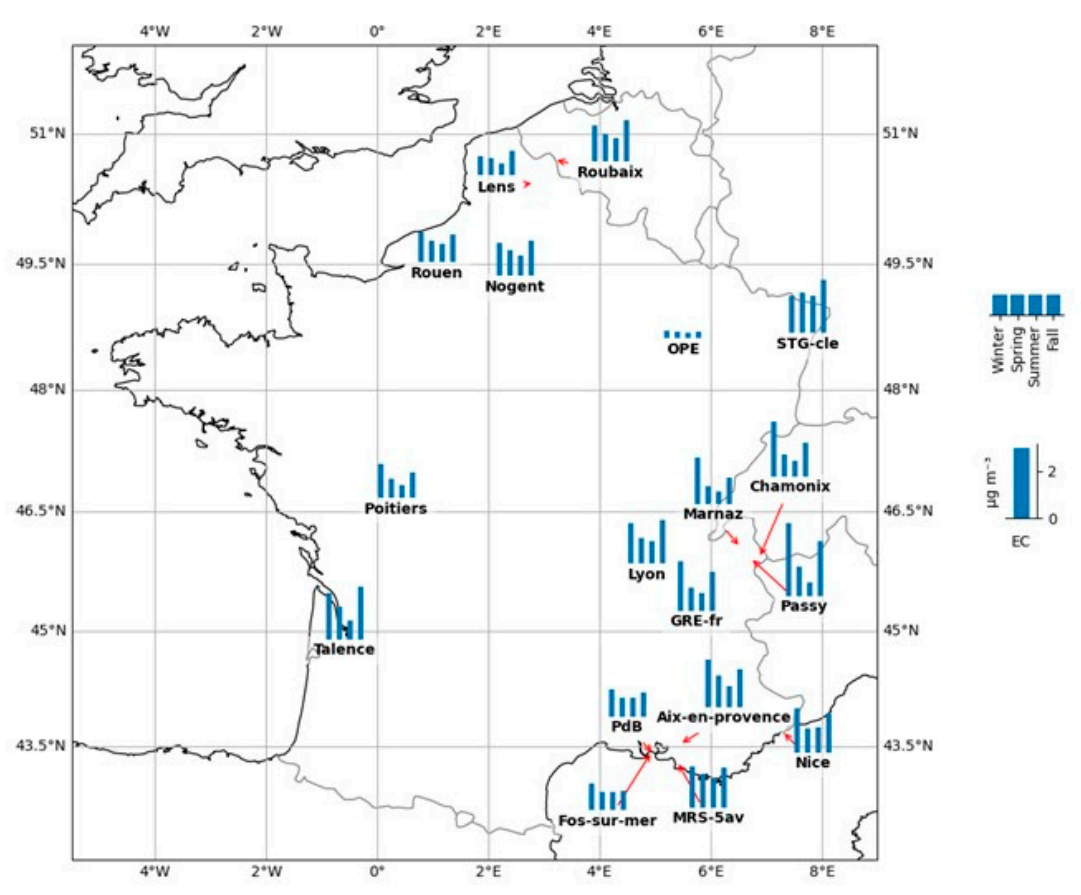

Average $\mathrm{Cu}$ concentration

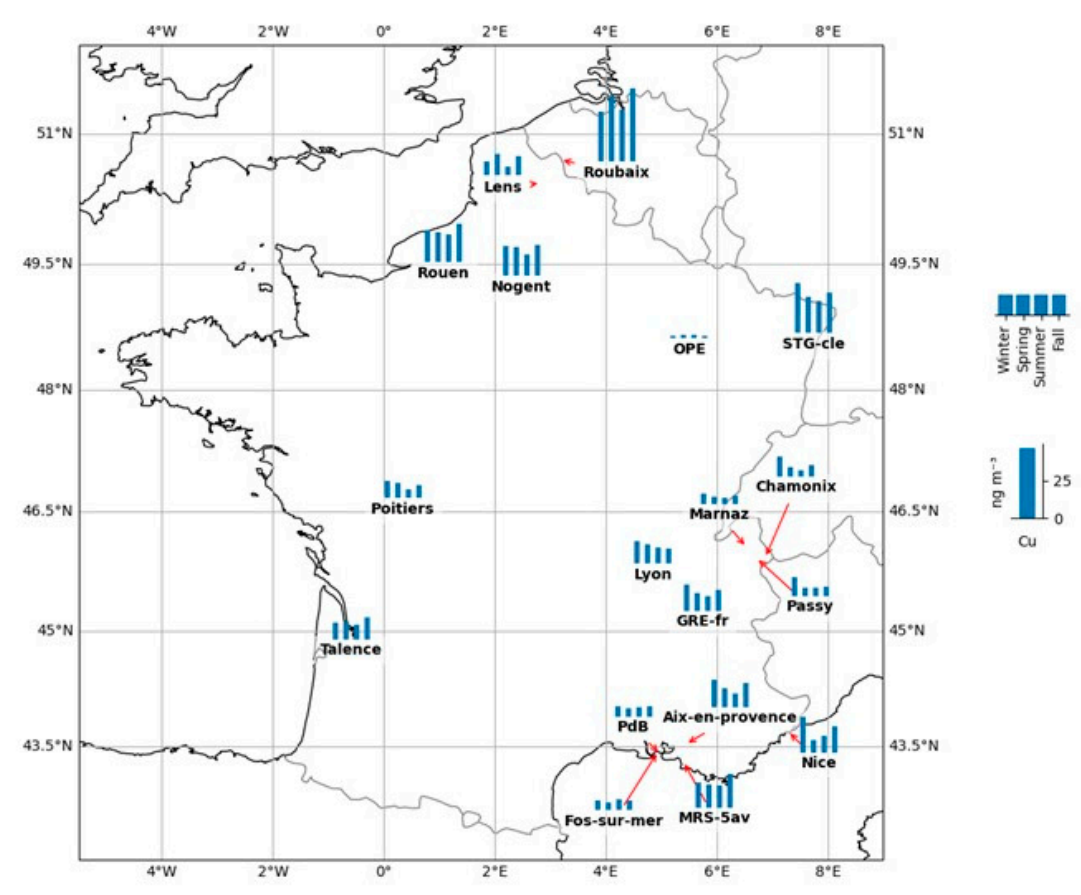


Average Fe concentration

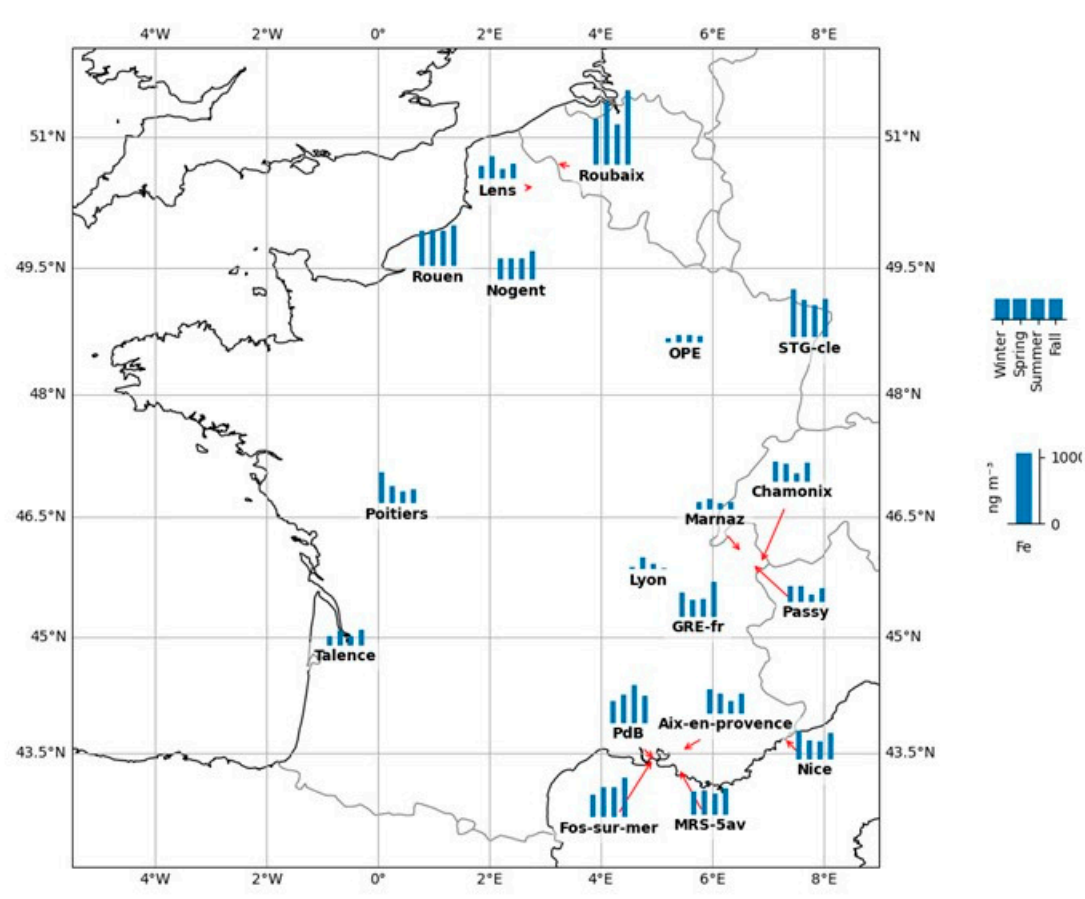

Average $\mathrm{V}$ concentration

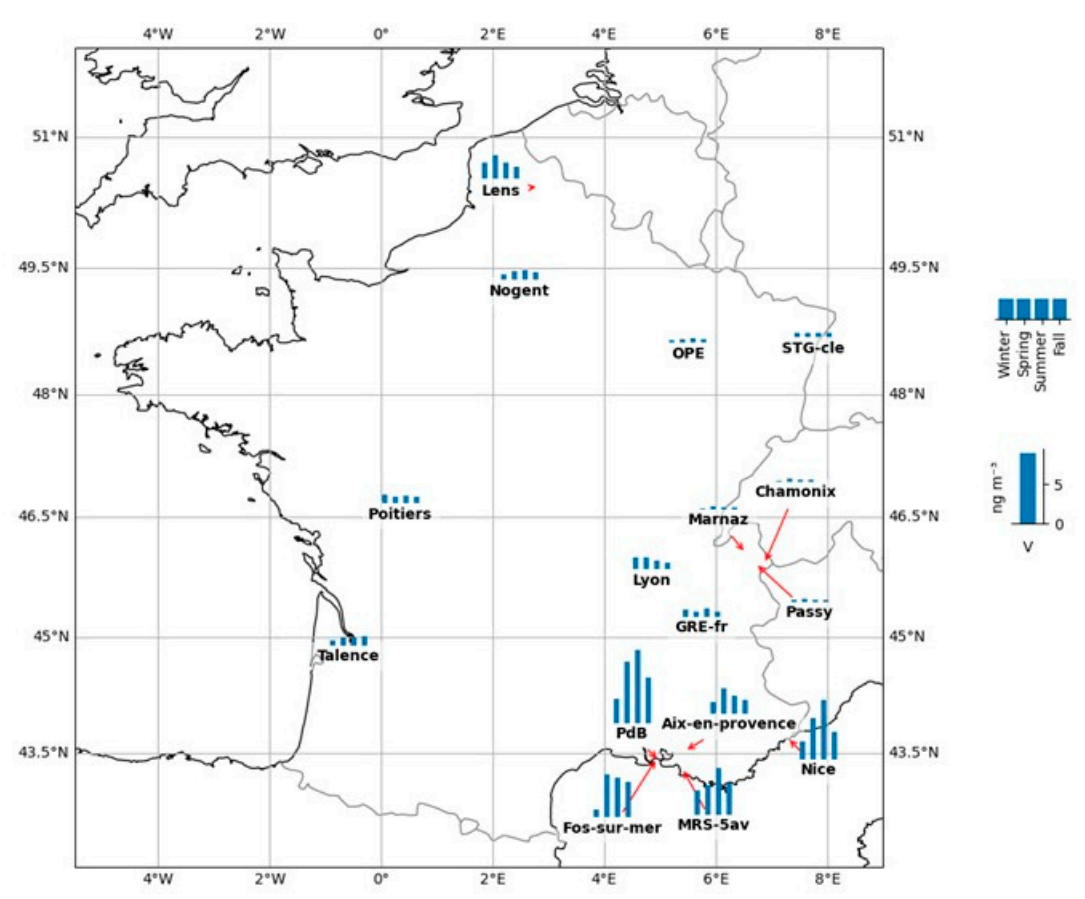




\section{References}

1. Beelen, R.; Raaschou-Nielsen, O.; Stafoggia, M.; Andersen, Z.J.; Weinmayr, G.; Hoffmann, B.; Wolf, K.; Samoli, E.; Fischer, P.; Nieuwenhuijsen, M.; et al. Effects of long-term exposure to air pollution on natural-cause mortality: An analysis of 22 European cohorts within the multicentre ESCAPE project. Lancet 2014, 383, 785-795. [CrossRef]

2. Cohen, A.J.; Brauer, M.; Burnett, R.; Anderson, H.R.; Frostad, J.; Estep, K.; Balakrishnan, K.; Brunekreef, B.; Dandona, L.; Dandona, R.; et al. Estimates and 25-year trends of the global burden of disease attributable to ambient air pollution: An analysis of data from the Global Burden of Diseases Study 2015. Lancet 2017, 389, 1907-1918. [CrossRef]

3. Daellenbach, K.R.; Uzu, G.; Jiang, J.; Cassagnes, L.-E.; Leni, Z.; Vlachou, A.; Stefenelli, G.; Canonaco, F.; Weber, S.; Segers, A.; et al. Sources of particulate-matter air pollution and its oxidative potential in Europe. Nature 2020, 587, 414-419. [CrossRef] [PubMed]

4. Favez, O.; Cachier, H.; Chabas, A.; Ausset, P.; Lefevre, R. Crossed optical and chemical evaluations of modern glass soiling in various European urban environments. Atmos. Environ. 2006, 40, 7192-7204. [CrossRef]

5. Holland, M.; European Environment Agency. Costs of Air Pollution from European Industrial Facilities 2008-2012: An Updated Assessment; Publications Office: Luxembourg, 2014; ISBN 978-92-9213-495-2.

6. Stocker, T.F.; Intergovernmental Panel on Climate Change (Eds.) Climate Change 2013: The Physical Science Basis. Part of the Working Group I Contribution to the Fifth Assessment Report of the Intergovernmental Panel on Climate Change; Intergovernmental Panel on Climate Change: New York, NY, USA, 2013; ISBN 978-92-9169-138-8.

7. Ministère de la Transition Ecologique, Service des Données et Etudes Statistiques. Bilan de la Qualité de L'air Extérieur en France en. 2019. Available online: https:/ / www.statistiques.developpement-durable.gouv.fr/bilan-de-la-qualite-de-lair-exterieur-enfrance-en-2019-0 (accessed on 2 February 2021).

8. Putaud, J.-P.; Raes, F.; Van Dingenen, R.; Brüggemann, E.; Facchini, M.-C.; Decesari, S.; Fuzzi, S.; Gehrig, R.; Hüglin, C.; Laj, P.; et al. A European aerosol phenomenology—2: Chemical characteristics of particulate matter at kerbside, urban, rural and background sites in Europe. Atmos. Environ. 2004, 38, 2579-2595. [CrossRef]

9. Alastuey, A.; Querol, X.; Aas, W.; Lucarelli, F.; Pérez, N.; Moreno, T.; Cavalli, F.; Areskoug, H.; Balan, V.; Catrambone, M.; et al. Geochemistry of PM10 over Europe during the EMEP intensive measurement periods in summer 2012 and winter 2013. Atmos. Chem. Phys. 2016, 16, 6107-6129. [CrossRef]

10. Pandolfi, M.; Mooibroek, D.; Hopke, P.; van Pinxteren, D.; Querol, X.; Herrmann, H.; Alastuey, A.; Favez, O.; Hüglin, C.; Perdrix, E.; et al. Long-range and local air pollution: What can we learn from chemical speciation of particulate matter at paired sites? Atmos. Chem. Phys. 2020, 20, 409-429. [CrossRef]

11. Pandolfi, M.; Alados-Arboledas, L.; Alastuey, A.; Andrade, M.; Angelov, C.; Artiñano, B.; Backman, J.; Baltensperger, U.; Bonasoni, P.; Bukowiecki, N.; et al. A European aerosol phenomenology—6: Scattering properties of atmospheric aerosol particles from 28 ACTRIS sites. Atmos. Chem. Phys. 2018, 18, 7877-7911. [CrossRef]

12. Laj, P.; Bigi, A.; Rose, C.; Andrews, E.; Lund Myhre, C.; Collaud Coen, M.; Lin, Y.; Wiedensohler, A.; Schulz, M.; Ogren, J.A.; et al. A global analysis of climate-relevant aerosol properties retrieved from the network of Global Atmosphere Watch (GAW) near-surface observatories. Atmos. Meas. Technol. 2020, 13, 4353-4392. [CrossRef]

13. LCSQA. Programme CARA: Bilan des Travaux de la Première Année (2008-2009). Available online: https://www.lcsqa.org/fr/ node/1586/printable/pdf (accessed on 2 February 2021).

14. Chevrier, F. Chauffage au Bois et Qualité de L'air en Vallée de l'Arve: Définition d'un Système de Surveillance et Impact d'une Politique de Rénovation du Parc des Appareils Anciens, Grenoble Alpes. Available online: https://www.semanticscholar.org/ paper/Chauffage-au-bois-et-qualit\%C3\%A9-de-1\%E2\%80\%99air-en-Vall\%C3\%A9e-de-Chevrier/704b4e34836d6a478b25fe5f5 $5253145 \mathrm{~b} 18639 \mathrm{fc}$ (accessed on 2 February 2021).

15. Bessagnet, B.; Menut, L.; Lapere, R.; Couvidat, F.; Jaffrezo, J.-L.; Mailler, S.; Favez, O.; Pennel, R.; Siour, G. High Resolution Chemistry Transport Modeling with the On-Line CHIMERE-WRF Model over the French Alps-Analysis of a Feedback of Surface Particulate Matter Concentrations on Mountain Meteorology. Atmosphere 2020, 11, 565. [CrossRef]

16. Golly, B.; Waked, A.; Weber, S.; Samake, A.; Jacob, V.; Conil, S.; Rangognio, J.; Chrétien, E.; Vagnot, M.-P.; Robic, P.-Y.; et al. Organic markers and OC source apportionment for seasonal variations of PM2.5 at 5 rural sites in France. Atmos. Environ. 2019, 198, 142-157. [CrossRef]

17. Farah, A.; Villani, P.; Rose, C.; Conil, S.; Langrene, L.; Laj, P.; Sellegri, K. Characterization of Aerosol Physical and Optical Properties at the Observatoire Pérenne de l'Environnement (OPE) Site. Atmosphere 2020, 11, 172. [CrossRef]

18. Srivastava, D.; Tomaz, S.; Favez, O.; Lanzafame, G.M.; Golly, B.; Besombes, J.-L.; Alleman, L.Y.; Jaffrezo, J.-L.; Jacob, V.; Perraudin, E.; et al. Speciation of organic fraction does matter for source apportionment. Part 1: A one-year campaign in Grenoble (France). Sci. Total Environ. 2018, 624, 1598-1611. [CrossRef] [PubMed]

19. Cavalli, F.; Viana, M.; Yttri, K.E.; Genberg, J.; Putaud, J.-P. Toward a standardised thermal-optical protocol for measuring atmospheric organic and elemental carbon: The EUSAAR protocol. Atmos. Meas. Tech. 2010, 3, 79-89. [CrossRef]

20. Borlaza, L.J.S.; Weber, S.; Uzu, G.; Jacob, V.; Cañete, T.; Favez, O.; Micallef, S.; Trébuchon, C.; Slama, R.; Jaffrezo, J.-L. Disparities in Particulate Matter (PM10) Origins and Oxidative Potential at a City-Scale (Grenoble, France)_Part I: Source Apportionment at Three Neighbouring Sites. Available online: https:/ / acp.copernicus.org/preprints/acp-2020-1144/acp-2020-1144.pdf (accessed on 2 February 2021). 
21. Srivastava, D.; Favez, O.; Bonnaire, N.; Lucarelli, F.; Haeffelin, M.; Perraudin, E.; Gros, V.; Villenave, E.; Albinet, A. Speciation of organic fractions does matter for aerosol source apportionment. Part 2: Intensive short-term campaign in the Paris area (France). Sci. Total Environ. 2018, 634, 267-278. [CrossRef] [PubMed]

22. Samaké, A.; Jaffrezo, J.-L.; Favez, O.; Weber, S.; Jacob, V.; Albinet, A.; Riffault, V.; Perdrix, E.; Waked, A.; Golly, B.; et al. Polyols and glucose particulate species as tracers of primary biogenic organic aerosols at 28 French sites. Atmos. Chem. Phys. 2019, 19, 3357-3374. [CrossRef]

23. Albinet, A.; Nalin, F.; Tomaz, S.; Beaumont, J.; Lestremau, F. A simple QuEChERS-like extraction approach for molecular chemical characterization of organic aerosols: Application to nitrated and oxygenated PAH derivatives (NPAH and OPAH) quantified by GC-NICIMS. Anal. Bioanal. Chem. 2014, 406, 3131-3148. [CrossRef]

24. Panteliadis, P.; Hafkenscheid, T.; Cary, B.; Diapouli, E.; Fischer, A.; Favez, O.; Quincey, P.; Viana, M.; Hitzenberger, R.; Vecchi, R.; et al. ECOC comparison exercise with identical thermal protocols after temperature offset correction-Instrument diagnostics by in-depth evaluation of operational parameters. Atmos. Meas. Technol. 2015, 8, 779-792. [CrossRef]

25. Calas, A.; Uzu, G.; Besombes, J.-L.; Martins, J.M.F.; Redaelli, M.; Weber, S.; Charron, A.; Albinet, A.; Chevrier, F.; Brulfert, G.; et al. Seasonal Variations and Chemical Predictors of Oxidative Potential (OP) of Particulate Matter (PM), for Seven Urban French Sites. Atmosphere 2019, 10, 698. [CrossRef]

26. Samaké, A.; Bonin, A.; Jaffrezo, J.-L.; Taberlet, P.; Weber, S.; Uzu, G.; Jacob, V.; Conil, S.; Martins, J.M.F. High levels of primary biogenic organic aerosols are driven by only a few plant-associated microbial taxa. Atmos. Chem. Phys. 2020, 20, 5609-5628. [CrossRef]

27. Colette, A.; Favez, O.; Meleux, F.; Chiappini, L.; Haeffelin, M.; Morille, Y.; Malherbe, L.; Papin, A.; Bessagnet, B.; Menut, L.; et al. Assessing in near real time the impact of the April 2010 Eyjafjallajökull ash plume on air quality. Atmos. Environ. 2011, 45, 1217-1221. [CrossRef]

28. Petit, J.-E.; Favez, O.; Sciare, J.; Crenn, V.; Sarda-Estève, R.; Bonnaire, N.; Močnik, G.; Dupont, J.-C.; Haeffelin, M.; Leoz-Garziandia, E. Two years of near real-time chemical composition of submicron aerosols in the region of Paris using an Aerosol Chemical Speciation Monitor (ACSM) and a multi-wavelength Aethalometer. Atmos. Chem. Phys. 2015, 15, 2985-3005. [CrossRef]

29. Petit, J.-E.; Amodeo, T.; Meleux, F.; Bessagnet, B.; Menut, L.; Grenier, D.; Pellan, Y.; Ockler, A.; Rocq, B.; Gros, V.; et al. Characterising an intense PM pollution episode in March 2015 in France from multi-site approach and near real time data. Atmos. Environ. 2017, 155, 68-84. [CrossRef]

30. Drinovec, L.; Močnik, G.; Zotter, P.; Prévôt, A.S.H.; Ruckstuhl, C.; Coz, E.; Rupakheti, M.; Sciare, J.; Müller, T.; Wiedensohler, A.; et al. The "dual-spot"; Aethalometer: An improved measurement of aerosol black carbon with real-time loading compensation. Atmos. Meas. Technol. 2015, 8, 1965-1979. [CrossRef]

31. Drinovec, L.; Gregorič, A.; Zotter, P.; Wolf, R.; Bruns, E.A.; Prévôt, A.S.H.; Petit, J.-E.; Favez, O.; Sciare, J.; Arnold, I.J.; et al. The filter-loading effect by ambient aerosols in filter absorption photometers depends on the coating of the sampled particles. Atmos. Meas. Technol. 2017, 10, 1043-1059. [CrossRef]

32. Sandradewi, J.; Prévôt, A.S.H.; Szidat, S.; Perron, N.; Alfarra, M.R.; Lanz, V.A.; Weingartner, E.; Baltensperger, U. Using Aerosol Light Absorption Measurements for the Quantitative Determination of Wood Burning and Traffic Emission Contributions to Particulate Matter. Environ. Sci. Technol. 2008, 42, 3316-3323. [CrossRef]

33. Ng, N.L.; Herndon, S.C.; Trimborn, A.; Canagaratna, M.R.; Croteau, P.L.; Onasch, T.B.; Sueper, D.; Worsnop, D.R.; Zhang, Q.; Sun, Y.L.; et al. An Aerosol Chemical Speciation Monitor (ACSM) for Routine Monitoring of the Composition and Mass Concentrations of Ambient Aerosol. Aerosol Sci. Technol. 2011, 45, 780-794. [CrossRef]

34. Freney, E.; Zhang, Y.; Croteau, P.; Amodeo, T.; Williams, L.; Truong, F.; Petit, J.-E.; Sciare, J.; Sarda-Esteve, R.; Bonnaire, N.; et al. The second ACTRIS inter-comparison (2016) for Aerosol Chemical Speciation Monitors (ACSM): Calibration protocols and instrument performance evaluations. Aerosol Sci. Technol. 2019, 53, 830-842. [CrossRef]

35. Guinot, B.; Cachier, H.; Oikonomou, K. Geochemical perspectives from a new aerosol chemical mass closure. Atmos. Chem. Phys. 2007, 7, 1657-1670. [CrossRef]

36. Waked, A.; Favez, O.; Alleman, L.Y.; Piot, C.; Petit, J.-E.; Delaunay, T.; Verlinden, E.; Golly, B.; Besombes, J.-L.; Jaffrezo, J.-L.; et al. Source apportionment of PM10 in a north-western Europe regional urban background site (Lens, France) using positive matrix factorization and including primary biogenic emissions. Atmos. Chem. Phys. 2014, 14, 3325-3346. [CrossRef]

37. Paatero, P.; Tapper, U. Positive matrix factorization: A non-negative factor model with optimal utilization of error estimates of data values. Environmetrics 1994, 5, 111-126. [CrossRef]

38. Karagulian, F.; Belis, C.A.; Dora, C.F.C.; Prüss-Ustün, A.M.; Bonjour, S.; Adair-Rohani, H.; Amann, M. Contributions to cities' ambient particulate matter (PM): A systematic review of local source contributions at global level. Atmos. Environ. 2015, 120, 475-483. [CrossRef]

39. Srivastava, D.; Favez, O.; Perraudin, E.; Villenave, E.; Albinet, A. Comparison of Measurement-Based Methodologies to Apportion Secondary Organic Carbon (SOC) in PM2.5: A Review of Recent Studies. Atmosphere 2018, 9, 452. [CrossRef]

40. Hopke, P.K.; Dai, Q.; Li, L.; Feng, Y. Global review of recent source apportionments for airborne particulate matter. Sci. Total Environ. 2020, 740, 140091. [CrossRef] [PubMed]

41. Petit, J.-E.; Pallarès, C.; Favez, O.; Alleman, L.Y.; Bonnaire, N.; Rivière, E. Sources and Geographical Origins of PM10 in Metz (France) Using Oxalate as a Marker of Secondary Organic Aerosols by Positive Matrix Factorization Analysis. Atmosphere 2019, 10, 370. [CrossRef] 
42. Weber, S.; Salameh, D.; Albinet, A.; Alleman, L.Y.; Waked, A.; Besombes, J.-L.; Jacob, V.; Guillaud, G.; Meshbah, B.; Rocq, B.; et al. Comparison of PM10 Sources Profiles at 15 French Sites Using a Harmonized Constrained Positive Matrix Factorization Approach. Atmosphere 2019, 10, 310. [CrossRef]

43. Belis, C.A.; Pernigotti, D.; Pirovano, G.; Favez, O.; Jaffrezo, J.L.; Kuenen, J.; Denier van Der Gon, H.; Reizer, M.; Riffault, V.; Alleman, L.Y.; et al. Evaluation of receptor and chemical transport models for PM10 source apportionment. Atmos. Environ. X 2020, 5, 100053. [CrossRef]

44. European Commission; Joint Research Centre. European Guide on Air Pollution Source Apportionment with Receptor Models: Revised Version 2019. Available online: https:/ / ec.europa.eu/jrc/en/publication/ european-guide-air-pollution-sourceapportionment-receptor-models (accessed on 2 February 2021).

45. Canonaco, F.; Crippa, M.; Slowik, J.G.; Baltensperger, U.; Prévôt, A.S.H. SoFi, an IGOR-based interface for the efficient use of the generalized multilinear engine (ME-2) for the source apportionment: ME-2 application to aerosol mass spectrometer data. Atmos. Meas. Tech. 2013, 6, 3649-3661. [CrossRef]

46. Zhang, Y.; Favez, O.; Petit, J.-E.; Canonaco, F.; Truong, F.; Bonnaire, N.; Crenn, V.; Amodeo, T.; Prévôt, A.S.H.; Sciare, J.; et al. Six-year source apportionment of submicron organic aerosols from near-continuous highly time-resolved measurements at SIRTA (Paris area, France). Atmos. Chem. Phys. 2019, 19, 14755-14776. [CrossRef]

47. Canonaco, F.; Tobler, A.; Chen, G.; Sosedova, Y.; Slowik, J.G.; Bozzetti, C.; Daellenbach, K.R.; ElHaddad, I.; Crippa, M.; Huang, R.J.; et al. A New Method for Long-Term Source Apportionment with Time-Dependent Factor Profiles and Uncertainty Assessment Using SOFI Pro: Application to One Year of Organic Aerosol Data. Available online: https://amt.copernicus.org/preprints/amt2020-204/ (accessed on 2 February 2021).

48. Petit, J.-E.; Favez, O.; Sciare, J.; Canonaco, F.; Croteau, P.; Močnik, G.; Jayne, J.; Worsnop, D.; Leoz-Garziandia, E. Submicron aerosol source apportionment of wintertime pollution in Paris, France by double positive matrix factorization (PMFxPMF) using an aerosol chemical speciation monitor (ACSM) and a multi-wavelength Aethalometer. Atmos. Chem. Phys. 2014, 14, 13773-13787. [CrossRef]

49. Dall'Osto, M.; Paglione, M.; Decesari, S.; Facchini, M.C.; O’Dowd, C.; Plass-Duellmer, C.; Harrison, R.M. On the Origin of AMS "Cooking Organic Aerosol" at a Rural Site. Environ. Sci. Technol. 2015, 49, 13964-13972. [CrossRef] [PubMed]

50. Favez, O.; Cachier, H.; Sciare, J.; Sarda-Estève, R.; Martinon, L. Evidence for a significant contribution of wood burning aerosols to PM2.5 during the winter season in Paris, France. Atmos. Environ. 2009, 43, 3640-3644. [CrossRef]

51. Favez, O.; El Haddad, I.; Piot, C.; Boréave, A.; Abidi, E.; Marchand, N.; Jaffrezo, J.-L.; Besombes, J.-L.; Personnaz, M.-B.; Sciare, J.; et al. Inter-comparison of source apportionment models for the estimation of wood burning aerosols during wintertime in an Alpine city (Grenoble, France). Atmos. Chem. Phys. 2010, 10, 5295-5314. [CrossRef]

52. El Haddad, I.; Marchand, N.; Dron, J.; Temime-Roussel, B.; Quivet, E.; Wortham, H.; Jaffrezo, J.L.; Baduel, C.; Voisin, D.; Besombes, J.L.; et al. Comprehensive primary particulate organic characterization of vehicular exhaust emissions in France. Atmos. Environ. 2009, 43, 6190-6198. [CrossRef]

53. Aiken, A.C.; DeCarlo, P.F.; Kroll, J.H.; Worsnop, D.R.; Huffman, J.A.; Docherty, K.S.; Ulbrich, I.M.; Mohr, C.; Kimmel, J.R.; Sueper, D.; et al. O/C and OM/OC Ratios of Primary, Secondary, and Ambient Organic Aerosols with High-Resolution Time-of-Flight Aerosol Mass Spectrometry. Environ. Sci. Technol. 2008, 42, 4478-4485. [CrossRef]

54. LCSQA. Impact de la Combustion de Biomasse sur les Concentrations de PM10 (Programme CARA-Hiver 2014-2015). Available online: https:/ / www.lcsqa.org/fr/rapport/2015/ineris/impact-combustion-biomasse-concentrations-pm10-programme-carahiver-2014-2015 (accessed on 2 February 2021).

55. LCSQA. Estimation des Concentrations de PM liées à la Combustion de Biomasse à Partir des Mesures D'absorption par le Brown Carbon. Available online: https:/ / www.lcsqa.org/fr/rapport/estimation-des-concentrations-de-pm-liees-la-combustion-debiomasse-partir-des-mesures (accessed on 2 February 2021).

56. Zhang, Y.; Albinet, A.; Petit, J.-E.; Jacob, V.; Chevrier, F.; Gille, G.; Pontet, S.; Chrétien, E.; Dominik-Sègue, M.; Levigoureux, G.; et al. Substantial brown carbon emissions from wintertime residential wood burning over France. Sci. Total Environ. 2020, 743, 140752. [CrossRef]

57. Chiappini, L.; Verlhac, S.; Aujay, R.; Maenhaut, W.; Putaud, J.P.; Sciare, J.; Jaffrezo, J.L.; Liousse, C.; Galy-Lacaux, C.; Alleman, L.Y.; et al. Clues for a standardised thermal-optical protocol for the assessment of organic and elemental carbon within ambient air particulate matter. Atmos. Meas. Technol. 2014, 7, 1649-1661. [CrossRef]

58. Simoneit, B.R.T.; Schauer, J.J.; Nolte, C.G.; Oros, D.R.; Elias, V.O.; Fraser, M.P.; Rogge, W.F.; Cass, G.R. Levoglucosan, a tracer for cellulose in biomass burning and atmospheric particles. Atmos. Environ. 1999, 33, 173-182. [CrossRef]

59. Puxbaum, H.; Caseiro, A.; Sánchez-Ochoa, A.; Kasper-Giebl, A.; Claeys, M.; Gelencsér, A.; Legrand, M.; Preunkert, S.; Pio, C. Levoglucosan levels at background sites in Europe for assessing the impact of biomass combustion on the European aerosol background. J. Geophys. Res. 2007, 112, D23S05. [CrossRef]

60. LCSQA. Interlaboratory Comparison Organized for the European Laboratories Involved in the Analysis of Levoglucosan and Its Isomers. Available online: https:/ / commons.datacite.org/doi.org/10.13140/rg.2.2.16262.47684 (accessed on 2 February 2021).

61. Louchouarn, P.; Kuo, L.-J.; Wade, T.L.; Schantz, M. Determination of levoglucosan and its isomers in size fractions of aerosol standard reference materials. Atmos. Environ. 2009, 43, 5630-5636. [CrossRef] 
62. Crenn, V.; Sciare, J.; Croteau, P.L.; Verlhac, S.; Fröhlich, R.; Belis, C.A.; Aas, W.; Äijälä, M.; Alastuey, A.; Artiñano, B.; et al. ACTRIS ACSM intercomparison-Part 1: Reproducibility of concentration and fragment results from 13 individual Quadrupole Aerosol Chemical Speciation Monitors (Q-ACSM) and consistency with co-located instruments. Atmos. Meas. Technol. 2015, 8, 5063-5087. [CrossRef]

63. LCSQA-AIRAQ-LGGE. Synthèse des Travaux 2013 du Programme CARA-Annexe A: Caractérisation des Particules sur L'agglomération Bordelaise. Available online: https://www.lcsqa.org/system/files/drc-13-136071-14096a-1csqa_2013 _metrologie_pm_cara_synthese.pdf (accessed on 2 February 2021).

64. Aymoz, G.; Jaffrezo, J.-L.; Jacob, V.; Colomb, A.; George, C. Evolution of organic and inorganic components of aerosol during a Saharan dust episode observed in the French Alps. Atmos. Chem. Phys. 2004, 4, 2499-2512. [CrossRef]

65. Bessagnet, B.; Menut, L.; Aymoz, G.; Chepfer, H.; Vautard, R. Modeling dust emissions and transport within Europe: The Ukraine March 2007 event. J. Geophys. Res. 2008, 113, D15202. [CrossRef]

66. Amato, F.; Favez, O.; Pandolfi, M.; Alastuey, A.; Querol, X.; Moukhtar, S.; Bruge, B.; Verlhac, S.; Orza, J.A.G.; Bonnaire, N.; et al. Traffic induced particle resuspension in Paris: Emission factors and source contributions. Atmos. Environ. 2016, 129, 114-124. [CrossRef]

67. Dall'Osto, M.; Harrison, R.M.; Coe, H.; Williams, P.I.; Allan, J.D. Real time chemical characterization of local and regional nitrate aerosols. Atmos. Chem. Phys. 2009, 9, 3709-3720. [CrossRef]

68. NILU. Evaluation of EMEP Trends Processed with Pyaerocom. Available online: https://actris.nilu.no/ content/?pageid=594ab0 6f0f324a32aa39e1c68d3250b6 (accessed on 2 February 2021).

69. Dupont, J.-C.; Haeffelin, M.; Badosa, J.; Elias, T.; Favez, O.; Petit, J.E.; Meleux, F.; Sciare, J.; Crenn, V.; Bonne, J.L. Role of the boundary layer dynamics effects on an extreme air pollution event in Paris. Atmos. Environ. 2016, 141, 571-579. [CrossRef]

70. LCSQA. Programmes de Recherche Expérimentaux pour L'étude des Sources de PM en Air Ambiant. Available online: https: //www.lcsqa.org/fr/rapport/2016/ineris/programmes-recherche-experimentaux-etude-sources-pm-air-ambiant (accessed on 2 February 2021).

71. Pandolfi, M.; Alastuey, A.; Pérez, N.; Reche, C.; Castro, I.; Shatalov, V.; Querol, X. Trends analysis of PM source contributions and chemical tracers in NE Spainduring 2004-2014: A multi-exponential approach. Atmos. Chem. Phys. 2016, 16, 11787-11805. [CrossRef]

72. LCSQA. Surveillance des Hydrocarbures AromatiquesPolycycliques (HAP). Available online: https://be.anses.fr/sites/default/ files/BEP-mg-BE18-art3.pdf (accessed on 2 February 2021).

73. Aymoz, G.; Jaffrezo, J.L.; Chapuis, D.; Cozic, J.; Maenhaut, W. Seasonal variation of PM10 main constituents in two valleys of the French Alps. I: EC/OC fractions. Atmos. Chem. Phys. 2007, 7, 661-675. [CrossRef]

74. LCSQA. Traitement Harmonisé de Jeux de Données Multi-Sites Pour L'étude de Sources de PM par Positive Matrix Factorization (PMF). Available online: https://www.lcsqa.org/en/node/1939/printable/pdf (accessed on 2 February 2021).

75. Salameh, D.; Pey, J.; Bozzetti, C.; El Haddad, I.; Detournay, A.; Sylvestre, A.; Canonaco, F.; Armengaud, A.; Piga, D.; Robin, D.; et al. Sources of PM2.5 at an urban-industrial Mediterranean city, Marseille (France): Application of the ME-2 solver to inorganic and organic markers. Atmos. Res. 2018, 214, 263-274. [CrossRef]

76. Roig Rodelas, R.; Chakraborty, A.; Perdrix, E.; Tison, E.; Riffault, V. Real-time assessment of wintertime organic aerosol characteristics and sources at a suburban site in northern France. Atmos. Environ. 2019, 203, 48-61. [CrossRef]

77. Gilardoni, S.; Massoli, P.; Paglione, M.; Giulianelli, L.; Carbone, C.; Rinaldi, M.; Decesari, S.; Sandrini, S.; Costabile, F.; Gobbi, G.P.; et al. Direct observation of aqueous secondary organic aerosol from biomass-burning emissions. Proc. Natl. Acad. Sci. USA 2016, 113, 10013-10018. [CrossRef] [PubMed]

78. Brege, M.; Paglione, M.; Gilardoni, S.; Decesari, S.; Facchini, M.C.; Mazzoleni, L.R. Molecular insights on aging and aqueousphase processing from ambient biomass burning emissions-influenced Po Valley fog and aerosol. Atmos. Chem. Phys. 2018, 18, 13197-13214. [CrossRef]

79. Reyes-Villegas, E.; Priestley, M.; Ting, Y.-C.; Haslett, S.; Bannan, T.; Le Breton, M.; Williams, P.I.; Bacak, A.; Flynn, M.J.; Coe, H.; et al. Simultaneous aerosol mass spectrometry and chemical ionisation mass spectrometry measurements during a biomass burning event in the UK: Insights into nitrate chemistry. Atmos. Chem. Phys. 2018, 18, 4093-4111. [CrossRef]

80. Young, D.E.; Allan, J.D.; Williams, P.I.; Green, D.C.; Harrison, R.M.; Yin, J.; Flynn, M.J.; Gallagher, M.W.; Coe, H. Investigating a two-component model of solid fuel organic aerosol in London: Processes, PM1 contributions, and seasonality. Atmos. Chem. Phys. 2015, 15, 2429-2443. [CrossRef]

81. Xu, L.; Williams, L.R.; Young, D.E.; Allan, J.D.; Coe, H.; Massoli, P.; Fortner, E.; Chhabra, P.; Herndon, S.; Brooks, W.A.; et al. Wintertime aerosol chemical composition, volatility, and spatial variability in the greater London area. Atmos. Chem. Phys. 2016, 16, 1139-1160. [CrossRef]

82. Srivastava, D.; Favez, O.; Petit, J.-E.; Zhang, Y.; Sofowote, U.M.; Hopke, P.K.; Bonnaire, N.; Perraudin, E.; Gros, V.; Villenave, E.; et al. Speciation of organic fractions does matter for aerosol source apportionment. Part 3: Combining off-line and on-line measurements. Sci. Total Environ. 2019, 690, 944-955. [CrossRef]

83. Charron, A.; Polo-Rehn, L.; Besombes, J.-L.; Golly, B.; Buisson, C.; Chanut, H.; Marchand, N.; Guillaud, G.; Jaffrezo, J.-L. Identification and quantification of particulate tracers of exhaust and non-exhaust vehicle emissions. Atmos. Chem. Phys. 2019, 19, 5187-5207. [CrossRef] 
84. LCSQA. Caractérisation Chimique et Étude de Sources des Particules en Martinique en 2018. Available online: https:/ /www.lcsqa. $\mathrm{org} / \mathrm{fr} /$ rapport/caracterisation-chimique-et-etude-de-sources-des-particules-en-martinique-en-2018 (accessed on 2 February 2021).

85. Aranke, O.; Algenaid, W.; Awe, S.; Joshi, S. Coatings for Automotive Gray Cast Iron Brake Discs: A Review. Coatings 2019, 9, 552. [CrossRef]

86. Gonzalez, R.O.; Strekopytov, S.; Amato, F.; Querol, X.; Reche, C.; Weiss, D. New Insights from Zinc and Copper Isotopic Compositions into the Sources of Atmospheric Particulate Matter from Two Major European Cities. Environ. Sci. Technol. 2016, 50, 9816-9824. [CrossRef]

87. Chatain, M.; Alvarez, R.; Ustache, A.; Rivière, E.; Favez, O.; Pallares, C. Simultaneous Roadside and Urban Background Measurements of Submicron Aerosol Number Concentration and Size Distribution (in the Range 20-800 nm), along with Chemical Composition in Strasbourg, France. Atmosphere 2021, 12, 71. [CrossRef]

88. Sarda-Estève, R.; Baisnée, D.; Guinot, B.; Sodeau, J.; O'Connor, D.; Belmonte, J.; Besancenot, J.-P.; Petit, J.-E.; Thibaudon, M.; Oliver, G.; et al. Variability and Geographical Origin of Five Years Airborne Fungal Spore Concentrations Measured at Saclay, France from 2014 to 2018. Remote Sens. 2019, 11, 1671. [CrossRef]

89. Sarda-Estève, R.; Baisnée, D.; Guinot, B.; Mainelis, G.; Sodeau, J.; O'Connor, D.; Besancenot, J.P.; Thibaudon, M.; Monteiro, S.; Petit, J.-E.; et al. Atmospheric Biodetection Part I: Study of Airborne Bacterial Concentrations from January 2018 to May 2020 at Saclay, France. IJERPH 2020, 17, 6292. [CrossRef] [PubMed]

90. Samaké, A.; Jaffrezo, J.-L.; Favez, O.; Weber, S.; Jacob, V.; Canete, T.; Albinet, A.; Charron, A.; Riffault, V.; Perdrix, E.; et al. Arabitol, mannitol, and glucose as tracers of primary biogenic organic aerosol: The influence of environmental factors on ambient air concentrations and spatial distribution over France. Atmos. Chem. Phys. 2019, 19, 11013-11030. [CrossRef]

91. Samaké, A.; Martins, J.M.F.; Bonin, A.; Uzu, G.; Taberlet, P.; Conil, S.; Favez, O.; Thomasson, A.; Chazeau, B. Variability of the atmospheric PM10 microbiome in three climatic regions of France. Front. Microbiol. 2020, 11, 576750. [CrossRef] [PubMed]

92. Bhugwant, C.; Bessafi, M.; Favez, O.; Chiappini, L.; Sieja, B.; Leoz-Garziandia, E. High Contribution of Sea Salt Aerosols on Atmospheric Particles Measured at an Urban Tropical Location in Reunion Island. JEP 2013, 4, 828-842. [CrossRef]

93. Taylor, D.A. Dust in the wind. Environ. Health Perspect. 2002, 110, A80-A87. [CrossRef] [PubMed]

94. Prospero, J.M. The atmospheric transport of particles to the ocean. In Particle Flux in the Ocean; John Wiley \& Sons Ltd.: Chichester, UK; New York, NY, USA, 1996; pp. 19-52.

95. Prospero, J.M.; Mayol-Bracero, O.L. Understanding the Transport and Impact of African Dust on the Caribbean Basin. Bull. Am. Meteor. Soc. 2013, 94, 1329-1337. [CrossRef]

96. Perez, L.; Tobias, A.; Querol, X.; Künzli, N.; Pey, J.; Alastuey, A.; Viana, M.; Valero, N.; González-Cabré, M.; Sunyer, J. Coarse Particles From Saharan Dust and Daily Mortality. Epidemiology 2008, 19, 800-807. [CrossRef]

97. Viel, J.-F.; Mallet, Y.; Raghoumandan, C.; Quénel, P.; Kadhel, P.; Rouget, F.; Multigner, L. Impact of Saharan dust episodes on preterm births in Guadeloupe (French West Indies). Occup. Environ. Med. 2019, 76, 336-340. [CrossRef]

98. LCSQA. Programme CARA-Bilan des Travaux. 2010. Available online: https://www.lcsqa.org/fr/node/1671/printable/pdf (accessed on 2 February 2021).

99. Quenel, P.; Vadel, J.; Garbin, C.; Durand, S.; Favez, O.; Albinet, A.; Raghoumandan, C.; Guyomard-Rabenirina, S.; Alleman, L.Y.; Mercier, F.L. PM10 chemical profile exposure to the French West Indies Guadeloupean population during Saharan dust episodes. Atmosphere. under review.

100. Michelot, N.; Endlicher, W.; Carrega, P.; Martin, N.; Favez, O.; Langner, M. Impact of a Saharan dust outbreak on PM10 ground levels in Southeastern France. Climatologie 2016. [CrossRef]

101. Bourgeois, I.; Savarino, J.; Caillon, N.; Angot, H.; Barbero, A.; Delbart, F.; Voisin, D.; Clément, J.-C. Tracing the Fate of Atmospheric Nitrate in a Subalpine Watershed Using $\Delta^{17}$ O. Environ. Sci. Technol. 2018, 52, 5561-5570. [CrossRef] [PubMed]

102. David Felix, J.; Elliott, E.M.; Gish, T.J.; McConnell, L.L.; Shaw, S.L. Characterizing the isotopic composition of atmospheric ammonia emission sources using passive samplers and a combined oxidation-bacterial denitrifier approach: Improved method for isotope characterization of ammonia in air. Rapid Commun. Mass Spectrom. 2013, 27, 2239-2246. [CrossRef] [PubMed]

103. Zhang, L.; Altabet, M.A.; Wu, T.; Hadas, O. Sensitive Measurement of NH4+ 15N/14N (d15NH4+) at Natural Abundance Levels in Fresh and Saltwaters. Anal. Chem. 2007, 79, 5297-5303. [CrossRef] [PubMed]

104. David Felix, J.; Elliott, E.M.; Gish, T.; Maghirang, R.; Cambal, L.; Clougherty, J. Examining the transport of ammonia emissions across landscapes using nitrogen isotope ratios. Atmos. Environ. 2014, 95, 563-570. [CrossRef]

105. Fortems-Cheiney, A.; Dufour, G.; Hamaoui-Laguel, L.; Foret, G.; Siour, G.; Van Damme, M.; Meleux, F.; Coheur, P.-F.; Clerbaux, C.; Clarisse, L.; et al. Unaccounted variability in NH3 agricultural sources detected by IASI contributing to European spring haze episode. Geophys. Res. Lett. 2016, 43, 5475-5482. [CrossRef]

106. LCSQA. Programme CARA: Bilan des Travaux 2014-2015. Available online: https://www.lcsqa.org/fr/rapport/programmecara-bilan-des-travaux-2018-2019 (accessed on 2 February 2021).

107. Wang, M.; Kong, W.; Marten, R.; He, X.-C.; Chen, D.; Pfeifer, J.; Heitto, A.; Kontkanen, J.; Dada, L.; Kürten, A.; et al. Rapid growth of new atmospheric particles by nitric acid and ammonia condensation. Nature 2020, 581, 184-189. [CrossRef]

108. Petetin, H.; Sciare, J.; Bressi, M.; Gros, V.; Rosso, A.; Sanchez, O.; Sarda-Estève, R.; Petit, J.-E.; Beekmann, M. Assessing the ammonium nitrate formation regime in the Paris megacity andits representation in the CHIMERE model. Atmos. Chem. Phys. 2016, 16, 10419-10440. [CrossRef] 
109. Petit, J.-E.; Favez, O.; Albinet, A.; Canonaco, F. A user-friendly tool for comprehensive evaluation of the geographical origins of atmospheric pollution: Wind and trajectory analyses. Environ. Model. Softw. 2017, 88, 183-187. [CrossRef]

110. Boichu, M.; Favez, O.; Riffault, V.; Petit, J.-E.; Zhang, Y.; Brogniez, C.; Sciare, J.; Chiapello, I.; Clarisse, L.; Zhang, S.; et al Large-scale particulate air pollution and chemical fingerprint of volcanic sulfate aerosols from the 2014-2015 Holuhraun flood lava eruption of Bárðarbunga volcano (Iceland). Atmos. Chem. Phys. 2019, 19, 14253-14287. [CrossRef]

111. Stein, A.F.; Draxler, R.R.; Rolph, G.D.; Stunder, B.J.B.; Cohen, M.D.; Ngan, F. NOAA's HYSPLIT Atmospheric Transport and Dispersion Modeling System. Bull. Am. Meteorol. Soc. 2015, 96, 2059-2077. [CrossRef]

112. Pay, M.T.; Jiménez-Guerrero, P.; Baldasano, J.M. Assessing sensitivity regimes of secondary inorganic aerosol formation in Europe with the CALIOPE-EU modeling system. Atmos. Environ. 2012, 51, 146-164. [CrossRef]

113. Chazeau, B.; Temime-Roussel, B.; Gille, G.; Mesbah, B.; D'Anna, B.; Wortham, H.; Marchand, N. Measurement Report: Long-Term Real-Time Characterisation of Thesubmicronic Aerosol and Its Atmospheric Dynamic in a Mediterraneancoastal City: Tracking the Polluted Events at the Marseille-Longchampsupersite. Aerosols/Field Measurements/Troposphere/Chemistry (Chemical Composition and Reactions). Available online: https://acp.copernicus.org/preprints/acp-2020-1015/ (accessed on 2 February 2021).

114. El Haddad, I.; D'Anna, B.; Temime-Roussel, B.; Nicolas, M.; Boreave, A.; Favez, O.; Voisin, D.; Sciare, J.; George, C.; Jaffrezo, J.-L.; et al. Towards a better understanding of the origins, chemical composition and aging of oxygenated organic aerosols: Case study of a Mediterranean industrialized environment, Marseille. Atmos. Chem. Phys. 2013, 13, 7875-7894. [CrossRef]

115. Kleindienst, T.E.; Jaoui, M.; Lewandowski, M.; Offenberg, J.H.; Lewis, C.W.; Bhave, P.V.; Edney, E.O. Estimates of the contributions of biogenic and anthropogenic hydrocarbons to secondary organic aerosol at a southeastern US location. Atmos. Environ. 2007, 41, 8288-8300. [CrossRef]

116. Albinet, A.; Lanzafame, G.M.; Srivastava, D.; Bonnaire, N.; Nalin, F.; Wise, S.A. Analysis and determination of secondary organic aerosol (SOA) tracers (markers) in particulate matter standard reference material (SRM 1649b, urban dust). Anal. Bioanal. Chem. 2019, 411, 5975-5983. [CrossRef]

117. Lanzafame, G.M.; Srivastava, D.; Favez, O.; Bandowe, B.A.M.; Shahpoury, P.; Lammel, G.; Bonnaire, N.; Alleman, L.Y.; Couvidat, F.; Bessagnet, B.; et al. One-year measurements of secondary organic aerosol (SOA) markers in the Paris region (France): Concentrations, gas/particle partitioning and SOA source apportionment. Sci. Total Environ. 2021, 757, 143921. [CrossRef] [PubMed]

118. Srivastava, D.; Daellenbach, K.R.; Zhang, Y.; Bonnaire, N.; Chazeau, B.; Perraudin, E.; Gros, V.; Lucarelli, F.; Villenave, E.; Prévôt, A.S.H.; et al. Comparison of five methodologies to apportion organic aerosol sources during a PM pollution event. Sci. Total Environ. 2021, 757, 143168. [CrossRef]

119. Zhang, Q.; Jimenez, J.L.; Canagaratna, M.R.; Allan, J.D.; Coe, H.; Ulbrich, I.; Alfarra, M.R.; Takami, A.; Middlebrook, A.M.; Sun, Y.L.; et al. Ubiquity and dominance of oxygenated species in organic aerosols in anthropogenically-influenced Northern Hemisphere midlatitudes. Geophys. Res. Lett. 2007, 34. [CrossRef]

120. Crippa, M.; Canonaco, F.; Slowik, J.G.; El Haddad, I.; DeCarlo, P.F.; Mohr, C.; Heringa, M.F.; Chirico, R.; Marchand, N.; TemimeRoussel, B.; et al. Primary and secondary organic aerosol origin by combined gas-particle phase source apportionment. Atmos. Chem. Phys. 2013, 13, 8411-8426. [CrossRef]

121. Daellenbach, K.R.; El-Haddad, I.; Karvonen, L.; Vlachou, A.; Corbin, J.C.; Slowik, J.G.; Heringa, M.F.; Bruns, E.A.; Luedin, S.M.; Jaffrezo, J.-L.; et al. Insights into organic-aerosol sources via a novel laser-desorption/ionization mass spectrometry technique applied to one year of PM10 samples from nine sites in central Europe. Atmos. Chem. Phys. 2018, 18, 2155-2174. [CrossRef]

122. Tremper, A.H.; Font, A.; Priestman, M.; Hamad, S.H.; Chung, T.-C.; Pribadi, A.; Brown, R.J.C.; Goddard, S.L.; Grassineau, N.; Petterson, K.; et al. Field and laboratory evaluation of a high time resolution x-ray fluorescence instrument for determining the elemental composition of ambient aerosols. Atmos. Meas. Technol. 2018, 11, 3541-3557. [CrossRef] 